HENRIQUE WANDERLEY

\title{
A PERCEPÇÃO DOS HÓSPEDES QUANTO AOS ATRIBUTOS OFERECIDOS PELOS HOTÉIS VOLTADOS PARA O TURISMO DE NEGÓCIOS NA CIDADE DE SÃO PAULO
}

Dissertação apresentada à Escola Politécnica da Universidade de São Paulo para obtenção do Título de Mestre em Engenharia. 
HENRIQUE WANDERLEY

\section{A PERCEPÇÃO DOS HÓSPEDES QUANTO AOS ATRIBUTOS OFERECIDOS PELOS HOTÉIS VOLTADOS PARA O TURISMO DE NEGÓCIOS NA CIDADE DE SÃO PAULO}

Dissertação apresentada à Escola Politécnica da Universidade de São Paulo para obtenção do Título de Mestre em Engenharia.

Área de Concentração:

Engenharia Civil

Orientador:

Prof $^{a}$. Doutora

Eliane Monetti 


\section{AGRADECIMENTOS}

Neste momento especial gostaria de agradecer a todos as pessoas que, direta ou indiretamente, colaboraram na execução desta pesquisa e que, mesmo não citadas nesta página, merecem minha sincera gratidão.

À Prof ${ }^{a}$. Dr. ${ }^{a}$ Eliane Monetti pela orientação e solicitude.

À minha mãe, Isabel, pelos cuidados e permanente incentivo.

Ao meu pai, Manoel, pelos conhecimentos e referência.

Ao meu irmão, Márcio, pela compreensão e amizade.

Aos meus amigos pelo convívio social e momentos de alegria.

Aos estabelecimentos hoteleiros, através dos seus gerentes, pela grande colaboração durante o processo de coleta de dados para a execução desta pesquisa.

À todas as pessoas que responderam aos questionários da pesquisa de campo, pela paciência e valiosa colaboração.

À Promon, fonte de imensurável conhecimento, pelo apoio e ambiente de amizade com os colegas de trabalho. 


\section{RESUMO}

Esta pesquisa é resultado do reconhecimento, no mercado hoteleiro, de algumas vantagens em se conhecer o conjunto de necessidades específicas de um determinado tipo de hóspede. O turismo de negócios é visto como um importante segmento do mercado turístico e como forte gerador da demanda hoteleira em algumas regiões. A proposta é, a partir da apresentação de características do mercado turístico e do setor hoteleiro, discutir a percepção do turista de negócios quanto aos atributos oferecidos pelos hotéis que justificam a preferência por dado empreendimento para sua estadia. A pesquisa bibliográfica, aliada a um estudo exploratório na cidade de São Paulo, permite algumas conjecturas a respeito do comportamento do turista de negócios no que diz respeito à hospedagem. Em virtude do dinamismo desta demanda, espera-se incentivar com esta pesquisa a continuidade, por profissionais e acadêmicos, dos estudos a respeito do mercado hoteleiro para o turismo de negócios. 


\begin{abstract}
This research is the outcome of the recognition, in the hotel market, of the advantages of knowing the needs of a certain guest profile. Business tourism is an important segment of the tourism market and generates a great demand in some specific regions. The purpose of the research is, from the overview of the characteristics of tourism market and hotels segment, discuss the business tourist perspective of the attributes offered by hotels that justify their preference for a specific project. Research bibliography combined with an exploration in the city of São Paulo, allowed some hypothesis regarding business tourist behavior concerning hosting. Due to the dynamism of hotel demand, is expected that professionals and academics be stimulated to prospect and study the hotel market for business tourism.
\end{abstract}




\section{SUMÁRIO}

\section{LISTA DE FIGURAS}

\section{LISTA DE TABELAS}

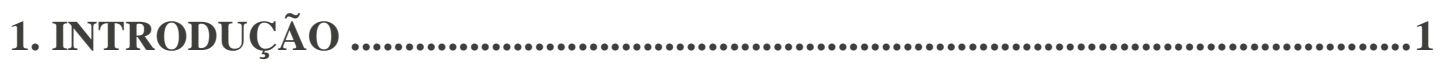

1.1 Definição do problema ............................................................................ 1

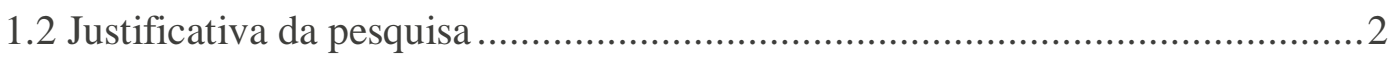

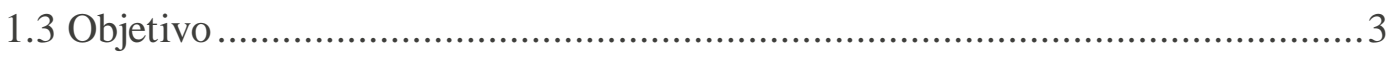

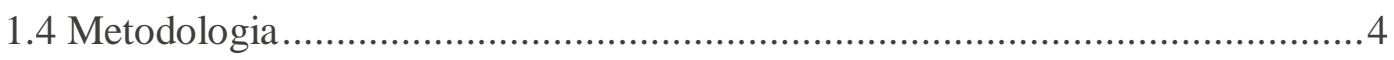

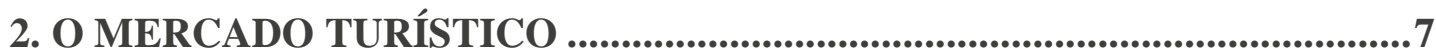

2.1 Caracterização do turismo ...................................................................... 7

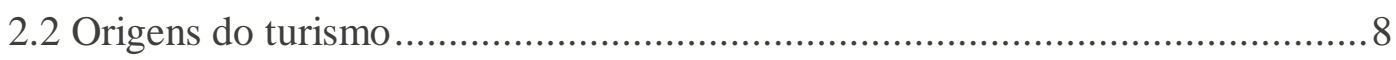

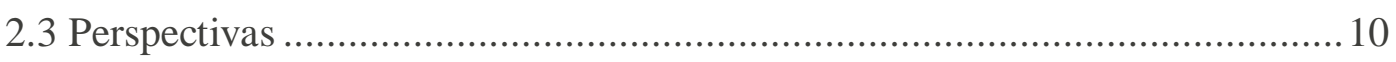

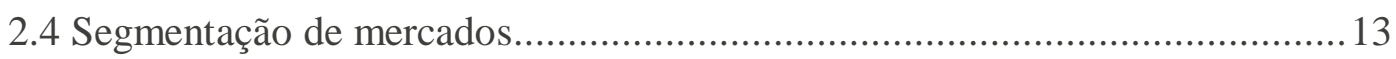

2.5 Segmentação do mercado turístico ..................................................... 17

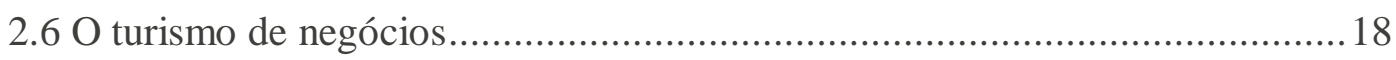

3. O SETOR HOTELEIRO_.............................................................................22

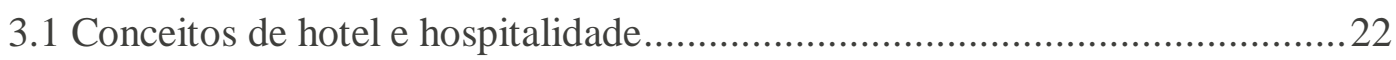

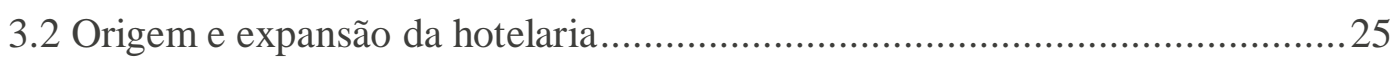

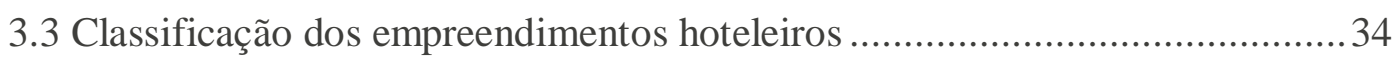

3.4 A influência da economia no setor hoteleiro ............................................4 43

4. INSTALAÇÕES E SERVIÇOS DO HOTEL ............................................46

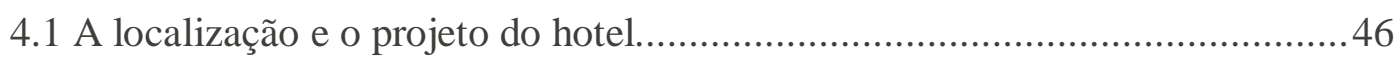

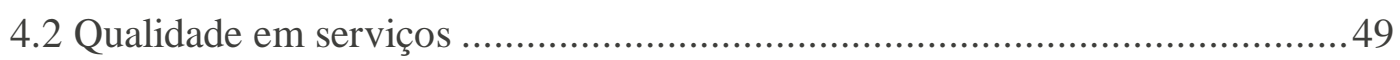

4.3 Características dos serviços de hotelaria...................................................50

$4.4 \mathrm{O}$ atendimento ao turista de negócios .....................................................54

5. PESQUISA DE CAMPO NA CIDADE dE SÃO PAULO ..............................58

$5.1 \mathrm{O}$ perfil da demanda hoteleira em São Paulo ..............................................58

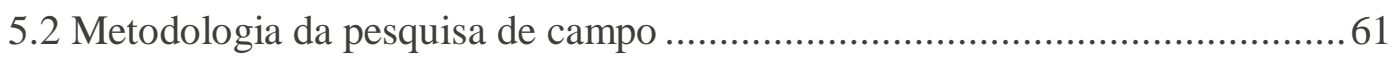

6. ANÁLISE DOS RESULTADOS DA PESQUISA .........................................73

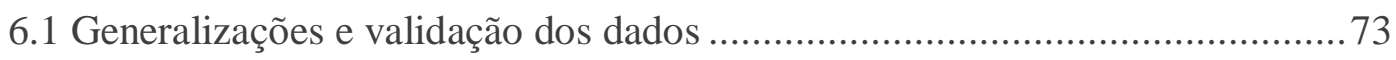

6.2 Apresentação e discussão dos resultados ................................................. 74 


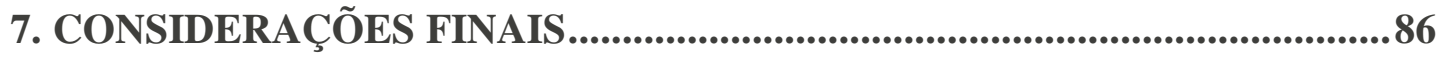

REFERÊNCIAS BIBLIOGRÁFICAS............................................................90

BIBLIOGRAFIA CONSULTADA .................................................................95

ANEXO A: Questionário aplicado aos hóspedes nos hotéis

ANEXO B: Questionário aplicado via e-mail 


\section{LISTA DE FIGURAS}

Figura 1 - Locais dos eventos em São Paulo

Figura 2 - Regiões de concentração de hotéis e escritórios em São Paulo .63

Figura 3 - Estágios principais de um Levantamento. .69

Figura 4 - Quantas vezes esteve em São Paulo anteriormente. .76

Figura 5 - Quanto tempo permaneceu ou permanecerá na cidade. .77

Figura 6 - Grau de importância dos fatores decisivos para a escolha do hotel. .78

Figura 7 - Médias dos fatores decisivos para a escolha do hotel .79

Figura 8 - Fatores importantes na localização do hotel. 81

Figura 9 - Equipamentos/Serviços que espera encontrar no hotel. .82

Figura 10 - Como se sente com as opções de hospedagem em São Paulo. .83

Figura 11 - Fatores que motivariam a voltar ao hotel. .84 


\section{LISTA DE TABELAS}

Tabela 1 - Chegada de Turistas no Mundo, América do Sul e Brasil.

Tabela 2 - Receita Gerada pelos Turistas no Mundo, América do Sul e Brasil.........12

Tabela 3 - Marcos da hotelaria no Mundo. .26

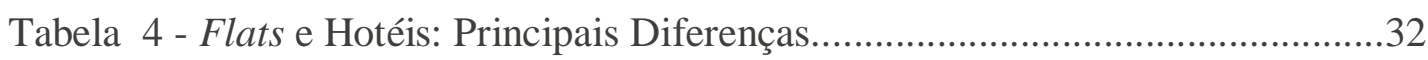

Tabela 5 - A escolha do hotel: turismo de negócios em São Paulo. .55

Tabela 6 - O que prejudica um hotel: turismo de negócios em São Paulo. .56

Tabela 7 - Relação dos hotéis participantes da pesquisa. .66

Tabela 8 - Relação dos hotéis avaliados na pesquisa via $e$-mail. 68 


\section{INTRODUÇÃO}

\subsection{Definição do problema}

O turismo impacta diversos segmentos diferentes da economia brasileira, empregando em sua cadeia desde mão-de-obra mais qualificada, em áreas que se utilizam de alta tecnologia, até as de menor qualificação, tanto no emprego formal quanto no informal. Desta maneira, o turismo apresenta-se como uma atividade econômica de grande importância para o Brasil e o seu potencial de crescimento pode trazer oportunidades para o mercado hoteleiro.

A análise e a avaliação das atividades do mercado hoteleiro para o turismo não são tarefas simples em virtude do grande número de variáveis que compõem o sistema hoteleiro.

O que se nota no país ultimamente é que o setor hoteleiro, muitas vezes, tem concentrado suas atenções na maximização de vendas de unidades habitacionais ${ }^{1}$, ou na obtenção de recursos econômicos, ao invés de tentar solucionar os problemas de hospedagem para determinado tipo de hóspede, e de como satisfazer a um conjunto de necessidades desses hóspedes. Nestes casos, o objetivo é a obtenção dos resultados através do maior volume de vendas possível.

Como exemplo desse quadro temos a pequena e média hotelaria do país que, limitadas pelas qualidades reduzidas de instalações e organização, reivindicam constantemente por recursos econômicos e incentivos fiscais junto ao governo, mas que ainda não reconheceram as enormes dificuldades em atender a todas as manifestações das necessidades dos mais diversos tipos de hóspedes. Ou seja, há uma certa resistência em reconhecer a existência de segmentos de mercado dentro de cada mercado. O reconhecimento das limitações de seus recursos deveria levar estas empresas hoteleiras a impor limitações adicionais em suas operações potenciais.

1. Segundo a Deliberação Normativa n. 429 (EMBRATUR, 2002a), entende-se por Unidade Habitacional (UH) o espaço, atingível a partir das áreas principais de circulação comuns do estabelecimento, destinado à utilização pelo hóspede, para seu bem-estar, higiene e repouso. 
Como em qualquer outro setor da economia, é fundamental para a indústria hoteleira analisar as oportunidades de mercado, para que desta forma possam ser definidas metas e objetivos específicos, e formuladas diretrizes operacionais para as empresas. Merrit; Berger (1998) destacam a importância de se estabelecer metas e objetivos como forma de definir o caminho a ser percorrido e, então, gerenciar de maneira adequada os recursos da empresa.

\subsection{Justificativa da pesquisa}

A segmentação de mercado é, freqüentemente, definida como uma estratégia de marketing. Em uma dimensão mais ampla, ela pode ser considerada como um processo que conduz a empresa à escolha entre estratégias alternativas e, não raramente, pode ser utilizada como uma verdadeira arma concorrencial.

No mercado turístico, durante os últimos anos, as empresas têm percebido que uma única estratégia já não consegue atender àqueles que buscam produtos específicos. Surge, então, a necessidade de segmentar o mercado. O aumento da concorrência nos mais diversos segmentos é um fator determinante para a segmentação, levando maior vantagem nas vendas a empresa que melhor conhecer o seu mercado potencial, podendo, desta maneira, direcionar seus recursos financeiros e adequar os seus produtos a esse mercado.

No mercado hoteleiro, não existem dois hotéis iguais nem instalados no mesmo lugar; ou seja, o que um oferece, o outro não o fará exatamente da mesma maneira. Porém esse poder de mercado é de alcance reduzido, pois mesmo não havendo hotéis exatamente iguais, há os semelhantes, e mesmo que o consumidor esteja disposto a pagar um pouco mais pelo seu produto preferido, caso o preço suba muito ele deixará de lado suas preferências e irá se alojar no hotel concorrente.

Neste sentido, a segmentação de mercado pode, além de auxiliar as empresas hoteleiras a limitar e melhor estruturar suas operações potenciais, limitando desta forma a necessidade de recursos para ampliação e modernização de sua capacidade 
de hospedagem, aumentar o potencial de concorrência, permitindo uma organização baseada no conhecimento mais detalhado do seu hóspede.

Dados divulgados pela EMBRATUR (2002c) apontam que o turismo resultante das viagens motivadas por interesses comerciais, negócios e convenções foi o que mais cresceu no Brasil na última década. Segundo Andrade (2000), a internacionalização dos mercados e o desenvolvimento mundial dos negócios são os fatores que mais contribuem para o desenvolvimento do turismo de negócios.

Este é um segmento de mercado que possui diferentes necessidades e expectativas em relação ao turismo de lazer, o que gera uma necessidade de remodelação da oferta dos meios de hospedagem visando ao crescente número de profissionais que se deslocam para realização de suas atividades econômicas.

Esta pesquisa discute o mercado hoteleiro para o turismo de negócios, destacando a segmentação como forma de estratificar grupos distintos de hóspedes, facilitando desta maneira a identificação e a análise de algumas das principais características daqueles que compõem a demanda pelos "hotéis de negócios". O reconhecimento e a caracterização desta demanda são etapas fundamentais no processo de concepção dos empreendimentos, sendo igualmente úteis em análises mercadológicas que podem fornecer informações valiosas a respeito da adequação da oferta hoteleira ao atendimento a este tipo de hóspede.

\subsection{Objetivo}

O objetivo específico da pesquisa é caracterizar o mercado formado pelo turismo de negócios para hospedagem através do reconhecimento da percepção das pessoas que viajam por motivos profissionais quanto aos atributos oferecidos pelo hotel, e que justificam a preferência por um dado empreendimento para sua estadia.

A cidade de São Paulo, reconhecidamente um grande centro de negócios, é alvo, nesta pesquisa, de um estudo exploratório. A oferta hoteleira da cidade é tomada 
como meio para se coletar dados e promover discussões a respeito da adequação de um segmento do mercado hoteleiro a um tipo específico de hóspede.

Um outro objetivo desta pesquisa é auxiliar profissionais e pesquisadores do setor hoteleiro na identificação de um segmento de mercado com grande potencial no país, e discutir os atributos que devem ser observados durante a concepção e a operação de um empreendimento hoteleiro que visa ao atendimento do turista de negócios.

Espera-se também que esta pesquisa sirva de ponto de partida para outras sobre o tema, uma vez que a demanda, em sua contínua evolução, sofre grandes e significativas transformações.

\subsection{Metodologia}

Para atingir o objetivo proposto, esta pesquisa foi estruturada em quatro grandes etapas.

$\mathrm{Na}$ primeira delas, foi realizada a coleta de informações a respeito dos mercados turístico e hoteleiro, através de consulta em livros, jornais, revistas, periódicos, boletins técnicos, trabalhos acadêmicos e sites na internet, consolidando-se uma base conceitual para o início dos trabalhos. O objetivo desta etapa foi, sobretudo, reunir bibliografia suficiente para uma definição clara e objetiva do ambiente de discussão da pesquisa. Desta forma, foram investigados aspectos relativos ao comportamento do mercado turístico, envolvendo tanto sua formação ao longo do tempo como o seu entendimento atual. Do mesmo modo, o setor hoteleiro foi explorado, e caracterizado, de maneira a permitir um entendimento do mercado que facilitasse a discussão a respeito de um dos seus segmentos.

Toda a estruturação e discussão do material coletado fazem parte de uma segunda etapa da pesquisa, onde o foco estava na organização das informações. O objetivo foi instituir o ambiente de estudo de forma gradativa e sequiencial, culminando em uma discussão mais detalhada sobre o segmento do mercado hoteleiro que busca o 
atendimento das necessidades e anseios do turista de negócios. Vale ressaltar que, inevitavelmente, houve uma sobreposição com a primeira etapa, caracterizando um processo contínuo de busca de informações, que, neste segundo momento, encontrava-se mais focado nos setores do turismo e da hotelaria voltados especialmente aos negócios.

Com o objetivo de coletar informações a respeito do turista de negócios, realizou-se uma pesquisa de campo na cidade de São Paulo. É importante destacar a intenção de evidenciar o comportamento do turista de negócios no que se refere à hospedagem. Não se trata de um estudo específico sobre o mercado hoteleiro da cidade de São Paulo, e sim da utilização deste mercado para se reconhecer um comportamento de consumo. A escolha da cidade de São Paulo como amostra para esta investigação se deu por ser esta uma cidade com vocação comprovada para os negócios, ou seja, onde há grande quantidade de pessoas a negócios todos os dias.

A pesquisa de campo consistiu na aplicação de um questionário aos turistas que estavam a negócios na cidade. Este questionário foi elaborado com a intenção de se reconhecer a percepção do turista que está em viagem de negócios com relação aos atributos oferecidos pelos hotéis. A aplicação do questionário foi feita de duas maneiras distintas: no próprio hotel, através da disponibilização dos questionários aos hóspedes, e via internet, onde o questionário, adaptado a uma planilha eletrônica, foi distribuído através de e-mails a alguns turistas que estavam na cidade de São Paulo, porém não necessariamente nos hotéis no momento do recebimento do questionário.

A quarta e última etapa do estudo envolve a discussão dos resultados da pesquisa de campo. Nesta etapa, é feita uma análise da percepção dos hóspedes quanto aos atributos oferecidos pelos hotéis. As considerações finais da pesquisa podem ser enquadradas como parte integrante desta etapa, uma vez que é resultado direto da discussão a respeito dessa adequação. 
Vale ressaltar que estas etapas não estão apresentadas no estudo de forma seqüencial, tal como aconteceram. O trabalho está estruturado de forma a facilitar a compreensão de sua discussão principal, entendimento este que norteou a sequiência de apresentação dos resultados de cada etapa da pesquisa.

Em resumo, as duas primeiras etapas foram dedicadas à coleta e estruturação de informações que possibilitaram um entendimento adequado do ambiente de discussão da pesquisa, tanto do mercado turístico como do mercado hoteleiro. Um dos destaques nessas etapas foi a discussão a respeito da importância do processo de segmentação na identificação de um nicho específico de mercado. A pesquisa de campo, terceira etapa, veio completar as lacunas deixadas na caracterização da demanda, ou seja, do turista de negócios, e complementar o estudo de maneira a permitir a discussão proposta na quarta etapa deste trabalho. 


\section{O MERCADO TURÍSTICO}

O turismo é a atividade responsável pelo surgimento e desenvolvimento dos meios de hospedagem em todo o mundo.

O fenômeno do turismo será discutido aqui segundo a visão de alguns autores, destacando a sua importância como atividade interdisciplinar que incide econômica, social e culturalmente em nossa sociedade.

O objetivo fundamental do capítulo é, através da aplicação do critério de segmentação de mercado, caracterizar o turismo de negócios, ressaltando suas particularidades e o seu papel como ambiente de desenvolvimento dos hotéis de negócios.

\subsection{Caracterização do turismo}

Segundo Lage; Milone (2000b), o turismo no passado era entendido como as viagens para regiões distantes mais de cinqüenta milhas dos locais de residência dos turistas, ou ainda, que exigissem a permanência dos viajantes por mais de 24 horas no lugar visitado. Além disso, era importante que o turista não exercesse, nessa localidade, atividade remunerada. Esses conceitos não mais se sustentam nos dias atuais.

É muito difícil hoje limitar uma definição específica de turismo. Por estabelecer múltiplas relações com as mais diversas áreas de conhecimento como geografia, história, economia, sociologia e direito, o turismo pode ser entendido de várias formas, sendo concebido segundo critérios e interesses próprios. O fato é que o turismo não deve mais ser entendido como atividade voltada exclusivamente para o lazer e sim de uma forma mais global, considerando sua importância econômica, social e cultural na sociedade. 
Desta forma mais abrangente, Mathieson; Wall (1990) definem o turismo como sendo o movimento temporário de pessoas para locais de destinos distintos de seus lugares de trabalho e moradia, incluindo também as atividades exercidas durante a permanência desses viajantes nos locais de destino e as facilidades para promover suas necessidades.

Porém, a definição mais objetiva, e que melhor se adapta aos propósitos desta pesquisa, é a de Santana, na qual o autor define o turismo como sendo um sistema de serviços que tem como finalidade única e exclusiva, o planejamento, a promoção e a execução de viagens, além da existência de infra-estrutura adequada para recepção, hospedagem, consumo e atendimento às pessoas e/ou grupos, oriundos de suas localidades residenciais (informação verbal) ${ }^{2}$. Com esta definição, o autor caracteriza o turismo dos dias atuais, sem a exclusão de qualquer propósito que possa ter motivado a viagem e considerando todas as facilidades que o turista busca para satisfazer as suas necessidades, incluindo assim as atividades desenvolvidas durante a permanência no local visitado.

\subsection{Origens do turismo}

$\mathrm{O}$ fator viagem pode ser considerado como atividade comum à maioria dos povos do mundo, podendo ser colocado como necessidade de deslocamento pelos mais diversos motivos, desde as conquistas (guerras e invasões) até o lazer e os negócios.

Segundo a historiografia, datam da Antiguidade Clássica, sobretudo dos gregos e romanos, os primeiros registros de deslocamentos constantes para os mais diversos fins, incluindo espetáculos culturais, festivais, jogos, finalidades religiosas, entre muitos outros. Um marco para a modelagem e representação turística mais organizada foi a fase renascentista, pois o incentivo à ciência e às artes provocou

2 Informação fornecida por Carlos José de Almeida Santana, Mestre em Geografia e professor da disciplina Geografia e Espaço do Turismo na Faculdade Castro Alves (FCA) durante seminário em 1999 na própria FCA. 
uma revolução nos hábitos dos europeus, que passaram a utilizar as viagens como forma de explorar novos lugares.

Entretanto, o grande divisor de águas na história da humanidade foi a Revolução Industrial ocorrida na segunda metade do século XVIII, na Inglaterra. Foi nessa época que houve verdadeiras e definitivas transformações na qualidade de vida e, acima de tudo, nos meios de comunicação e transportes, tornando mais rápidas as viagens e oferecendo mais tranqüilidade, conforto e proteção para os viajantes.

A história do turismo, nos moldes atuais, começa, efetivamente, na segunda metade do século XIX, quando foram organizadas as primeiras atividades turísticas, devido à intervenção de personalidades exponenciais da Europa, sobretudo da sociedade inglesa, tais como Thomas Cook e Cesar Ritz. Thomas Cook foi o primeiro empreendedor a efetivar uma viagem eminentemente turística, fretando um trem, que transportou cerca de 570 pessoas, para um Congresso Antialcoólico, organizado por evangélicos, em 1841, nas cidades de Leicester e Loughborough, na Inglaterra (Andrade, 2000).

As invenções do automóvel e do avião no século $\mathrm{XX}$ foram inovações que viabilizaram deslocamentos mais constantes e independentes de um maior número de pessoas, mesmo sendo o segundo, apesar da rapidez e do conforto, um meio de transporte mais restrito devido ao valor das passagens.

Em 1947, durante o II Congresso de Organismos Nacionais de Turismo, na França, foi fundada a União Internacional dos Organismos Oficiais de Turismo (UIOOT), com o objetivo de divulgar e promover as empresas que operavam no sistema turístico mundial. Já na década de 1970, na cidade do México, durante a XXI Assembléia Geral da Organização das Nações Unidas (ONU), esta instituição passou a chamar-se Organização Mundial do Turismo (OMT). Um pouco antes, em 1967, esta entidade havia ganho a condição de Organismo Internacional, vinculada à própria ONU. 
A partir daí, começaram a ocorrer mais investimentos no setor turístico em todo o mundo.

Particularmente no continente americano, no ano de 1948, foi criada a Organização do Estados Americanos (OEA), envolvendo diversos países das três partes da América (Cuba, apesar de ser um dos países latino-americanos que tem um excelente fluxo turístico, foi expulso da entidade em 1962, por pressão norte-americana, em função de ter aderido ao regime socialista soviético em 1959).

A OEA possui, em sua estrutura, um setor denominado Divisão de Fomento ao Turismo, vinculado à Secretaria Geral da entidade, tendo como principal função promover e organizar congressos, simpósios, reuniões e seminários ligados ao desenvolvimento e dinamização da indústria turística, agindo como um órgão fomentador de projetos direcionados ao setor em análise, via Banco Interamericano de Desenvolvimento (BID) e Banco Mundial (conhecido como Banco Internacional para a Reconstrução e o Desenvolvimento-BIRD).

\subsection{Perspectivas}

Segundo Lage; Milone (2000a), o turismo é, sem dúvida alguma, uma atividade socioeconômica, na medida em que gera a produção de bens e serviços para o homem visando à satisfação de diversas necessidades básicas e secundárias. Complementam ainda observando o turismo atual como "uma rica e grandiosa indústria que se relaciona com todos os setores da economia mundial e que deverá continuar atendendo aos interesses da humanidade nos próximos milênios."

O fato é que, nos últimos anos, o mundo vem assistindo a um expressivo aumento do turismo. Este crescimento pode ser justificado basicamente por duas razões. A primeira é a necessidade das pessoas de conhecerem novos lugares e culturas, fugindo dessa maneira do estresse provocado pela vida nos centros urbanos. A segunda são os impactos positivos verificados na economia das localidades 
receptoras de turismo. Um exemplo disso é o fato do turismo ser o maior empregador do mundo. Segundo dados da Organização Mundial do Turismo (OMT) referentes à década de 90, são aproximadamente 204 milhões de pessoas trabalhando com o turismo, ou seja, um em cada nove trabalhadores do mundo está envolvido com a atividade turística. Assim, justifica-se o fato de países, estados e municípios, através da união de organismos públicos com a iniciativa privada, apresentarem grande interesse na busca de alternativas de desenvolvimento da atividade turística.

A fim de ilustrar o tamanho da movimentação gerada pelo turismo no mundo, e a sua evolução nos últimos anos, as Tabelas 1 e 2 a seguir apresentam, respectivamente, a chegada de turistas e a receita cambial gerada pelo turismo no mundo, na América do Sul e no Brasil entre os anos de 1992 e 2001.

Tabela 1 - Chegada de Turistas no Mundo, América do Sul e Brasil

\begin{tabular}{|c|r|r|r|r|r|r|}
\hline \multirow{2}{*}{ Ano } & \multicolumn{7}{|c|}{ Chegada de Turistas (em milhões de turistas) } \\
\cline { 2 - 7 } & No Mundo & $\begin{array}{c}\text { Incremento } \\
\text { no ano (\%) }\end{array}$ & $\begin{array}{c}\text { Na América } \\
\text { do Sul }\end{array}$ & $\begin{array}{c}\text { Incremento } \\
\text { no ano (\%) }\end{array}$ & No Brasil & $\begin{array}{c}\text { Incremento } \\
\text { no ano (\%) }\end{array}$ \\
\hline 1992 & 503,4 & - & 10,4 & - & 1,7 & - \\
\hline 1993 & 519,0 & 3,10 & 11,5 & 10,58 & 1,6 & $-5,88$ \\
\hline 1994 & 550,5 & 6,07 & 10,8 & $-6,09$ & 1,9 & 18,75 \\
\hline 1995 & 565,5 & 2,72 & 11,8 & 9,26 & 2,0 & 5,26 \\
\hline 1996 & 596,5 & 5,48 & 12,9 & 9,32 & 2,7 & 35,00 \\
\hline 1997 & 610,5 & 2,35 & 13,5 & 4,65 & 2,8 & 3,70 \\
\hline 1998 & 626,6 & 2,64 & 15,5 & 14,81 & 4,8 & 71,43 \\
\hline 1999 & 650,2 & 3,77 & 15,1 & $-2,58$ & 5,1 & 6,25 \\
\hline 2000 & 697,3 & 7,24 & 15,5 & 2,65 & 5,3 & 3,92 \\
\hline 2001 & 688,6 & $-1,25$ & 14,4 & $-7,10$ & 4,8 & $-9,43$ \\
\hline
\end{tabular}

Fonte: Organização Mundial do Turismo - OMT 
Tabela 2 - Receita Gerada pelos Turistas no Mundo, América do Sul e Brasil

\begin{tabular}{|r|r|r|r|r|r|r|}
\hline \multirow{2}{*}{ Ano } & \multicolumn{7}{|c|}{ Receita (em US\$ bilhões) } \\
\cline { 2 - 7 } & No Mundo & $\begin{array}{c}\text { Incremento } \\
\text { no ano (\%) }\end{array}$ & $\begin{array}{c}\text { Na América } \\
\text { do Sul }\end{array}$ & $\begin{array}{c}\text { Incremento } \\
\text { no ano (\%) }\end{array}$ & No Brasil & $\begin{array}{c}\text { Incremento } \\
\text { no ano (\%) }\end{array}$ \\
\hline 1992 & 305,8 & - & 7,3 & - & 1,3 & - \\
\hline 1993 & 321,5 & 5,14 & 8,5 & 16,44 & 1,1 & $-15,38$ \\
\hline 1994 & 354,0 & 10,12 & 8,3 & $-2,35$ & 1,9 & 72,73 \\
\hline 1995 & 405,1 & 14,44 & 9,3 & 12,05 & 2,1 & 10,53 \\
\hline 1996 & 435,6 & 7,53 & 10,7 & 15,05 & 2,5 & 19,05 \\
\hline 1997 & 436,0 & 0,09 & 11,4 & 6,54 & 2,6 & 4,00 \\
\hline 1998 & 442,5 & 1,49 & 11,8 & 3,51 & 3,7 & 42,31 \\
\hline 1999 & 455,0 & 2,82 & 11,6 & $-1,69$ & 4,0 & 8,11 \\
\hline 2000 & 477,9 & 5,03 & 12,2 & 5,17 & 4,2 & 5,00 \\
\hline 2001 & 472,0 & $-1,23$ & 11,3 & $-7,38$ & 3,7 & $-11,90$ \\
\hline
\end{tabular}

Fonte: Organização Mundial do Turismo - OMT

Os dados acima foram divulgados pela EMBRATUR (2002c) em uma coletânea que reúne as informações produzidas pelas principais fontes que divulgam regularmente dados de interesse do turismo, cobrindo um período de dez anos. Por esta razão, os dados fornecidos limitam-se ao ano de 2001.

Pode-se observar através desses dados que a América do Sul e, em especial, o Brasil, quando comparados com o mundo, são muito pouco representativos.

A razão desta parcela pouco significativa que representa a América do Sul perante o mundo com relação ao turismo foi justificada de forma direta pelo Prof. Dr. Mário Carlos Beni ${ }^{3}$ em uma apresentação sobre as perspectivas para o turismo no futuro próximo: "Acreditamos que as dificuldades e obstáculos que estão a determinar um crescimento lento e descontrolado do turismo nos países sul-americanos podem ser atribuídos à instabilidade político-institucional, às crescentes oscilações da conjuntura econômica produzindo ora inflação, ora recessão que castigam as esperanças nacionais e frustram os interesses da sociedade".

3 Apresentação feita pelo Prof. Dr. Mário Carlos Beni, professor titular da Escola de Comunicações e Artes da Universidade de São Paulo, em Junho de 2000, no Centro de Convenções da Gazeta Mercantil na cidade de São Paulo. 


\subsection{Segmentação de mercados}

Nesta pesquisa, o conceito de mercado será interpretado de uma maneira mais prática, sem os refinamentos empregados pelos estudiosos de marketing. Assim, um mercado é entendido aqui como sendo o conjunto de três fatores: pessoas com necessidades, o seu poder aquisitivo e o seu comportamento de compra e de uso. Acredita-se que este entendimento seja suficiente para os fins deste estudo.

Segundo Toledo (1972), a segmentação fundamenta-se no fato de que o mercado para determinado produto raramente é homogêneo em relação aos anseios e necessidades de quem o compõem, ou seja, nenhum produto pode ser todas as coisas para todos os consumidores durante todo o tempo. O motivo é que os consumidores são muitos, dispersos em diversas regiões, têm hábitos de compra variados, gostos diferenciados e variam em suas necessidades e preferências. Assim sendo, não se pode tratar todos da mesma forma, bem como não se pode tratar todos de forma diferente. $\mathrm{O}$ que se pode fazer é tentar reunir grupos de pessoas com características, preferências e gostos semelhantes, e trata-los como se fossem iguais.

Desta forma, a segmentação, antes de tudo, objetiva determinar diferenças entre grupos de compradores, separando-os em estratos, de forma a permitir a escolha daqueles onde concentrará seus esforços, determinando assim uma política competitiva.

Segundo Kotler (1992), a segmentação de mercado começa não com a distinção de possibilidades de produto, mas sim com a distinção de interesses ou de necessidades de clientes. A segmentação, segundo Kotler, é a subdivisão do mercado em subconjuntos homogêneos de clientes, em que qualquer subconjunto pode ser selecionado como meta de mercado para a empresa.

Uma das etapas mais difíceis do processo é justamente a escolha das características que melhor representam o comportamento dos consumidores em relação a um certo produto. O grande desafio é escolher um conjunto de características que represente 
um grupo de consumidores com um mínimo de diferenças entre si, porém com um máximo de diferenças com relação aos outros grupos.

A existência de diferenças significativas entre os consumidores em termos de gostos, desejos, necessidades, personalidade, comportamento, características geográficas e sócio-econômicas, determinam diferentes sistemas de consumo, levando as pessoas a desenvolverem atitudes distintas em relação aos produtos que lhes são ofertados.

Com o conhecimento destas diferenças a empresa pode melhor adaptar sua oferta ao mercado e, dependendo dos patamares de preços que praticar, obter uma inegável vantagem competitiva. Os consumidores procuram cada vez mais por produtos ou serviços que melhor se adaptem às suas necessidades e desejos individuais, abandonando, desta forma, o conformismo típico de um mercado de massa.

Entre as principais vantagens que a segmentação de mercados pode proporcionar, podem ser destacadas aquelas citadas por Richers; Lima (1991):

- Domínio de tecnologia capaz de produzir bens preferidos por certas classes de compradores;

- Maior proximidade ao consumidor final;

- Possibilidade de oferecer bens e serviços a preços competitivos;

- Disponibilidade de pontos de venda adequados a seus produtos ou serviços;

- Existência de veículos de publicidade que se dirijam direta e exclusivamente aos segmentos visados.

Toledo (1972) afirma que, em termos práticos, a segmentação de mercado só faz sentido se apresentar um caráter operacional. O agrupamento dos consumidores em estratos, ou segmentos, deve permitir um conhecimento maior do mercado, conduzindo a empresa a estratégias que sejam coerentes com suas metas e objetivos, considerando o ambiente em que opera. 
O processo de segmentação requer então, da empresa, uma definição clara dos grupos de consumidores para os quais ela pretenda oferecer seus produtos ou serviços.

Por outro lado, a adoção da prática de segmentação como ponto de partida para o planejamento geral traz alguns problemas que, em certos casos, podem limitar as ações da empresa. O problema principal é o custo envolvido no processo de segmentação. Alguns fatores, tais como mudanças sociais e econômicas, a evolução da tecnologia, a ação da concorrência e mesmo a legislação, contribuem para que a demanda de mercado esteja em contínua mudança. Da mesma forma, as bases para a segmentação de mercado podem mudar, a curto ou longo prazo. Esta mudança acarreta, inevitavelmente, a necessidade de atualização da base conceitual da segmentação, com vistas à tomada de decisões estratégicas, o que obriga a empresa a incorrer em custos contínuos com o processo de segmentação.

Um outro problema proveniente da segmentação é o conhecimento das forças e fraquezas da empresa com relação à concorrência. Este conhecimento é importante para a identificação dos segmentos que as empresas concorrentes têm maior probabilidade de absorver, e dos que não estão sendo alvos de sua atenção.

Desta forma, Toledo (1972) caracteriza a segmentação de mercado como sendo uma conseqüência natural da adoção do conceito de marketing voltado ao consumidor. A essência do processo de segmentação reside no conhecimento das necessidades de mercado e das vantagens que os consumidores procuram obter ao consumir um produto, conhecimento esse que representa um instrumento poderoso para a manutenção de uma base segura de operações para a empresa. Ou seja, o desenvolvimento das atividades da empresa depende da sua capacidade de atender às necessidades dos consumidores em um ambiente em constante modificação.

Segundo Simpson (2001), a decisão pela segmentação de um determinado mercado pode ser baseada na análise de alguns critérios, os quais seriam: 
- Heterogêneo: devem existir diferenças claras nas preferências do consumidor pelo produto;

- Mensurável: devem ser identificáveis e capazes de serem relacionadas a variáveis mensuráveis, como idade, sexo, estilos de vida, usos do produto etc.;

- Substancial: o segmento de mercado proposto deve ter tamanho e poder aquisitivo suficientes para ser lucrativo;

- Acionável: responder a preferências com um composto de marketing adequado;

- Acessível: o segmento de mercado proposto deve ser prontamente acessível e atingível com programas direcionados.

Existem diversos critérios para se segmentar um determinado mercado. Como dito anteriormente, a escolha das características dos consumidores que proporcionem a melhor divisão de um mercado é uma tarefa bastante difícil. É necessário, antes de tudo, que as informações sobre os consumidores existam em quantidade suficiente para orientar o processo.

O elenco de variáveis que se apresenta como critérios para segmentar mercados é muito amplo. Existem diversas maneiras para segmentar determinado mercado, principalmente se a empresa pretende combinar várias de suas formas.

Os segmentos geralmente são identificados a partir de duas correntes. Na primeira, através das características dos consumidores, independentemente do produto, utilizam-se as variáveis geográficas, demográficas e psicográficas. Na segunda, a identificação é feita por meio das respostas do consumidor diante do produto, como benefícios procurados, ocasiões de uso e lealdade à marca.

As modalidades constituídas pelas variáveis geográficas, demográficas e sócioeconômicas são usuais e mais comuns, pelo fato de terem características conciliáveis e complementares entre si, cujos dados não estão a depender de pesquisas de campo e podem ser encontrados a partir de fontes secundárias.

O mesmo não ocorre com as variáveis de segmentação por padrões de consumo, por 
benefícios procurados, por estilo de vida e por tipos de personalidades, as quais, geralmente, dependem de pesquisa de campo para se conhecer aspectos específicos das pessoas e de seus comportamentos.

\subsection{Segmentação do mercado turístico}

Além da heterogeneidade e da intangibilidade, como afirmou Beni (1988), alguns especialistas afirmam que o produto turístico não pode ser normalizado devido ao seu forte componente psicológico. Neste sentido, alguns autores falam do componente "sonho" do turismo, e da dificuldade de se padronizar sonhos.

Segundo Oliveira (2000), a importância da identificação do tipo, ou tipos, de turismo praticado em determinado local está na informação aos visitantes a respeito dos atrativos oferecidos naquela localidade, bem como na orientação aos investidores do setor.

A partir da identificação do tipo de turismo realizado em determinada localidade pode-se proporcionar à comunidade melhorias na condição de vida, através de investimentos na geração de empregos e na modernização da infraestrutura local.

Andrade (2000) pondera que os tipos de turismo existem em função da diversidade dos modos de educação, das desigualdades de níveis pessoais e grupais, do poder aquisitivo, da diversificação etária, das oportunidades e das necessidades atendidas.

O fato é que o produto turístico tem características especiais que devem ser levadas em conta quando se estabelecem as estratégias de segmentação. O uso dessas estratégias torna possível, entre outras coisas, o conhecimento dos destinos geográficos, dos tipos de transportes e, sobretudo, do perfil do turista (faixa etária, capacidade de compra, condições sociais, escolaridade, ocupação , estado civil, motivações, etc.), facilitando o atendimento às suas necessidades.

As formas de segmentar o mercado turístico foram levantadas por vários estudiosos. 
Segundo Ansarah (2002), dentre os critérios mais conhecidos, e utilizados, para a segmentação do mercado turístico, os que merecem maior destaque são os seguintes: idade, nível de renda, tipo de grupo, condições geográficas da destinação turística e motivação das viagens (onde se inclui o turismo de negócios).

Os segmentos que surgem da adoção desses critérios não são todos os existentes, havendo a possibilidade de muitos outros tipos de turismo. O que se verifica é que as empresas, ao reconhecerem um segmento, não se utilizam de apenas um critério, mas sim de uma combinação deles, formando assim segmentos híbridos nos quais pretendem concentrar suas atividades.

\subsection{O turismo de negócios}

Existe uma certa divergência entre alguns autores quando o assunto é incluir os negócios dentro da atividade turística. Para muitos deles, como Barreto (1999), quando há obrigatoriedade ou alguma finalidade lucrativa na realização da viagem, esta não poder ser considerada turística. Esses autores pregam a idéia de que o turismo envolve um ato prazeroso, onde deve haver livre escolha do destino da viagem, entendendo a atividade turística como uma forma de lazer, não admitindo, desta forma, a existência de um turismo de negócios, que estaria associado a uma ação de trabalho, geralmente ligada ao exercício de atividade remunerada.

O fato é que a realização de qualquer viagem implica na utilização das facilidades existentes no local de destino. O transporte, a hospedagem, a alimentação e o entretenimento são serviços utilizados pelo viajante e que independem do motivo da viagem e do tempo de permanência em seu destino.

Pensando desta forma, Lage; Milone (2000b) enfocam o turismo de uma maneira ampla: “...qualquer que seja o motivo da viagem, sob o enfoque econômico, mesmo que o indivíduo que viaja para um país ou região venha exercer um trabalho remunerado, ainda assim será definido como turismo". 
Nesta mesma linha encontramos a definição de Andrade (2000) para o turismo de negócios: "o conjunto de atividades de viagens, de hospedagem, de alimentação e de lazer praticado por quem viaja a negócios referentes aos diversos setores da atividade comercial ou industrial ou para conhecer mercados, estabelecer contatos, firmar convênios, treinar novas tecnologias, vender ou comprar bens e serviços." Esta definição, adotada para fins desta pesquisa, parece se aproximar mais da realidade vivida pelo mercado atualmente.

Independentemente da definição adotada para turismo de negócios, fica claro que o critério utilizado na identificação deste segmento dentro do mercado turístico é o da motivação da viagem.

Como visto anteriormente, em geral, as particularidades de cada segmento têm em comum o consumo do mesmo tipo de elemento da oferta turística. Via de regra é comum haver subdivisões dentro de segmentos de mercado. E o turismo de negócios não se apresenta como uma exceção.

Vários tipos de negócios podem ser realizados durante uma viagem. A abrangência do termo negócios sugere uma grande variedade de atividades. Elas, de uma forma geral, podem ser venda ou compra de produtos, estabelecimento de contatos comerciais, treinamento para novas tecnologias, participação em reuniões, visitas a clientes ou participação em congressos, feiras ou eventos.

Para Oliveira (2000), o turismo praticado por pessoas que estão participando de acontecimentos promovidos com o objetivo de discutir assuntos de interesses comuns (profissionais, entidades associativas, culturais, desportivas) ou para expor ou lançar novos artigos no mercado pode ser caracterizado como turismo de eventos.

O autor ainda complementa classificando os eventos da seguinte forma: congressos, convenções, seminários, mesas redondas, simpósios, painéis, conferências, fóruns, colóquios, palestras, exposições, salões, feiras, mostras, encontros, bolsas, festas, festivais e shows. 
O fato é que, apesar de existir uma diferença conceitual entre turismo de negócios e turismo de eventos, a grande maioria das instituições governamentais e privadas trata o setor de eventos como um segmento importante do turismo de negócios, incluindo neste último os dados e informações referentes ao primeiro.

Desta forma, e pelos conceitos apresentados anteriormente, esta pesquisa, no que se refere ao turismo, analisa o setor de eventos como parte integrante do turismo de negócios.

Há algum tempo o turismo de negócios vem se mostrando como uma alternativa de investimento para o setor turístico, ampliando a oferta de serviços no setor e firmando forte sinergia com o turismo de lazer. Porém, uma das principais diferenças entre o turismo de negócios e outros segmentos do setor turístico é o comportamento frente às mudanças de cenário econômico, mais precisamente em épocas de desaceleração da economia. Uma das grandes vantagens deste tipo de turismo é a manutenção de uma certa estabilidade, mesmo em tempos difíceis, garantindo um movimento consistente de turistas que resistem às crises, sobretudo pelos seguintes motivos:

1. As empresas necessitam constantemente de participar de reuniões e fechar negócios;

2. Os funcionários de empresas, empresários e profissionais liberais de todas as áreas têm necessidade de participar de feiras, congressos e outros eventos para manterem seus conhecimentos atualizados e promoverem o intercâmbio comercial, além de prospectarem novos negócios nestes encontros.

Segundo Ayres; Daemon; Fernandes (1998), a participação do setor de turismo no PIB nacional nos últimos dez anos situou-se em torno de $8 \%$ e cerca de dois terços das receitas do setor são provenientes do turismo de negócios.

Nos últimos anos, o turismo de negócios no Brasil tem apresentado crescimento como conseqüência da estabilização da economia brasileira, bem como da vinda de 
investidores e comerciantes estrangeiros. Em relação ao setor de eventos, segundo dados divulgados pelo Estudos Turísticos (2002c), o número de visitantes estrangeiros que vieram ao Brasil quintuplicou entre 1990 e 1999, passando de 40.000 para 200.000 anuais.

Segundo pesquisa realizada pelo Fórum Brasileiro Convention \& Visitors Bureaux (FBC\&VB) em conjunto com o Sebrae (Serviço Brasileiro de Apoio às Micro e Pequenas Empresas), e divulgada pelo Estudos Turísticos (2002b), sobre a importância do setor de eventos no Brasil, esse segmento representa cerca de 3,1\% do PIB nacional.

Apesar desses números, o turismo de negócios é um filão pouco explorado no Brasil, com potencial de desenvolvimento e que, eficientemente incrementado, poderá levar o país a posições melhores no setor turístico.

Dessa maneira, esse segmento, uma vez trabalhado adequadamente pelos órgãos competentes do país, pode tornar-se uma base consistente para a manutenção e o desenvolvimento do nível de atividade do turismo brasileiro.

Porém, como exposto anteriormente, o caminho a ser trilhado em busca do desenvolvimento da atividade do turismo no país só será possível se suportado por um mínimo de estabilidade econômica e política. 


\section{O SETOR HOTELEIRO}

Este capítulo apresenta o setor hoteleiro de uma forma geral, apresentando os hotéis como negócios de hospitalidade comercial, resgatando suas origens e histórico de desenvolvimento e destacando sua importância nas economias e sociedades onde operam. O objetivo é fornecer um panorama que permita mais adiante uma discussão detalhada a respeito do segmento específico dos hotéis de negócios.

\subsection{Conceitos de hotel e hospitalidade}

O produto turístico é constituído por três serviços básicos: o transporte, a hospedagem (incluindo alimentação) e o atrativo, como o lazer ou qualquer outra motivação para a viagem.

De uma forma geral, a função essencial do hotel é acomodar as pessoas que estão longe de casa e atender suas necessidades básicas.

Essa é a função básica do hotel, o que o difere de outros tipos de negócios, e à qual suas outras funções são suplementares. Em locais onde se oferece hospedagem, refeições e descanso para aqueles que estão longe de casa (como hospitais, pensionatos ou albergues) sua função essencial é outra, independentemente de visar ao tratamento, à educação ou qualquer outra coisa. Na prática, é possível traçar uma linha entre o fornecimento de acomodação por parte do hotéis e o aluguel de acomodações por meio de arrendamento, mas é mais difícil entre hotéis e pensões e estabelecimentos similares, que compartilham a função básica do hotel. Entretanto, para os fins deste estudo, é suficiente descrever o hotel como um estabelecimento que oferece hospedagem, alimentação e bebidas para os viajantes e residentes temporários e, freqüentemente, refeições e descanso, e muitas vezes outras instalações, para outros tipos de usuários. 
Segundo a Deliberação Normativa n. 367 da EMBRATUR (2002a), empresa hoteleira é a pessoa jurídica que explora ou administra meio de hospedagem e que tenha em seus objetivos sociais o exercício de atividade hoteleira.

Como meio de hospedagem entende-se o estabelecimento que satisfaça cumulativamente as seguintes condições:

I. seja licenciado pelas autoridades competentes para prestar serviços de hospedagem;

II. seja administrado ou explorado comercialmente por empresa hoteleira e que adote, no relacionamento com os hóspedes, contrato de hospedagem com as características definidas nas legislações vigentes;

III. atenda os padrões classificatórios previstos pela legislação em vigor;

IV. mantenha permanentemente os padrões de classificação.

Ainda conforme a Deliberação Normativa, os meios de hospedagem oferecerão aos hóspedes, no mínimo:

I. alojamento, para uso temporário do hóspede, em Unidades Habitacionais (UH) específicas a essa finalidade. Entende-se por Unidade Habitacional o espaço, atingível a partir das áreas principais de circulação comuns do estabelecimento, destinado à utilização pelo hóspede, para seu bem-estar, higiene e repouso;

II. serviços mínimos necessários ao hóspede, consistentes em:

a) recepção/portaria para atendimento e controle permanentes de entrada e saída;

b) guarda de bagagens e objetos de uso pessoal dos hóspedes, em local apropriado;

c) conservação, arrumação e limpeza das instalações e equipamentos.

O preço da hospedagem correspondente à utilização da UH e dos serviços incluídos, por um período básico de 24 horas, observados os horários fixados para entrada (check-in) e para saída (check-out) é definido como diária. 
Os hotéis desempenham um papel importante na maioria dos países na medida em que oferece instalações para transações de negócios, reuniões e conferências, recreação e entretenimento. Em muitas áreas, os hotéis são atrações importantes para os visitantes, contribuindo de forma significativa para a economia local, tanto direta quanto indiretamente. Além disso, os hotéis são grandes empregadores de mão-deobra, disponibilizando milhares de empregos nas mais diversas ocupações que constituem as indústrias hoteleiras.

Do ponto de vista do usuário, o hotel é uma instituição de hospitalidade comercial que oferece suas instalações e serviços para venda. Segundo Medlik; Ingram (2002), esse conceito é constituído dos seguintes elementos:

A localização coloca o hotel geograficamente em uma determinada cidade. Dentro de uma dada área a localização denota a acessibilidade e a conveniência que isso representa, a atratividade dos arredores e o apelo que isso representa, a distância do barulho e outros incômodos;

As instalações, que incluem quartos, restaurantes, bares, salas funcionais, salas de reunião e instalações de recreação, como quadra poliesportivas e piscinas, representam uma gama de instalações para uso dos clientes;

O serviço engloba a disponibilidade e a dimensão de determinados serviços do hotel fornecidos através de suas instalações; o estilo e a qualidade desses itens, em termos de formalidade e informalidade, grau de atenção pessoal, velocidade e eficiência;

A imagem pode ser definida pela forma como o hotel se auto-retrata às pessoas e pela forma como ele é percebido por tais indivíduos;

O preço expressa o valor da diária cobrada pelo hotel levando em conta sua localização, instalações, serviço e imagem, e a satisfação de seus usuários a partir desses elementos do conceito de hotel. 
O conceito de hotel pode, dessa forma, ser subdividido de acordo com as necessidades do cliente, e as instalações particulares dispostas para atendê-las. $\mathrm{O}$ conjunto de elementos do conceito de hotel é então relacionado a cada produto individual. Cada produto do hotel contém os elementos de localização, instalações, serviços, imagem e preço para atender a uma determinada necessidade ou ao conjunto de necessidades do cliente.

\subsection{Origem e expansão da hotelaria}

"O comércio é o responsável histórico pelas formas mais antigas de oferta hoteleira. As rotas comerciais da Antiguidade, na Ásia, na Europa e na África, geraram núcleos urbanos e centros de hospedagem para o atendimento aos viajantes. Na Idade Média, a hospedagem era feita em mosteiros e abadias. Nessa época, atender os viajantes era uma obrigação moral e espiritual” (Andrade; Brito; Jorge, 2002).

A importância do comércio no desenvolvimento da hotelaria é destacada desde os tempos mais antigos. Segundo Gomes (1987), as primeiras hospedarias na Europa e no Oriente Médio remontam do início do século XVII. Muitas mudanças ocorreram desde então, tanto nas formas de comércio quanto nos serviços de hotelaria.

Foi somente a partir da Revolução Industrial que a hospedagem passou a ser tratada como atividade econômica a ser explorada comercialmente. Os hotéis, no conceito que conhecemos hoje, com equipe especializada, gerentes e recepcionistas, surgiram apenas no início do século XIX.

Da mesma forma, o turismo passou a ser uma atividade econômica significativa somente após a Segunda Guerra Mundial, com a expansão da economia mundial e o aumento da renda da população, apoiado nas melhorias do sistema de transporte e comunicação. O grande aumento do número de viagens regionais e internacionais acelerou o desenvolvimento do setor turístico, que, assim, passou a ser o grande promotor das redes hoteleiras. E não foi somente a busca pelo lazer o responsável por este salto; as viagens de negócios também passaram a desempenhar importante papel 
dentro do setor turístico. Assim, com o crescimento do turismo, surgiram grandes hotéis que foram tomando lugar dos pequenos com estrutura familiar. A Tabela 3 a seguir apresenta de forma resumida os principais marcos da hotelaria no mundo.

Tabela 3 - Marcos da hotelaria no Mundo

\begin{tabular}{l|l}
\hline Antiguidade & $\begin{array}{l}\text { Estâncias hidrominerais instaladas pelos romanos na Britânia } \\
\text { (Inglaterra), na Helvécia (Suiça) e no Oriente Médio. Pontos de } \\
\text { paradas e de caravanas. }\end{array}$ \\
\hline Idade Média e Era Moderna & $\begin{array}{l}\text { Abadias e mosteiros que acolhiam hóspedes. Acomodações junto } \\
\text { aos postos de articulação dos correios. Abrigos para cruzados e } \\
\text { peregrinos. }\end{array}$ \\
\hline 1790 & $\begin{array}{l}\text { Surgimento de hotéis na Inglaterra, na Europa e nos EUA, no final do } \\
\text { século XVIII, estimulados pela Revolução Industrial. }\end{array}$ \\
\hline 1870 & $\begin{array}{l}\text { Áreas próximas às estações ferroviárias passam a concentrar os } \\
\text { hotéis no final do século XIX e nos primeiros anos do século XX. }\end{array}$ \\
\hline 1920 & Introdução do quarto com banheiro privativo (apartamento). \\
\hline 1950 & $\begin{array}{l}\text { Grande número de hotéis construídos, na década de 20, nos EUA e } \\
\text { Europa, gerado pela prosperidade econômica. }\end{array}$ \\
\hline 1970 & $\begin{array}{l}\text { Novo surto de construção de hotéis nos anos 50, coincidindo com a } \\
\text { era dos jatos e o grande incremento do movimento turístico mundial. }\end{array}$ \\
\hline Entrada em operação dos Boeing 747, em 1969/1970, com grande \\
capacidade de passageiros, impulsionando ainda mais os fluxos \\
turísticos.
\end{tabular}

Fonte: Hotel: Planejamento e Projeto. Andrade; Brito; Jorge. Editora Senac São Paulo, 2002.

\subsubsection{A hotelaria no Brasil}

A implantação de grandes hotéis nas capitais brasileiras deu-se somente a partir de 1930. Até então, existia grande escassez de meios de hospedagem no país.

A história da hotelaria brasileira inicia-se ainda no período colonial, quando os viajantes hospedavam-se nas fazendas, conventos, casarões das cidades e, principalmente, em ranchos que existiam à beira das estradas. Nessa época, era comum as famílias receberem hóspedes em suas casas, havendo, em muitas delas, o quarto de hóspedes. 
Já no século XVIII começaram a surgir os embriões daquilo que seriam os primeiros hotéis. Eram estalagens, ou casas de pasto, que ofereciam alojamento aos interessados. Inicialmente, as casas de pastos ofereciam somente refeições, porém, com o passar do tempo, os proprietários ampliaram os negócios e passaram a oferecer também quartos para dormir.

Em 1808, a chegada da corte portuguesa ao Rio de Janeiro e a conseqüente abertura dos portos trouxeram um grande fluxo de estrangeiros para o país. Com o aumento da demanda por alojamentos, nos anos seguintes os proprietários das hospedarias, tavernas e casas de pensão passaram a utilizar a denominação de hotel, com a única intenção de elevar o conceito da casa, independentemente da quantidade de quartos e do padrão dos serviços oferecidos.

Segundo Andrade; Brito; Jorge (2002), na tentativa de acabar de vez com a escassez de hotéis, sobretudo no Rio de janeiro, onde havia uma maior demanda, o governo, em 1907, criou um decreto que isentava por sete anos, de todos os emolumentos e impostos municipais, os cinco primeiros grandes hotéis que se instalassem na cidade. Foi a primeira medida governamental de incentivo à implantação de hotéis de que se tem notícia no Brasil.

A partir da década de 30, grandes hotéis foram implantados nas capitais, estâncias minerais e áreas com apelo paisagístico, os quais eram ocupados pelos interessados nos cassinos que funcionavam junto aos hotéis. Em 1946, foram proibidos os jogos de azar no país, os cassinos foram fechados e, com isso, alguns hotéis também acabaram fechando suas portas.

Em 1966 foi criada a EMBRATUR e, junto com ela, o Fundo Geral de Turismo (FUNGETUR). A partir daí, a hotelaria brasileira conheceu uma nova fase, sobretudo no segmento dos hotéis de luxo. Esse surto hoteleiro levou também a mudanças na lei de zoneamento das grandes capitais, tornando a legislação mais favorável à construção de hotéis. 
Segundo a Hotel Investment Advisors (HIA, 2002), a base da oferta da indústria hoteleira no Brasil é formada por hotéis de pequeno e médio porte, freqüentemente de propriedade familiar. A construção desses hotéis foi financiada com capital excedente dos negócios destas famílias, com a finalidade de ter um imóvel gerador de renda mas também com um forte componente emocional e de "status".

No início da década de 70, com a vinda das cadeias internacionais, a hotelaria passou a ser desenvolvida com bases mais profissionais, buscando atender as necessidades dos seus clientes potenciais. A vinda dessas cadeias hoteleiras para o Brasil coincidiu com uma fase de disponibilidade de financiamentos de longo prazo e incentivos fiscais para a construção de hotéis. Foi nesta década que foram construídos os primeiros grandes hotéis no país, sobretudo nas cidades onde havia um misto de negócios e turismo como Rio de Janeiro e Salvador.

A crise econômica no início dos anos 80 mostrava que seria difícil manter o ritmo de crescimento da oferta de novos hotéis, como ocorrera nos anos 70, em função do fim dos financiamentos de longo prazo e dos incentivos fiscais. Surge então, o fenômeno dos flats services.

\section{Flats Services ou apart-hotéis}

É necessário, para efeito deste estudo, diferenciar hotéis e flats (ou apart-hotéis).

Os flats services, como dito anteriormente, surgiram como solução para as pessoas que viajam constantemente e preferem se hospedar em um local menos impessoal do que os hotéis tradicionais. Com apartamentos com sala, quarto, cozinha e banheiro, o flat é um produto imobiliário que funciona em edifícios com prestação de alguns serviços hoteleiros. Na década de 80 , quando surgiram no Brasil, os flats eram voltados na maior parte para locações de períodos longos, porém, não raramente, eram utilizados também para moradia, face às facilidades de serviços que apresentam. 
Antes de ser introduzido no Brasil, já havia na Europa um conceito próximo ao de flat, semelhante às "residências hoteleiras" existentes na França. São espaços maiores, com cozinha e sala independente do quarto, mas não chegam a ser um hotel. Alguns não têm serviços como recepção 24 horas, restaurante e café da manhã. $O$ aluguel geralmente toma como base o apartamento, independentemente do número de ocupantes.

A partir do Plano Real, com a estabilidade econômica, a busca pela diversificação de suas aplicações levou muitos investidores ao interesse pelo mercado de flats. Esses empreendimentos passaram a ser concebidos então para funcionar exclusivamente como um hotel.

O maior exemplo de desenvolvimento de flats-services ocorreu na cidade de São Paulo, que além de ser a pioneira, foi a cidade onde este conceito mais se proliferou.

O forte mercado imobiliário da cidade, aliado à baixa oferta hoteleira, contribuíram para o grande desenvolvimento dos flats em São Paulo. A demanda hoteleira gerada por empresas localizadas em diversas regiões da cidade, encontrou assim uma opção de hospedagem que oferecia instalações novas, com bons serviços, bem localizadas e a preços acessíveis.

A implantação de um flat envolve basicamente três categorias de profissionais. Um empreendedor imobiliário, que pretende colocar no mercado todas as unidades o mais rápido possível e que tem o seu compromisso cessado após a entrega das chaves, quando se inicia a administração do prédio por uma empresa especializada; uma empresa hoteleira, que deseja operar um hotel sem investir no imóvel, e, por fim, o comprador da unidade, ou seja, o investidor imobiliário, que deseja auferir uma boa renda.

A captação dos recursos para edificação de um prédio de flats, por se dividir em pequenos módulos (cada apartamento é um módulo de investimento) torna-se muito mais fácil do que a necessária para a construção de um hotel. Com uma boa 
"bandeira", ou seja, uma operadora hoteleira de nome conhecido no mercado, tal captação se torna ainda mais fácil, atraindo assim investidores imobiliários não familiarizados com o mercado hoteleiro.

Foi justamente a ingenuidade e o desconhecimento destes investidores o fator preponderante para o lançamento no mercado hoteleiro de uma quantidade excessiva de unidades habitacionais.

Os flats se tornaram importantes para o setor de turismo ao oferecerem custos de hospedagem menores a diversos segmentos turísticos em relação às diárias praticadas nos hotéis voltados para o mesmo público.

Com relação ao público-alvo, o mercado de flats foi ampliado tendo em vista o aumento da circulação de executivos em algumas das principais cidades brasileiras atribuído à estabilidade econômica e ao desenvolvimento verificados a partir do Plano Real. Esses empreendimentos vão ao encontro da necessidade dos executivos em permanecer na cidade por períodos mais longos.

Saab; Gimenez (2001), através do Banco Nacional de Desenvolvimento Social (BNDES), publicaram um trabalho no qual apontam que as variáveis de comportamento do consumidor que implicam na escolha de hospedagem em flats são a localização e o preço, supondo uma mesma qualidade em serviços oferecidos pelos hotéis e pelos flats. Este mesmo trabalho indica que o perfil do consumidor de flats é semelhante ao do consumidor de hotel, ou seja, se os hóspedes permanecerem mais tempo na cidade, já tendo se alojado anteriormente em flats, provavelmente nestes se hospedarão. Desta maneira, os flats apresentam-se como concorrentes diretos dos hotéis.

A participação de uma operadora hoteleira é bastante importante para a comercialização dos empreendimentos. Na administração dos flats, as operadoras apresentam-se como prestadoras de serviços. Grandes redes hoteleiras passaram a prestar seus serviços na administração de flats como forma de diversificar suas 
operações. Estas redes criaram "bandeiras" que são marcas específicas dos flats sob sua responsabilidade.

Conforme exposto anteriormente, nos flats o empreendedor imobiliário assume o risco mais imediato da comercialização das unidades. Esta é uma das maiores críticas que se faz ao negócio flat. Por ocasião da incorporação de um flat, o risco do negócio é extirpado do ato de empreender. O investidor que adquire uma unidade de flat assume todo o risco da operação, embora muitas vezes não conheça o ramo de hospedagem. Esses investidores deixam seus apartamentos à disposição da operadora, mediante a garantia de receberem uma rentabilidade mínima.

Com relação à operação dos flats, faz-se necessária a busca de realização dos interesses comuns entre hóspedes e investidores, o que demonstra a importância da profissionalização da operadora e dos aspectos contratuais celebrados entre investidores e operadores. Como os demais meios de hospedagem, com o decorrer do tempo, os flats podem tornar-se defasados, sem a mesma excelência de instalações e serviços oferecidos por empreendimentos mais modernos, apresentando dessa forma taxas de ocupação menores. Os investimentos a serem realizados para a manutenção da adequação funcional também são alvos de discussão entre hóspedes e investidores, uma vez que os interesses nesse caso nem sempre são convergentes.

Quanto à concorrência com os hotéis, do ponto de vista dos empreendedores de hotéis, a diversidade de tratamento fiscal e de tarifas públicas quebra a isonomia de tratamento entre os flats e os hotéis.

Segundo a ABIH, o emaranhado legal que rege o licenciamento de edificações cria algumas situações de injustiças fiscais e de postura que contribuem para a escolha dos flats por parte dos construtores. Por força da legislação, as exigências construtivas de um apartamento residencial são muito menos restritivas quando comparadas com aquelas que regem um hotel integral. Assim, torna-se muito mais fácil edificar áreas consideravelmente menores e com exigências de segurança muito menores do que as de um hotel, ou seja, menores áreas e menores exigências levam a 
menores preços e, portanto, a maiores mercados. A questão fiscal é um outro bom exemplo desta situação. Mesmo cada município contando com a sua própria legislação, o que ocorre é que os encargos tributários acabam beneficiando os flats em relação aos hotéis. O flat, considerado edificação residencial, é menos tributado quanto a diversos impostos, tais como o Imposto Territorial Urbano (IPTU).

A Tabela 4 abaixo apresenta as principais diferenças de tratamento apontadas pelos empreendedores de hotéis.

Tabela 4 - Flats e Hotéis: Principais Diferenças

\begin{tabular}{ll}
\hline $\boldsymbol{F L A T}$ & HOTEL \\
\hline Edifício residencial & Edifício comercial \\
IPTU residencial (mais baixo) & IPTU comercial (mais elevado) \\
Sindicato dos Empregados de Edifícios & Sindicato dos Empregados de Hotéis \\
(piso salarial menor) & (piso salarial maior) \\
Tarifa de energia elétrica & residencial \\
(mais baixa) & Tarifa de energia elétrica comercial (mais \\
Tarifa de água residencial (mais baixa) & Tarifa de água comercial (mais alta) \\
\hline
\end{tabular}

Nos dias hoje, porém, mesmo com todo esse "favorecimento", a quantidade excessiva de unidades no mercado leva os atuais proprietários dos flats, iludidos pelas promessas de vendedores durante a "era dos flats", que ofereceu inicialmente resultados aceitáveis, a reconhecerem receitas muito inferiores àquelas esperadas. Em muitas localidades várias "bandeiras" de renome estão desistindo de operar empreendimentos com vocação indubitável para o fracasso. Muitas vezes, o investidor, que esperava uma certa receita, está descobrindo que adquiriu, a preço elevado, uma despesa.

Por fim, cabe registrar que em algumas cidades onde o mercado encontra-se saturado, os construtores acabam aliando-se a campanhas que objetivam impedir ou dificultar a expansão do número de unidades habitacionais de flats. 
No entanto, na cidade de São Paulo, concentrada no turismo de negócios e, por esta razão, com demanda turística mais constante do que outras capitais brasileiras, verifica-se o estabelecimento de uma intensa competição entre os flats e os hotéis.

Neste estudo, não se faz distinção entre flats e hotéis no que se refere à análise da adequação desses meios de hospedagem às necessidades do turista de negócios.

Com relação aos hotéis, na década de 90, no início do Governo Collor, o BNDES começou a oferecer uma linha de crédito especial. Assim, muitos empreendimentos hoteleiros foram financiados pelo BNDES.

Com a implantação do Plano Real em 1994, a indústria hoteleira foi ainda mais beneficiada. A estabilidade econômica do país e a sua consequiência sobre a performance dos hotéis geraram um grande interesse dos investidores institucionais, principalmente dos Fundos de Pensão, e de outros investidores atraídos pela possibilidade de retornos num patamar por eles considerado atrativo sobre o capital aplicado na construção de novos hotéis e, sobretudo, pela percepção de uma aplicação com baixo risco em prazos longos.

Além das fontes de capital internas, a indústria hoteleira atraiu recentemente a atenção do capital estrangeiro, que começou a investir em hotéis no Brasil, primeiramente através das próprias cadeias hoteleiras.

De acordo com dados da ABIH (2003), os anos entre 1996 e 2002 marcaram a indústria hoteleira brasileira como um dos períodos de maior expansão de sua oferta.

Porém, o caso dos flats-services na cidade de São Paulo mostra que a decisão do desenvolvimento de uma nova unidade hoteleira nem sempre é derivada do real crescimento da demanda hoteleira, mas sim da conjuntura do mercado imobiliário. O incorporador, na maioria das vezes, investiga se existe demanda para compra de imóveis, mas não busca certificar de que haja necessidade de uma nova unidade hoteleira dentro daquele determinado mercado. Este procedimento fez com que 
alguns mercados, como o de São Paulo, caminhassem para uma super oferta de flats, prejudicando a performance geral do segmento hoteleiro.

No cenário brasileiro atual cria-se certa expectativa quanto ao desenvolvimento do setor de infra-estrutura turística, notadamente no de hotéis de negócios.

A diminuição das oscilações na conjuntura econômica e o crescimento apresentado pelo país nos últimos anos despertaram o interesse de grandes cadeias hoteleiras internacionais, como os grupos: Accor, Choice, Hyatt, Marriott, Meliá, entre outros iniciando atividades, que estão investindo no Brasil com foco em áreas que apresentam tendências de demanda de mercado acentuadas.

\subsection{Classificação dos empreendimentos hoteleiros}

A grande variedade de hotéis pode ser observada através dos vários termos utilizados para denotar cada um dos tipos. Os hotéis são referidos como de luxo, resorts, comerciais, residenciais, de trânsito, entre muitos outros.

Cada um desses termos, apesar de servir como indicação do padrão da localidade, ou de um tipo específico de hóspede que constitui o mercado de um determinado hotel, não descreve adequadamente suas principais características uma vez que o faz segundo certos critérios.

Conforme Andrade; Brito; Jorge (2002), de uma maneira geral, os tipos de hotéis podem ser definidos:

- Conforme o padrão e as características de suas instalações, ou seja, o grau de conforto, a qualidade dos serviços e os preços. Esta é a maneira utilizada pela EMBRATUR e pela Associação Brasileira da Indústria de Hotéis (ABIH). Desta maneira, pretendem informar ao público os níveis de conforto, os preços e os serviços oferecidos; orientar os investidores e empresários; constituir instrumento de política de incentivo às atividades turísticas, etc.; 
- Conforme sua localização: hotéis de cidade, de praia, de montanha, hotéisfazenda, de aeroporto, etc.;

- Conforme sua destinação: hotéis de lazer, negócios, cassino, etc.

A grande quantidade de hotéis que existe hoje é função das diferentes solicitações do mercado, com variações às vezes muito sutis entre um tipo e outro.

Não é a intenção desta pesquisa abordar a totalidade dos tipos de hotel, mesmo porque essa tarefa provavelmente nunca estaria completa face ao dinamismo do setor que a cada ano apresenta novos tipos e subtipos. Ressalvando a necessidade de se atentar para as especificidades de cada hotel, as análises feitas aos principais tipos são aplicáveis aos que deles derivam.

Existem basicamente duas formas de classificação dos hotéis. A primeira, implantada no Brasil sob a administração da EMBRATUR, está relacionada a uma pontuação predefinida. A segunda, largamente utilizada nos Estados Unidos, é função do preço de venda das diárias.

Usualmente, no Brasil, os hotéis são classificados de acordo com os atributos de suas instalações e dos serviços oferecidos. O objetivo desta classificação é orientar os mercados turísticos internos e externos, bem como a sociedade em geral sobre os aspectos físicos e operacionais que irão distinguir as diferentes categorias de meios de hospedagem, e aos empreendedores hoteleiros sobre os padrões que deverão prever e executar em seus projetos para a obtenção do tipo e categoria desejados.

A maioria dos países adota critérios particulares para a classificação de seus estabelecimentos hoteleiros, segundo avaliação de órgãos governamentais ou de entidades especializadas no setor.

No Brasil, até 2002, existiam dois sistemas de classificação de meios de hospedagem mais conhecidos: a classificação oficial, realizada pelo Instituto Brasileiro de Turismo (EMBRATUR) e a autoclassificação, realizada por entidades privadas, e 
representada pela Associação Brasileira da Indústria Hoteleira $(\mathrm{ABIH})$. A partir de abril de 2002, estas duas instituições, através da Deliberação Normativa n. 429, publicada pela EMBRATUR, instituíram um novo sistema oficial de classificação dos meios de hospedagem.

\subsubsection{A antiga classificação da EMBRATUR}

A EMBRATUR foi criada, como empresa pública, em 1966, através do Decreto-lei n.55 na cidade do Rio de Janeiro. Somente no ano de 1991 ela foi transformada em autarquia, pela Lei n.8.181. Hoje, como autarquia especial, vinculada ao Ministério do Esporte e Turismo, a EMBRATUR tem como principal missão incrementar o turismo no Brasil, através da formulação, coordenação e execução do Plano Nacional de Turismo. Estão entre seus objetivos também a captação de recursos estrangeiros com a finalidade de contribuir para o crescimento da economia nacional, além da melhoria de vida nos municípios com potencial turístico através de um desenvolvimento sustentável.

A EMBRATUR utilizava-se de Matrizes de Classificação para enquadrar os hotéis em uma determinada categoria.

A classificação do meio de hospedagem era procedida verificando-se a compatibilidade e a conformidade entre os padrões existentes no estabelecimento e aqueles previstos nas Matrizes de Classificação aplicáveis. A Matriz de Classificação era constituída por padrões comuns e específicos aos diversos tipos e categorias de meios de hospedagem de turismo. Os itens e padrões definidos nessa matriz tinham por objetivo atender as expectativas dos hóspedes em relação aos meios de hospedagem e destinavam-se a avaliar aspectos relativos a itens gerais, de aplicação aos meios de hospedagem como um todo (posturas legais, segurança, saúde, higiene, conservação e atendimento ao hóspede), e a itens específicos, destinados a avaliar os diferentes setores do meio de hospedagem (portaria, recepção, acesso, circulação, alimentos, lazer, etc.). 
Os serviços prestados, os sistemas de gestão adotados, as instalações e equipamentos disponíveis, as áreas e aspectos construtivos existentes, quando analisados em conjunto e de acordo com os padrões de cada item (gerais e específicos) possibilitavam a aferição dos níveis de conforto oferecidos aos hóspedes. As Matrizes de Classificação (não incorporadas a esta pesquisa em virtude da extensão e detalhamento que extrapolam os propósitos deste estudo) podem ser acessadas através site da EMBRATUR (2003).

Até 2002 os meios de hospedagem podiam ser classificados em cinco categorias, representados por determinado número de estrelas, símbolo da classificação. As categorias eram as seguintes:

- Luxo Superior (

- Luxo (

- Standard Superior (

- Standard ( $*$ )

- $\operatorname{Simples}(\star)$

A validade dessa classificação sempre foi muito discutida, e em nenhum momento houve consenso quanto aos seus fundamentos. Por acharem muito rígidos alguns dos critérios impostos pela classificação da EMBRATUR, algumas entidades privadas do setor, suportadas pela Associação Brasileira da Indústria Hoteleira (ABIH), desenvolveram uma configuração que visa o estabelecimento da autoclassificação.

Entretanto, é inegável que a antiga classificação abrange os aspectos mais importantes dos projetos hoteleiros, e poderá se perpetuar como um check-list para projetos de construções, reformas e ampliações de novos empreendimentos.

\subsubsection{A antiga classificação da ABIH}

Do mesmo modo que a EMBRATUR, a ABIH também modificou o seu sistema de classificação em 2002 quando passou a fazer parte do sistema oficial de classificação 
dos meios de hospedagem. Até então, ela apresentava uma classificação representada por um processo relativamente simples, resultante do preenchimento de uma planilha pelos próprios hotéis a partir da observação dos requisitos cumpridos pelo empreendimento. Um conselho de ética era responsável pela apuração de denúncias e aplicação de multas para os hotéis que eventualmente não cumprissem os quesitos relacionados a cada categoria.

Segundo a ABIH, os empreendimentos podiam ser classificados em seis categorias, representadas por asteriscos, símbolo da classificação:

- Super Luxo (******)

- $\operatorname{Luxo}(* * * * *)$

- Superior $(* * * *)$

- Turístico $(* * *)$

- $\quad$ Econômico $(* *)$

- $\quad$ Simples (*)

\subsubsection{O Sistema Oficial de Classificação dos Meios de Hospedagem}

Como dito anteriormente, a Deliberação Normativa n. 429, de 23 de Abril de 2002, instituiu o novo sistema de classificação dos meios de hospedagem, aprovando o Regulamento Geral dos Meios e Hospedagem e o Regulamento do Sistema Oficial de Classificação dos Meios de Hospedagem, e alterando tanto o processo como a matriz de classificação dos meios de hospedagem que vigoravam até então.

Segundo a EMBRATUR (2003), o principal objetivo do novo sistema de classificação é promover o desenvolvimento da indústria hoteleira, classificando, categorizando e qualificando os meios de hospedagem no país de acordo com as condições de conforto, comodidade, serviços e atendimento que ofereçam.

A grande diferença, quando comparado aos sistemas de classificação anteriores, é a criação do Conselho Técnico Nacional, composto por representantes da 
EMBRATUR e da ABIH. Entre as atribuições do Conselho Técnico Nacional estão a coordenação e a supervisão da implantação e do funcionamento do sistema de classificação dos meios de hospedagem e a homologação dos organismos avaliadores que atendam às exigências de credenciamento do Instituto Brasileiro de Hospedagem (IBH), que é instituído e mantido pela $\mathrm{ABIH}$. Na prática, enquanto a EMBRATUR é responsável por exercer a Secretaria Executiva do Conselho Técnico Nacional, a $\mathrm{ABIH}$, através do IBH, fará o gerenciamento operacional do processo de classificação oficial dos meios de hospedagem.

Neste novo sistema oficial, as estrelas continuam sendo o símbolo da classificação, porém houve um aumento do número de categorias de 5 para 6 . As novas categorias são as seguintes:

- Super Luxo (

- Luxo (

- Superior (

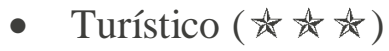

- Econômico (支苏)

- Simples (

O Sistema Oficial de Classificação dos Meios de Hospedagem, assim como os sistemas anteriores, também tem o seu processo de classificação baseado na comprovação do atendimento aos critérios da Matriz de Classificação segundo avaliação procedida por organismo credenciado pelo IBH.

\subsubsection{Outras classificações}

Do mesmo modo que existe um sistema oficial de classificação para os meios de hospedagem no país, outras classificações são adotadas pelo setor hoteleiro, a maioria delas utilizando-se das diárias médias praticadas para informar os padrões de conforto dos meios de hospedagem. 
Em alguns outros países, sobretudo nos Estados Unidos e no Canadá, o preço da diária é a única forma de classificação da categoria do hotel. O setor hoteleiro brasileiro, pela própria necessidade de sistematizar o mercado como maneira de analisar o segmento e melhor compreender os vários meios de hospedagem e suas diferentes categorias, vem nos últimos anos adotando essas classificações baseadas nos valores das diárias.

São apresentadas a seguir, em linhas gerais, algumas dessas classificações.

A classificação do Lodge Property Index (LPI)

Durante as últimas três décadas, os Estados Unidos viram a propriedade dos meios de hospedagem ser transferida de grupos familiares para grandes corporações, instituições e fundos de investimentos. Essa transformação veio acompanhada da necessidade de obtenção de informações confiáveis para aferição dos retornos sobre o capital investido.

Em 1995, um estudo realizado pela Cornell University revelou que os dados disponíveis no mercado hoteleiro não eram suficientes para a construção de uma medida adequada de retornos sobre os investimentos. Porém, a situação era diferente para os outros mercados de Real Estate nos EUA, que desde 1978 já contavam com índices trimestrais de avaliação dos retornos.

Uma vez que a falta de medidas de desempenho é um fator limitante à captação de recursos para investimentos, a American Hotel and Motel Association (AH\&MA) em parceria com a Cornell University, decidiu criar um índice trimestral de avaliação dos retornos dos meios de hospedagem.

A divulgação original do Lodge Property Index reportou os lucros e retornos de 249 meios de hospedagem durante o quarto trimestre de 1995. Essa divulgação marcou o 
início de uma série histórica do índice de retorno dos meios de hospedagem (LPI) nos Estados Unidos.

No processo de cálculo do LPI, os empreendimentos são segmentados conforme o preço das diárias médias praticadas, estabelecendo-se desta maneira três níveis de meios de hospedagem: o Upscale, que compreende o primeiro terço dos empreendimentos, ou seja, aqueles que praticam as tarifas mais elevadas, o Midprice, que corresponde ao segundo terço das tarifas e, por fim, o Economy, enquadrando os empreendimentos que praticam as tarifas mais baixas.

\section{A classificação da HVS International}

Do mesmo modo que o Lodge Property Index, a HVS International, uma empresa de consultoria hoteleira reconhecida no mercado, com o objetivo de produzir um índice setorial para medir as variações cíclicas nos valores dos hotéis, segmentou os meios de hospedagem em cinco categorias de acordo com os valores das diárias médias praticadas, acreditando que assim estaria refletindo o padrão de qualidade das instalações oferecidas. Estas diárias não apresentariam valores limites fixos, sendo ajustadas em uma escala móvel, de acordo com a localidade dos hotéis.

As cinco categorias são: Luxury, Upscale, Midscale, Economy e Budget.

\section{A classificação da Horwath International}

A Howarth International, uma das maiores e mais reconhecidas empresas de prestação de serviços para a indústria hoteleira mundial, utiliza-se de uma segmentação de mercado baseada no valor da diária média para desenvolvimento de seus estudos. Desta maneira, a empresa estabelece três categorias de meios de hospedagem, divididas da seguinte forma:

Luxury/First Class: hotéis que apresentam valores das diárias médias acima de 100 dólares; 
Superior: diárias médias entre 50 e 100 dólares;

Economy: diárias médias praticadas abaixo de 50 dólares.

As classificações baseadas nos valores das diárias médias praticadas vêm sendo amplamente utilizadas pelo mercado hoteleiro face às dificuldades de se formar um consenso, quanto aos valores das diárias a serem praticadas, relacionado à classificação formal, ou oficial, dos meios de hospedagem. Historicamente, as mais duras críticas aos sistemas de classificações oficiais apóiam-se na inadequação dos critérios de classificação, muito mais focados nas características físicas dos empreendimentos do que no nível dos serviços oferecidos, provavelmente pelas dificuldades de se medir este último.

Torna-se mais simples o processo de estabelecer os valores das diárias relacionandoas com a posição de cada produto hoteleiro na estrutura competitiva de um determinado mercado, representado por uma cidade ou mesmo região de influência.

Quando um determinado mercado de hospedagem se consolida, há uma tendência de se formar um consenso em relação aos valores que os hóspedes atribuem a cada nível de produto oferecido, valores que acabam por se equilibrar com o preço que os hotéis detectam poder cobrar pelo produto que oferecem.

Um outro fator que contribui para o uso dos sistemas de classificação baseados nas diárias é a flexibilidade. Considerando que a oferta dos meios de hospedagem em países diferentes, e até mesmo em cidades diferentes dentro de um mesmo país, apresentam diferenças significativas em termos de serviços oferecidos, estas classificações permitem uma indicação de qualidade relativa dos produtos naquele mercado. 


\subsection{A influência da economia no setor hoteleiro}

O que se pode perceber através da análise do setor hoteleiro é que o mercado de hospedagem responde com uma certa defasagem às movimentações da economia.

Segundo Gallagher; Mansour (1999), a construção de novos hotéis está ligada diretamente a dois fatores principais: a disponibilidade de capital e ao aumento das taxas de ocupação em determinadas áreas. Sempre que há maior facilidade na obtenção de financiamentos na economia os investidores do setor se vêem com recursos disponíveis e, assim, aumenta-se a oferta instalada de unidades habitacionais através da implantação de novos hotéis. O aumento da oferta é absorvido, em parte, pelo aumento da demanda até o ponto em que é caracterizado o "overbuilding", ou seja, situação na qual a oferta superou a demanda. A partir daí, com o mercado apresentando alguns sinais de saturação, os investimentos no setor diminuem até um novo momento em que a demanda supere a oferta novamente, dando início a um novo ciclo.

A defasagem que existe entre os investimentos no mercado de hospedagem e a situação econômica do país acentua um dos maiores riscos existentes nos empreendimentos imobiliários que é a possibilidade de mudança do cenário econômico. Uma vez que os empreendimentos levam de dois a três anos para serem implantados, existe um certo risco de mudança da conjuntura econômica, principalmente em países em desenvolvimento, de forma que a economia não mais se apresente favorável à operação do hotel como o era na época da concepção do empreendimento. De fato, quaisquer que sejam os fatores que levem o empreendimento a não alcançar os objetivos de inserção de mercado planejados, há uma possibilidade muito remota de se realizar a conversão do imóvel para um outro uso qualquer. Esta alta rigidez, característica comum aos empreendimentos de base imobiliária, apresenta-se como uma das mais restritivas características do investimento hoteleiro. 
Entre os indicadores macroeconômicos que mais influenciam no desempenho do setor hoteleiro, sobretudo no Brasil, destacam-se os seguintes:

- O Produto Interno Bruto (PIB), cuja variação atesta se a economia está em um ciclo de crescimento ou de crise. Diretamente ligado ao PIB está o desemprego, fator importante que sinaliza tendência dos níveis salariais e de gastos com viagens, principalmente da classe trabalhadora;

- A taxa básica de juros, que, além de influenciar diretamente nas compras a prazo pelo consumidor final, dita as regras para obtenção de financiamentos para a produção;

- A taxa de câmbio, responsável direto pelo estímulo ao turismo interno.

Um outro fator de grande preocupação dentro do cenário econômico é a concorrência internacional. As empresas, e os hotéis não constituem exceção, nos últimos anos se viram em meio a um panorama de concorrência acirrada e, na maioria das vezes, com restrições de recursos.

A concorrência tem sido fator preponderante para a mudança de estilos gerenciais, controles de custos e melhoria na qualidade dos serviços nos hotéis brasileiros e, principalmente, o trabalho de profissionais com conhecimento técnico suficiente para avaliar o mercado e propor formas de gerenciamento que diferenciem determinada organização das demais.

A preocupação com a excelência dos serviços de uma empresa, sobretudo no que se refere à hospedagem, implica na preocupação com a abordagem de aspectos intimamente relacionados ao planejamento estratégico da empresa.

Segundo Porter (1989), a organização deve conhecer as forças básicas que formam o nível global de concorrência no seu ambiente de mercado. Desta maneira, a empresa pode entender seus pontos fortes e fracos e, assim, preparar ações estratégicas. 
De acordo com Serson (2000), as principais forças competitivas que regem o ambiente dos hotéis são: os compradores, os fornecedores, os substitutos, os entrantes potenciais, os concorrentes, a tecnologia, o governo, a cultura e a economia.

Neste capítulo, os hotéis foram descritos como negócios de hospitalidade comercial cujo desenvolvimento remonta às suas origens há aproximadamente dois séculos. No próximo capítulo serão discutidos alguns aspectos específicos referentes às instalações e aos serviços do hotel como forma de amparar o estudo exploratório apresentado mais adiante. 


\section{INSTALAÇÕES E SERVIÇOS DO HOTEL}

$\mathrm{Na}$ indústria hoteleira, assim como em qualquer prestação de serviço, é fundamental que se tenha um claro entendimento do que o cliente necessita, ou seja, a agregação de valor está intimamente relacionada ao atendimento das necessidades dos clientes.

O objetivo deste capítulo é destacar as instalações e os serviços fornecidos pelos hotéis, quem são as pessoas que os utilizam e o que influencia as escolhas por determinados hotéis, no intuito de amparar o estudo exploratório apresentado no capítulo seguinte.

\subsection{A localização e o projeto do hotel}

As decisões básicas a serem tomadas na implantação de um empreendimento hoteleiro devem abordar algumas questões essenciais. Andrade; Brito; Jorge (2002) destacam duas delas:

- Para quem o hotel se destina (segmento de mercado) e qual o tipo de hotel que se pretende implantar;

- Onde localizá-lo.

Uma outra questão, levantada por Petrocchi (2002), é a seguinte: por que o cliente vai escolher esse hotel?

Desta maneira, existem várias influências do meio e da demanda que devem ser consideradas nos estudos de implantação do hotel.

A localização é uma primeira variável. E uma variável tão importante que uma localização mal resolvida pode resultar na inviabilização do empreendimento. 
O estudo de localização de um empreendimento hoteleiro pode envolver diferentes escalas no território. Para cada escala se chegará a uma resposta com precisão diferente, e para cada uma delas, será diferente o método através do qual se fará a escolha do local.

Segundo Andrade; Brito; Jorge (2002), quanto mais amplo o território que se pretende avaliar, mais genéricas serão as informações necessárias sobre o mercado. Quanto mais precisa a localização, mais aprofundadas e específicas deverão ser as informações sobre o mercado.

A escolha de um local para um empreendimento hoteleiro, em determinada cidade, vai depender de fatores que variam ou têm pesos diferentes em relação ao tipo específico de hotel que se pretende instalar. A escolha da melhor localização vai depender do tipo de hotel em estudo. Para um hotel de convenções, por exemplo, é importante que estejam localizados em cidades caracterizadas como centros de negócios e de serviços e que sejam de fácil identificação na cidade.

Medlik; Ingram (2002) afirmam que o alcance da inserção de mercado de um hotel depende fundamentalmente de sua localização em relação aos seus geradores de demanda e em relação às conveniências consideradas importantes por seus segmentos alvo. Por melhor que seja o produto, o hóspede não hesitará em migrar para outro hotel, com produto semelhante, cuja localização lhe seja mais conveniente.

O projeto do hotel é um fator decisivo na atração de clientes. Uma vez definidas a localização e a dimensão do empreendimento, o projeto passa a ser o foco das atenções no processo de desenvolvimento do negócio. O desenho arquitetônico, os arranjos físicos dos diversos setores, os padrões construtivos, a decoração de interiores e os demais aspectos do edifício onde o hotel será implantado poderão propiciar a diferenciação do empreendimento por meio do aspecto visual e facilitar o desempenho das atividades de hospedagem. 
Da mesma maneira que o desenho arquitetônico deve procurar criar diferenças relevantes e singulares, que levem o hotel a uma diferenciação no mercado, o arranjo físico pode contribuir para a agilização e racionalização dos serviços de limpeza, arrumação, manutenção dos equipamentos, fluxos de materiais de consumo, alimentos e bebidas.

Com relação ao projeto, Andrade; Brito; Jorge (2002) afirmam que o seu desenvolvimento requer o cuidadoso estudo de todas as áreas de cada setor específico do hotel, das respectivas localizações (definidas nos estudos iniciais de distribuição espacial), e a observância criteriosa das relações funcionais identificadas por meio de diagramas funcionais.

Ainda de acordo com os autores, os hotéis são constituídos pelas seguintes áreas básicas:

- Área de hospedagem - andar tipo: apartamentos e suítes;

- Áreas públicas e sociais: lobby, salas de estar, restaurantes, salão de eventos, etc.;

- Áreas administrativas: recepção, gerências, recursos humanos, etc.;

- Áreas de serviços: lavanderia, manutenção, depósitos;

- Áreas de alimentos e bebidas: recebimento, cozinha, câmaras frigoríficas, etc.;

- Área de equipamentos: subestação, casa de bombas; quadros de medição, etc.;

- Áreas recreativas: quadras de esportes, piscinas, marinas, etc.

Cada uma dessas áreas contribui de maneira significativa para o desempenho do hotel, embora variem os respectivos graus de importância, em cada caso.

A montagem do programa de um hotel inicia-se pela decisão inicial do segmento de mercado que quer se atingir, e, consequientemente, do tipo e da categoria pretendidos.

O aprofundamento do perfil do hóspede-alvo é importante para incluir no programa determinadas instalações e serviços. 
O principal fator a ser definido no dimensionamento de um empreendimento hoteleiro é o número de UH (unidades habitacionais). Tanto para a determinação do número de UH como para o dimensionamento das demais dependências do hotel, são necessárias análises particulares das características especiais de cada empreendimento. Essas análises devem levar em consideração o tipo, o porte, a localização, a categoria, o segmento do mercado a que se destina, as exigências da operadora, a legislação local e quaisquer outros aspectos que, em cada caso, apresentem relevância.

\subsection{Qualidade em serviços}

Segundo Albrecht (1995), a qualidade é uma medida de extensão até a qual uma coisa ou experiência satisfaz uma necessidade, resolve um problema ou adiciona valor para alguém.

A qualidade deve ser percebida, principalmente por quem vai usufruí-la, e necessita de comprometimento de quem vai prestá-la. Assim, a empresa que se propõe a oferecer qualidade no que faz, deve conhecer as atitudes e preferências básicas de cada cliente, ou grupo de clientes, e deve ter como foco principal as necessidades e expectativas dos clientes.

A grande diferença ao se definir qualidade na prestação de serviços encontra-se na subjetividade e na dificuldade de estabelecer o que é qualidade, uma vez que os clientes reagem diferentemente ao que parece ser o mesmo serviço. Ou seja, cada cliente possui uma determinada percepção sobre qualidade, muitas vezes esta diferença implica até mesmo em "estado de espírito do cliente" no momento da prestação de serviço. As pessoas possuem padrões diferentes de qualidade.

A avaliação dos resultados é feita simultaneamente, estando muito exposta aos clientes, e sem possibilidade de checar os resultados previamente, corrigindo falhas eventuais. 
Segundo Paladini (1995), em serviços são enfatizadas as relações diretas com os clientes e o processo deve ser flexível, porque o cliente participa do processo produtivo de forma efetiva. Portanto, as organizações precisam ser flexíveis e possuir capacidade para mudança e renovação constantes.

A qualidade dos serviços pode ser percebida pelos clientes através dos seus componentes tangíveis e intangíveis. A tangibilidade de um serviço consiste naquilo que o cliente vê, como por exemplo, a aparência física do hotel, tanto interna quanto externamente. Ou seja, conservação do prédio, jardins bem cuidados, iluminação, decoração, limpeza do ambiente, uniforme e apresentação dos funcionários. Os componentes intangíveis podem ser amabilidade, cordialidade e cooperação.

Portanto, os componentes intangíveis estão diretamente relacionados com o relacionamento do pessoal do hotel com os clientes.

\subsection{Características dos serviços de hotelaria}

A hotelaria possui algumas características que são comuns ao setor de prestação de serviços. Segundo Schemenner apud Petrocchi (2002), as mais importantes são as seguintes:

Intangibilidade: os serviços de hospedagem, embora ocorram em um conjunto de instalações físicas que influenciam no seu desempenho, possuem algo que não se pode tocar ou sentir. A hospedagem é intangível em aspectos como a ambiência da decoração, o oferecimento de um clima de hospitalidade, na assistência recebida, entre outros. Esta intangibilidade é complementada pelo fornecimento de produtos tangíveis como os móveis, lençóis, travesseiros etc. Entretanto, segundo Schemenner, quando um serviço atinge o nível de excelência, isso se deve, com certeza, à natureza intangível daquilo que está sendo fornecido e não às coisas físicas acopladas ao serviço; 
Impossibilidade de fazer estoque (perecibilidade): o consumo do serviço de hospedagem é simultâneo à sua produção. É impossível estocar. Terminada uma noite, o hotel não pode mais faturar uma diária, eliminando a possibilidade de gerar receita. Esta impossibilidade de estocar lança uma enorme importância sobre a definição do número de UHs em um hotel;

Produção e consumo fisicamente juntos: os serviços de hospedagem são criados e entregues na hora. São executados justamente onde se encontra o cliente. O esquecimento de algum detalhe, um gesto equivocado ou uma explicação mal formulada atingem o hóspede imediatamente. Há uma interação entre o hóspede e o fornecedor do serviço. O consumidor está presente no momento em que o serviço é processado;

Influências externas: a hotelaria é muito afetada por influências externas, tais como, o desempenho do sistema de turismo onde está inserida, cenários socioeconômicos, mudanças em tecnologia, regulamentações governamentais, alterações nos preços dos insumos, disponibilidade de mão-de-obra etc. Desta maneira, é necessário fazer um monitoramento constante do meio ambiente como forma de se adaptar a um processo permanente de mudanças.

O hotel reúne um conjunto de serviços tais como restaurante, copa, quarto, entre outros. Todos os fatores que fazem parte deste conjunto resultam em um serviço hoteleiro com qualidade ou não, percebido imediatamente pelo cliente.

O produto hoteleiro possui características próprias e passa obrigatoriamente pela transformação de matérias-primas envolvendo pessoas, equipamentos, e instalações, mas a sua diferença substancial está na participação indispensável do cliente no processo produtivo, pois sem este não seria possível a efetivação da prestação do serviço. 
Segundo Castelli (1994), a indústria hoteleira durante muito tempo pouco se preocupou com o real atendimento às necessidades dos hóspedes, dando mais ênfase à estrutura física dos hotéis.

Klein (1980) afirma que a estrutura de um hotel está alicerçada no tripé hospedagem, alimentação e administração. Por exemplo, um hóspede quando entra no restaurante e solicita um prato do cardápio, não está observando e sentindo a comida em si; ele provavelmente está, também, sentindo e analisando o ambiente, a limpeza da mesa, toalha, talheres. Assim, para satisfazer seu desejo de se alimentar, ficar satisfeito e ter uma sensação agradável, ainda que de modo inconsciente, ele acaba por demandar atenção de mais de uma área específica, em todo e qualquer instante que entra em contato com determinado setor.

O hotel deve apresentar uma perfeita sincronia entre o desenvolvimento das atividades de hospitalidade, administrativas e de logística de operações, para que o hóspede sinta-se satisfeito em relação a seus anseios. O hotel apresenta toda uma infra-estrutura de manutenção, como, por exemplo, departamento pessoal, almoxarifado e compras, entre outros serviços, os quais os hóspedes não percebem diretamente. Mas é essa infra-estrutura que permite que o serviço seja prestado de modo adequado à satisfação dos clientes.

Para Gianesi; Corrêa (1996), apesar de serem distintos os desejos e necessidades das pessoas, eles, muitas vezes, acabam por se assemelhar. Ou seja, cada cliente que deseja algum serviço do hotel apresenta, muitas vezes, uma particularidade em si, mas, quando se observa o conjunto de tudo o que usualmente é demandado, como, por exemplo, período de estadia, serviços de quarto ou disponibilidade de equipamentos, percebe-se grande similaridade entre os pedidos.

A prestação do serviço é a principal responsável pela percepção do cliente em relação ao serviço. 
Normman (1993) criou a expressão "momentos da verdade", para simbolizar o momento de contato entre o fornecedor do serviço e o cliente.

A percepção do cliente a respeito do serviço é formada em cada um dos momentos da verdade, ou seja, em cada momento em que o cliente entra em contato com qualquer aspecto da empresa fornecedora de serviços. Segundo Gianesi; Corrêa (1996), nem todos os momentos da verdade têm a mesma importância para o cliente, e há certos momentos da verdade críticos ou fundamentais para a percepção do cliente a respeito do serviço prestado. Esse fato, geralmente, leva o fornecedor do serviço a procurar identificar, de forma clara, esses momentos da verdade críticos, de maneira a que possa priorizar e concentrar seus esforços estratégicos, visando gerar uma percepção favorável para o cliente.

Serson (2000), a fim de caracterizar e avaliar os chamados "momentos da verdade" que ocorrem na percepção dos hóspedes, no interior de um hotel, durante o período de hospedagem, elaborou uma seqüência de momentos:

- Informações sobre localização e diárias;

- Fazer uma reserva;

- Dar entrada no hotel;

- Subir no apartamento;

- Serviço de despertador;

- Tomar café da manhã;

- Encerrar a conta;

- Efetuar o pagamento;

- Sair do hotel.

Identificar os critérios segundo os quais os clientes avaliam os serviços é uma forma de compreender melhor as expectativas dos clientes e melhor gerenciá-las.

A determinação dos critérios priorizados pelos clientes, em determinado serviço, permite que a gestão de operações de serviço estabeleça como irão funcionar, desde o 
projeto do serviço até a operação do sistema, podendo garantir o desempenho satisfatório nesses critérios priorizados. Estes critérios de avaliação devem refletir os fatores que determinam a satisfação do cliente, ou seja, a qualidade do projeto ou prestação de serviço. É necessária atenção especial para esses momentos da verdade, tendo em vista que o cliente irá comprar sua percepção dos serviços com suas expectativas iniciais, de modo a julgar sua qualidade.

\section{4 $\mathrm{O}$ atendimento ao turista de negócios}

DeRoos (1999) afirma que alguns mercados hoteleiros não se comportam como um mercado único, mas sim subdividido em segmentos que possuem necessidades específicas conforme o comportamento de sua demanda.

Baseando-se nas definições de turismo de negócios apresentadas anteriormente, o turista de negócios, para os fins deste estudo, pode então ser identificado como o homem ou a mulher que sai de sua cidade por um ou mais dias, motivado por razões profissionais, e que precisa utilizar um hotel para sua hospedagem em outra localidade. Para estas pessoas, os hotéis oferecem as instalações e os serviços de que necessitam em uma determinada área em busca de seus negócios, interesses vocacionais e outros. Nestes casos a incidência do uso do hotel surge das circunstâncias de trabalho.

Enz; Potter; Siguaw (1999) ressaltam que os hóspedes que estão em viagem de negócios apresentam necessidades específicas que devem ser atendidas da melhor forma possível pelo hotel.

Segundo os inúmeros artigos publicados por empresas de consultoria e instituições, públicas e privadas, ligadas ao setor turístico do país, o turista de negócios busca no hotel uma localização prática, que não o faça perder tempo com deslocamentos na cidade; qualidade e agilidade nos serviços que utiliza, além do respeito à sua privacidade. 
O fato é que muito pouco se conhece, no mercado brasileiro, do comportamento deste turista quanto às suas reais necessidades durante a hospedagem. Há mais especulações do que constatações. Do mesmo modo que é quase consenso que o executivo que viaja a negócios precisa, no hotel, de um "escritório longe de seu escritório", ou ao menos de uma extensão dele, e que apresentam-se como fatores decisivos para a escolha do hotel serviços de apoio como lavanderia, lojas de conveniência, barbearia etc, algumas das poucas pesquisas realizadas diretamente com estes hóspedes revelam outros tipos de necessidades.

Como exemplo, Petrocchi (2002) divulgou uma pesquisa realizada na cidade de São Paulo, no ano de 2000, pela empresa de consultoria Giorgi Consultoria para Hotéis, junto a 400 hóspedes nas categorias luxo e superluxo que viajavam a negócios para conhecer os fatores básicos que influenciam a escolha de um hotel no segmento de turismo de negócios, e os aspectos negativos que incomodam o hóspede de negócios.

Os resultados desta pesquisa estão apresentados nas duas tabelas a seguir.

Tabela 5 - A escolha do hotel : turismo de negócios em São Paulo

Fatores que favorecem a escolha de um hotel

Localização conveniente

Conforto e conservação do apartamento

Valor das diárias

Pertencente a uma rede

Serviço de business center*

Serviço de Alimento e Bebidas

Instalações de fitness center

Programas de fidelidade

Fonte: Petrocchi (2002)

* Salas para reunião/eventos, computadores, fax, secretária etc.
\% de ocorrência nas respostas

$78 \%$

$67 \%$

$65 \%$

$58 \%$

$55 \%$

$35 \%$

$30 \%$

$10 \%$ 
Tabela 6 - O que prejudica um hotel : turismo de negócios em São Paulo

\section{Fatores que incomodam o hóspede}

\section{\% de ocorrência}

Apartamento cheirando mofo

Falta de cortesia e profissionalismo do pessoal da recepção

Chuveiro com baixa pressão de água

Falta de cortesia e profissionalismo do pessoal de apoio

Café da manhã com pouca variedade

Área de trabalho pouco confortável no apartamento

Demora excessiva no check-out

Deficiências de manutenção no apartamento

Fonte: Petrocchi (2002)

nas respostas

$70 \%$
$64 \%$
$60 \%$
$60 \%$
$58 \%$
$58 \%$
$43 \%$
$42 \%$

Através dos dados acima nota-se que os serviços de business center, ou o "escritório longe do escritório" aparecem apenas na quinta posição, sendo fator decisivo na escolha de um hotel para apenas $55 \%$ dos entrevistados.

Quando a pesquisa identifica os fatores prejudiciais ao hotel, aqueles que causam má impressão aos hóspedes, as áreas de trabalho pouco confortáveis no apartamento surgem na sexta colocação, sendo fator importante para $58 \%$ dos participantes da pesquisa. Nesta questão os serviços de business center sequer foram mencionados.

Apesar da pouca divulgação, o hotel que se dispõe a atender os hóspedes que estão em viagem de negócios foi batizado pelo mercado de hotel de negócios. Assim, o hotel de negócios é o meio de hospedagem que reúne as facilidades necessárias ao abrigo de pessoas em deslocamento resultante de sua atividade econômica. Como colocado anteriormente, entre seus clientes estão incluídas, também, as pessoas que se hospedam para participar de eventos com vistas ao seu aprimoramento profissional tais como convenções, feiras e exposições, treinamentos ou congressos. 
Diferentemente dos hotéis de lazer, prioritariamente situados próximos a atrativos naturais ou socioculturais, os hotéis de negócios geralmente estão localizados nos centros urbanos e urbano-industriais, apesar de mais recentemente ser verificada uma tendência de realização de congressos e treinamentos empresariais em hotéis afastados dos grandes centros.

No próximo capítulo, será discutida a percepção dos turistas de negócios quanto aos atributos oferecidos pelos hotéis. Esta discussão será embasada, sobretudo, em uma pesquisa de campo realizada em alguns empreendimentos hoteleiros da cidade de São Paulo. 


\section{PESQUISA DE CAMPO NA CIDADE DE SÃO PAULO}

O principal objetivo deste capítulo é reconhecer a percepção do turista de negócios quanto aos atributos oferecidos pelos hotéis através da realização de uma pesquisa de campo na cidade de São Paulo. A intenção é identificar alguns dos fatores importantes quando da escolha por determinado empreendimento para sua estadia na cidade.

Será apresentada a metodologia adotada na realização da pesquisa através da identificação da cidade de São Paulo como ambiente de análise; da apresentação das premissas adotadas na definição da amostra pesquisada bem como dos critérios adotados para elaboração do questionário aplicado.

\subsection{O perfil da demanda hoteleira em São Paulo}

Baseando-se no que foi exposto no capítulo 2 a respeito da classificação dos hotéis, sobretudo no que se refere à sua destinação, pode-se, de uma maneira geral, identificar três fontes principais de geração de demanda de hotéis em uma dada área: institucional, recreacional e de trânsito.

As fontes institucionais incluem iniciativas industriais e comerciais, instituições educacionais, estabelecimentos governamentais e outras organizações do setor público e privado, cujas atividades estão envolvidas na vida econômica da comunidade e em sua administração. Tais instituições geram demanda para os hotéis através de seus próprios visitantes e de suas outras exigências por instalações e serviços do hotel.

As fontes recreacionais incluem atrações históricas, cênicas e outras atrações do local e de eventos que geram demanda para o hotel através dos turistas. 
A terceira fonte de demanda, de trânsito, provém de indivíduos e grupos sem uma razão intrínseca para passar o tempo em um determinado local, a não ser de estar a caminho de algum lugar e a necessidade de interromper a viagem.

A cidade de São Paulo, indubitavelmente, encaixa-se no primeiro tipo, as fontes institucionais.

O desenvolvimento da hotelaria em São Paulo tem os seus primeiros registros durante o século XIX. Segundo Duarte (2003), a substituição de mão-de-obra escrava pela de imigrantes na agricultura impulsionou o desenvolvimento da cafeicultura, que trouxe consigo um grande número de outros tipos de atividades comerciais e industriais. Este foi um dos fatores preponderantes para o real início da atividade hoteleira em São Paulo. As primitivas casas de hospedaria foram sendo transformadas nos primeiros legítimos hotéis, implantados na cidade no último quarto do século XIX. Porém, o grande impulso veio com a circulação dos primeiros trens da São Paulo Railway, a primeira ligação ferroviária entre Santos e São Paulo, posteriormente estendida até Jundiaí. Fica claro, desta maneira, que o surgimento da hotelaria na capital paulista esteve atrelado ao turismo de negócios.

Esta situação não sofreu grandes mudanças ao longo dos anos. O estado de São Paulo, e particularmente sua capital, desempenham um papel de grande peso na economia do país e servem como um bom exemplo para se perceber o potencial do setor hoteleiro no turismo de negócios.

Segundo dados disponibilizados em 2002 pelo Serviço Estadual de Análise de Dados (SEADE, 2002), São Paulo é responsável por 35\% do Produto Interno Bruto brasileiro e sua capital abriga a sede de 50 das 100 maiores empresas do país. É natural, portanto, que atraia grande fluxo de homens e mulheres de negócios oriundos do exterior e de todas as partes do Brasil. Essas pessoas representam uma demanda forte e crescente por boas condições para o desenvolvimento de suas atividades na capital do estado. 
Na cidade de São Paulo, o turismo primário é o de negócios. Segundo dados divulgados pela Agência de Desenvolvimento Tietê-Paraná, e divulgados pelo Estudos Turísticos (2003), referentes ao ano de 2002, este setor traz mais de 4 milhões de pessoas anualmente à cidade, movimentando 56 setores econômicos e gerando receitas que atingem aproximadamente $\mathrm{R} \$ 5$ bilhões anuais (base 2002).

Um aspecto importante na geração de demanda para os hotéis é a grande quantidade de feiras, congressos e eventos realizados na cidade. Ainda segundo a ADTP, das pouco mais de 170 feiras anuais de grande porte realizadas no Brasil, perto de 140 são feitas em São Paulo.

De um modo geral, os locais que abrigam as grandes eventos anuais que ocorrem na cidade de São Paulo estão distribuídos conforme mostra a Figura 1.

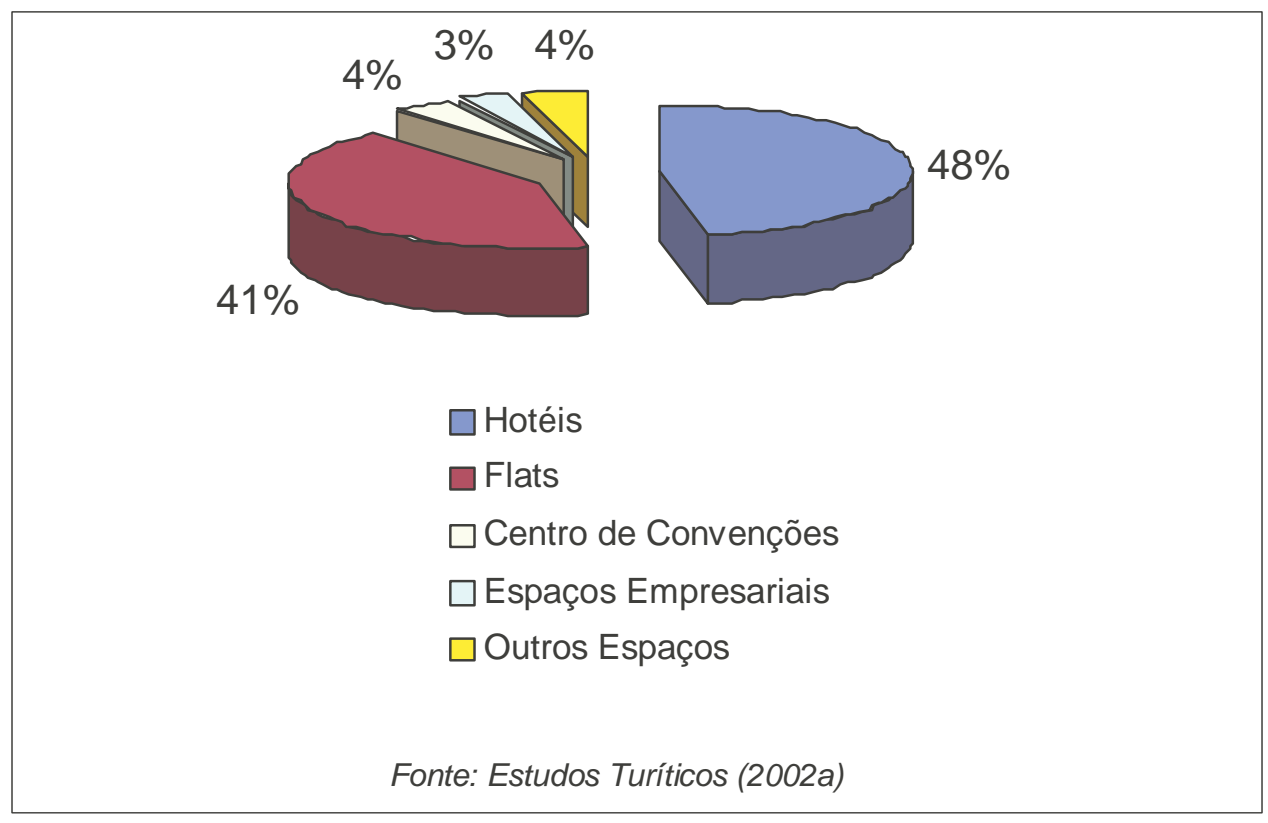

Fig. 1 - Locais dos eventos em São Paulo

Através da análise dos dados acima, constata-se que a grande maioria dos eventos, quase 90\%, acontece em instalações hoteleiras. Essa é uma das razões da franca expansão apresentada pelo mercado hoteleiro da cidade de São Paulo nos últimos anos. 


\subsection{Metodologia da pesquisa de campo}

\subsubsection{Justificativa metodológica}

Muitos pesquisadores admitem a separação dos métodos qualitativo e quantitativo de análise de dados. Porém, atualmente, entende-se que essas formas de pesquisas estão interligadas. Um estudo qualitativo serve para encontrar novas respostas a um problema, enquanto que um estudo quantitativo serve para expressar relações estatísticas entre os resultados obtidos.

Desta maneira, os dois tipos de análises são atualmente trabalhados de forma complementar. A análise qualitativa possibilita a elaboração de categorias, hipóteses e idéias, enquanto que o processo quantitativo possibilita confirmação dessas hipóteses mediante a aplicação de testes apropriados observando-se o grau de significância das relações entre as variáveis pesquisadas.

Segundo Alves (1991), atualmente há uma grande variedade de pesquisas que recebem a denominação de qualitativas: naturalistas, pós-positivistas, antropológicas, etnográficas, estudos de caso, hermenêuticas, fenomenológicas, ecológicas, construtivistas. Talvez a utilização do termo "qualitativa" não seja um qualificativo adequado para designar tais modalidades de pesquisa visto que as pesquisas ditas "quantitativas" também analisam qualidades dos seus objetos de estudo.

De fato, o que se pretende nesta pesquisa é construir um conhecimento que se apoie na dimensão qualitativa das variáveis estudadas, perspectivando porém uma abordagem quantitativa que permita algum tratamento estatístico julgado pertinente. Objetiva-se, deste modo, realçar que a metodologia qualitativa se apresenta realmente como a mais pertinente, apesar da técnica que se pretende utilizar no desenvolvimento da pesquisa: o questionário.

A análise qualitativa tem um caráter especulativo. Trata-se de uma primeira abordagem, na qual pode-se desenvolver a primeira série de categorias, que 
posteriormente servirão para a formulação de hipóteses e testes estatísticos, paramétricos ou não paramétricos. A análise qualitativa de dados insere-se dentro de uma abordagem metodológica que possibilita a criação de categorias de respostas e de modelos teóricos dos fenômenos analisados.

Chizzotti (1991) afirma que no processo de análise qualitativa, o pesquisador mobiliza sobretudo sua acuidade inventiva e perspicácia para elaborar a metodologia da pesquisa, o que não quer dizer que outros métodos, inclusive quantitativos, não possam ser usados.

Ainda segundo Alves (1991), o pesquisador pode e deve elaborar um projeto para avaliar a viabilidade e a relevância do estudo, destacando que os delineamentos podem ter níveis maiores ou menores de estruturação.

Aqueles que defendem uma estruturação maior, como no caso desta pesquisa, argumentam que o pesquisador sempre possui uma teoria orientando seus procedimentos e que, ao escolher uma situação a investigar, já possui alguns pressupostos a respeito dela, devendo estar explícitos ao início da pesquisa. Os defensores da pré-estruturação alertam para o aspecto de que a ausência de focalização e de critérios na coleta de dados resulta em perda de tempo, excesso de dados e dificuldade de interpretação, dificuldades estas agravadas quanto menor for a experiência do pesquisador.

Esta é, portanto, uma justificativa da atitude metodológica aqui adotada.

\subsubsection{Seleção da amostra}

A definição de critérios segundos os quais é selecionada a amostra que compõe o universo da investigação é uma etapa importante no processo de pesquisa de campo pois interfere diretamente na qualidade das informações a partir das quais será possível construir a análise e chegar à compreensão mais ampla do problema delineado. 
A amostra para esta pesquisa foi constituída a partir do universo das pessoas que estavam em viagem de negócios na cidade de São Paulo, hospedadas nos hotéis da cidade.

Para a seleção da amostra buscou-se diversificar os hotéis onde seriam aplicados os questionários aos hóspedes quanto à diferença de porte e localização. Inicialmente, foram identificados empreendimentos de diferentes redes e níveis de qualidade.

Quanto à localização, buscou-se mapear na cidade de São Paulo algumas regiões que apresentassem, simultaneamente, grande concentração de hotéis e de escritórios comerciais, fontes geradoras de demanda para os hotéis.

O resultado deste estudo apresentou as seguintes regiões potenciais para a aplicação da pesquisa na cidade.

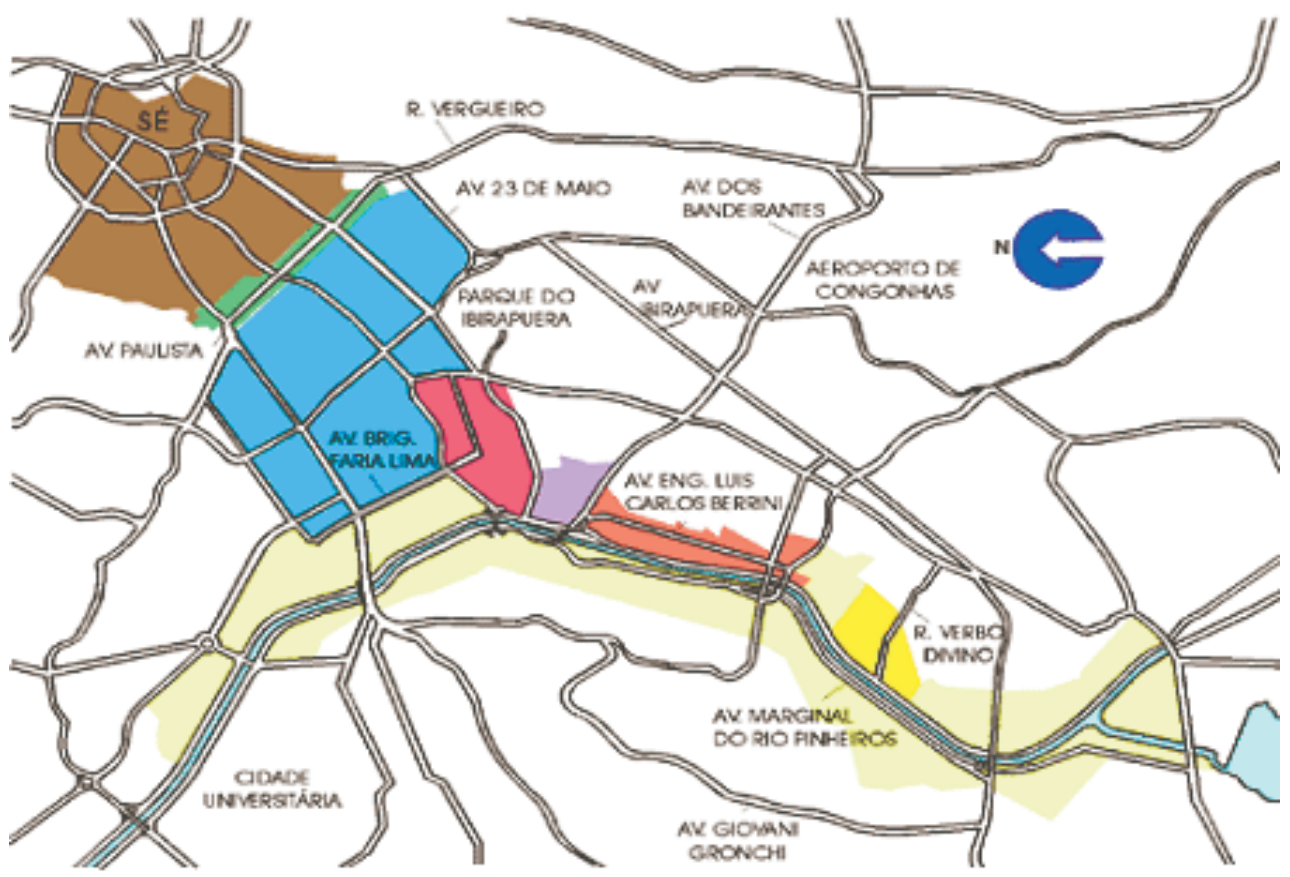

Fonte : Bolsa de Imóveis do Estado de São Paulo

Fig. 2 - Regiões de concentração de hotéis e escritórios em São Paulo 
Região Central, com os seguintes limites: ao Norte, avenidas São João e Duque de Caxias e Rua Mauá; a Leste, Parque Dom Pedro e Rua do Glicério; ao Sul, Viaduto do Glicério, Avenida Liberdade e ruas Vergueiro e do Paraíso; e a Oeste, ruas Cincinato Braga, São Carlos do Pinhal, Antônio Carlos, Bahia e Albuquerque Lins.

Avenida Paulista, com os seguintes limites e confrontações: tem como eixo a Avenida Paulista e compreende a área cujo perímetro é definido pelas seguintes vias: a Oeste, ruas da Consolação e Minas Gerais; fazendo limite com a região Centro, Avenida Angélica e ruas Maceió, Matias Aires, Antônio Carlos, São Carlos do Pinhal e Cincinato Braga; ao Sul, Avenida 23 de Maio e ruas do Paraíso e Abílio Soares; e confrontando com a região Jardins, Rua Cubatão e Alameda Santos.

Jardins, confronta com a região Paulista na Alameda Santos e Rua Cubatão; ao Sul, seus limites são a Avenida 23 de Maio, o Parque do Ibirapuera e a Avenida Brigadeiro Luís Antônio; confronta com a região Itaim nas avenidas São Gabriel e Nove de Julho e com a região Faria Lima nas avenidas Cidade Jardim e Brigadeiro Faria Lima; e a Oeste, seus limites são as ruas Baltazar Carrasco e Cardeal Arco Verde e Avenida Dr. Arnaldo.

Avenida Brigadeiro Faria Lima, região que compreende a Avenida Brigadeiro Faria Lima (antiga e nova) e parte da Avenida Cidade Jardim. Suas confrontações são as regiões Jardins, Itaim e Marginal.

Itaim, com os seguintes limites e confrontações: ao Norte, faz divisa com as regiões Marginal, Faria Lima e Jardins; ao Sul, seus limites são a Avenida Santo Amaro, Rua Dr. Eduardo de Souza Aranha e Avenida Presidente Juscelino Kubitschek; e a Oeste confronta com a região Vila Olímpia e com a Avenida das Nações Unidas (Marginal do Rio Pinheiros).

Vila Olímpia, com os limites: ao Norte, confronta com a região Itaim; a Leste, ruas Ramos Batista, Olimpíadas e Alvorada; ao Sul, Avenida dos Bandeirantes; e a Oeste, Avenida das Nações Unidas (Marginal do Rio Pinheiros). 
Avenida Luiz Carlos Berrini, que tem como eixo a própria avenida.

A partir da identificação das áreas potenciais para a pesquisa, foi iniciada a seleção dos empreendimentos inseridos naquelas localidades.

O primeiro passo desta seleção foi a identificação de hotéis que cobrassem uma diária mínima de $\mathrm{R} \$ 100,00$ (cem reais - base out/2003). Este foi um valor arbitrado com a intenção de selecionar o público-alvo. O objetivo deste critério foi excluir da amostra os chamados hotéis econômicos, onde os hóspedes usualmente não exigem mais do que o necessário para uma noite de repouso. Por este motivo, caracterizamse por não se preocuparem em oferecer muito mais do que um atendimento adequado na recepção, troca das roupas de cama e banho, limpeza e manutenção das dependências do hotel, preparo do café da manhã e o funcionamento de eventual lanchonete. Desta maneira, não são empreendimento que se enquadram nos propósitos deste estudo.

Assim, a seleção inicial dos hotéis levantou 41 empreendimentos como possíveis alvos da pesquisa.

O segundo passo consistiu no contato com os empreendimentos para apresentação dos objetivos da pesquisa e solicitação para colaboração na mesma. Na maior parte dos casos este primeiro contato foi feito pessoalmente, através de visitas ao empreendimento. Em alguns casos o contato foi feito via telefone. No intuito de facilitar a aproximação foi elaborada uma carta de apresentação, dirigida ao gerente do hotel e entregue em mãos nas ocasiões das visitas aos hotéis.

Após o primeiro contato, 20 empreendimentos recusaram-se a participar da pesquisa.

O principal argumento da recusa foi que a solicitação aos hóspedes de preenchimento de questionários não fazia parte da política da empresa. Desta maneira, restaram 21 empreendimentos que estariam analisando a solicitação de colaboração na pesquisa. 
Deste saldo de 21 hotéis, 12 aceitaram receber os questionários e solicitar aos hóspedes o preenchimento dos mesmos. Neste caso, o principal argumento para a recusa foi a alegação de que, por já possuírem questionários próprios com questões semelhantes ao da pesquisa, estariam sobrecarregando os hóspedes, causando possíveis constrangimentos.

A relação final dos empreendimentos que aceitaram colaborar com a pesquisa está apresentada na tabela a seguir.

Tabela 7 - Relação dos hotéis participantes da pesquisa

\section{Empreendimento}

Clarion Berrini

Estanplaza Berrini

Estanplaza Funchal

Estanplaza Nações Unidas

Feller Saint Denis Suite

Linson Suite Hotel

Meliá Confort Itaim

Meliá Confort Jardins

Meliá Jardim Europa

Quality Jardins

Quality Suítes Imperial Hall

Tryp Pamplona

Foram distribuídos, no total, 170 (cento e setenta) questionários entre os hotéis apresentados na lista acima. O número de questionários distribuído a cada empreendimento não foi o mesmo, sendo que alguns hotéis receberam 10 questionários, a maioria recebeu 15 e o restante dos hotéis aceitaram receber 20 questionários.

A orientação transmitida aos hotéis, na maioria das vezes ao gerente operacional, foi que os questionários deveriam ser entregues aos recepcionistas, e que estes fossem 
orientados a entregá-los somente aos hóspedes que se encontravam em viagem de negócios.

Considerando as dificuldades encontradas no processo de aproximação aos hotéis (recusa na participação da pesquisa) e os problemas encontrados pelos hotéis no convencimento dos hóspedes ao preenchimento do questionário, e visando a obtenção de uma amostra que proporcionasse uma análise adequada das respostas, optou-se por aplicar o questionário não somente nos hotéis, mas também diretamente aos viajantes que encontravam-se em São Paulo e que não estivessem necessariamente no hotel no momento da resposta à pesquisa.

Para facilitar o contato com os representantes desta nova amostra, o questionário inicial foi adaptado de modo a representar esta nova situação (a resposta ao questionário em local diferente do hotel) e elaborado em arquivo digital (utilizandose planilha do Microsoft Excel). A intenção foi, além de aumentar o tamanho da amostra, agilizar o envio, preenchimento e recebimento dos questionários utilizandose da comunicação via e-mail. A distribuição deste questionário digital, que apresenta a mesma estrutura do primeiro, foi feita pontualmente a pessoas que encaixavam-se no perfil da pesquisa. O e-mail com o questionário era encaminhado com a devida explicação a respeito de seu preenchimento. Como forma de controle deste processo, diferentemente do anterior, neste questionário digital foi requerida a identificação do hotel que o respondente estava, ou esteve hospedado nos últimos dias.

A amostra obtida através deste caminho de distribuição foi de 32 hóspedes. A relação dos hotéis onde encontravam-se hospedados está apresentada na tabela a seguir. 
Tabela 8 - Relação dos hotéis avaliados na pesquisa via $e$-mail

\begin{tabular}{l}
\hline Empreendimento \\
\hline Blue Tree Faria Lima \\
Feller Saint Denis Suite \\
Intercontinental Hotel \\
Meliá Confort Itaim \\
Meliá Iguatemi \\
Quality Jardins \\
Paulista Plaza \\
Renaissance
\end{tabular}

\subsubsection{Construção do instrumento de pesquisa}

Segundo Gunther (1999), o comportamento humano, no contexto das ciências sociais empíricas, pode ser compreendido através de três maneiras:

i) observar o que ocorre naturalmente no ambiente real;

ii) criar situações artificiais e observar o conseqüente comportamento;

iii) perguntar às pessoas sobre como (por que, quando, etc.) fazem o que fazem.

Cada uma dessas técnicas - conhecidas, respectivamente, como observação, experimento e survey (ou levantamento) - apresenta vantagens e desvantagens em relação à qualidade e potencial de utilização dos dados obtidos.

Ainda segundo o autor, o levantamento de dados por amostragem, ou survey, ou simplesmente levantamento, assegura melhor representatividade e permite generalização para uma população mais ampla. "A técnica consiste na apresentação de um questionário estruturado, ou seja, uma série de perguntas escritas ou verbais, a uma amostra de uma população, visando obter informações específicas dos entrevistados" (Malhotra, 2001). Tal questionário pode ser aplicado através de 
interação pessoal (em forma de entrevista individual ou por telefone) ou ser autoaplicado (recebido pelo correio ou ser colocado à disposição).

De qualquer forma, o desenvolvimento de qualquer questionário deve seguir um processo lógico, conforme ilustrado na Figura 3.

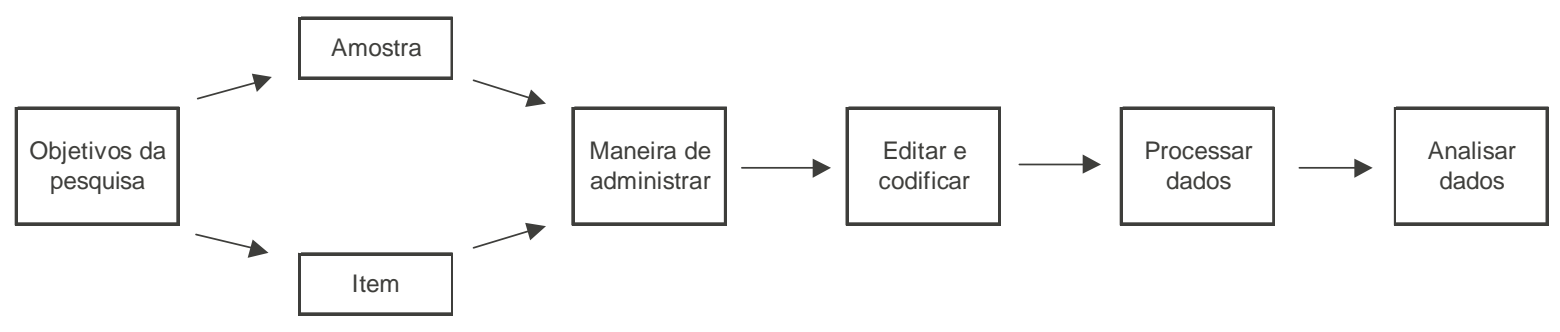

Fonte: Schuman; Kalton (1985) apud Gunther (1999)

Fig. 3 - Estágios principais de um Levantamento

A figura anterior mostra como a definição dos objetivos da pesquisa leva necessariamente à relação item e amostra. No processo de pesquisa, cada um dos elementos do binômio deve ser tratados paralelamente.

Malhotra (2001) afirma que o processo de desenvolvimento de um questionário deve seguir o seguinte roteiro:

1. Especificar a informação necessária;

2. Especificar o tipo de método de abordagem do respondente;

3. Determinar o conteúdo das questões;

4. Definir uma questão para superar a inabilidade ou indisposição do respondente (filtro);

5. Decidir sobre a estrutura das questões;

6. Definir a redação final das questões;

7. Determinar a ordem das questões;

8. Definir o formato do questionário;

9. Reproduzir o questionário; 
10. Eliminar possíveis erros através de pré-testes.

Segundo o autor, a fim de superar o desinteresse do respondente de participar da pesquisa, o pesquisador deve tomar algumas medidas:

1. Minimizar o esforço e custo dos respondentes;

2. Perguntar somente as questões relacionadas ao objetivo determinado;

3. Explicar ao respondente o porquê da necessidade da informação;

4. Eliminar a possibilidade de o respondente ficar embaraçado.

Além disso, a estrutura e sequiência das perguntas são também fatores importantes, devendo-se ir do mais geral para o mais específico.

Para se garantir respostas fidedignas e válidas, devem ainda ser seguidos alguns critérios nos itens a serem empregados no questionário:

1. As perguntas precisam ser compreendidas consistentemente;

2. As perguntas precisam ser comunicadas consistentemente;

3. As expectativas quanto a respostas adequadas precisam ser claras para o respondente;

4. Os respondentes devem ter toda informação necessária (exceto se as perguntas estiverem verificando conhecimento) para produzir respostas válidas;

5. Os respondentes precisam estar dispostos a responder.

"Para assegurar tais atributos, cada pergunta deve ser específica, breve, clara, além de ser escrita com vocabulário apropriado e correto" (Gunther, 1999).

O questionário aplicado aos hóspedes foi elaborado visando obter informações que permitissem identificar suas percepções referentes aos atributos oferecidos pelo hotel, atributos estes que justificam a preferência por um dado empreendimento para sua estadia na cidade de São Paulo. 
Os próximos parágrafos apresentam em linhas gerais as principais diretrizes que nortearam a elaboração do questionário. O objetivo detalhado de cada uma das questões, bem como a relação entre elas para efeito da análise dos dados estão apresentados no próximo capítulo, onde se apresenta e discute os resultados obtidos na pesquisa de campo.

Inicialmente, buscou-se identificar os fatores que levam o hóspede à escolha do hotel e a importância destes fatores em uma viagem cujo propósito seja a realização de negócios. Um dos principais objetivos do questionário, traduzidos nas questões 3 e 4 , foi verificar se as expectativas do hóspede são de fato diferentes quando este encontra-se em viagem de negócios.

Em um segundo momento, a intenção era identificar aspectos particulares dentre os fatores de escolha que o hóspede considera importantes. Foi dado especial destaque para dois fatores: a localização do hotel e os equipamentos/serviços oferecidos.

Buscou-se, desta maneira, entender o comportamento do hóspede com relação à importância da localização do hotel como, por exemplo, a preferência por um hotel de fácil acesso a partir do aeroporto ou por um hotel próximo a opções variadas de lazer. Quanto aos equipamentos/serviços oferecidos pelo hotel a idéia principal foi identificar qual a parcela dos turistas que estão a negócios realmente valorizam uma infra-estrutura voltada ao desenvolvimento de seu trabalho no próprio hotel. Em resumo, a intenção foi, após a constatação das diferentes percepções dos hóspedes que estão a negócios, identificar os fatores de maior peso na satisfação deste hóspede.

A partir de então o questionário dirigiu-se à fidelidade do cliente a um mesmo hotel, à avaliação das opções apresentadas pela cidade de São Paulo e, por fim, à satisfação do hóspede com o hotel sobre o qual respondeu ao questionário.

$\mathrm{Na}$ última questão, na qual já se esperava índice de resposta inferior às demais devido ao seu caráter descritivo, solicitava-se ao hóspede apontar o que ele considera 
o maior problema da hospedagem da cidade de São Paulo quando o assunto é viagem de negócios.

O modelo do questionário aplicado diretamente nos hotéis encontra-se no ANEXO 1 desta pesquisa.

O modelo do questionário encaminhado via e-mail encontra-se no ANEXO 2 desta pesquisa.

O processo de elaboração do questionário procurou seguir, passo a passo, o roteiro proposto por Malhotra (2001), apresentado anteriormente neste capítulo. Porém, houve dificuldade na adoção de algumas medidas sugeridas pelo autor para superar o desinteresse do respondente. Entre elas estão:

- Explicar ao respondente o porquê da necessidade da informação;

- Eliminar a possibilidade de o respondente ficar embaraçado;

- A garantia da disposição em responder às questões.

A dificuldade em se adotar estas medidas está no fato do responsável pela distribuição dos questionários e solicitação das respostas ser o funcionário da recepção do hotel, sem acompanhamento do pesquisador. Esta dificuldade constituise em um fator de risco no processo, que é a forma de abordagem ao hóspede pelo funcionário do hotel. Para minimizar este risco foi dada atenção especial às orientações de preenchimento quando da entrega dos questionários ao gerente operacional do hotel. 


\section{ANÁLISE DOS RESULTADOS DA PESQUISA}

Os dados para reflexão aqui apresentados foram extraídos das questões de números 1 a 13, integrantes do questionário e com objetivos exploratórios, sendo passíveis de algumas limitações, dadas as circunstâncias de elaboração do questionário.

Durante o processo de análise qualitativa, é importante definir instrumentos metodológicos que permitam captar de forma aberta aspectos dos fenômenos que se está analisando. Isso para que se possa captar alguns aspectos inesperados e até mesmo impensados do fenômeno. As conclusões de uma análise qualitativa apenas indicam tendências gerais e ajudam a formular hipóteses. No final de uma análise desse gênero, está-se apto a emitir conclusões que podem até afirmar que 'parece existir uma relação do tipo A entre as variáveis x e y'. Ou seja, as conclusões são específicas, claras mas não podem ser assertivas.

\subsection{Generalizações e validação dos dados}

Um outro aspecto importante da pesquisa de campo é a representatividade do dado. O critério para busca de dados representativos reside na condição de serem selecionados pessoas e contextos onde a experiência do fenômeno a ser estudado esteja ocorrendo.

Tal critério para seleção das fontes de dados implica, diretamente, na forma como ocorrerá a generalização dos conhecimentos obtidos. Distintamente de uma generalização formal, normalmente oferecida como resultado de pesquisas quantitativas pautadas pelo rigor estatístico, fala-se de uma "generalização naturalista" (Stake, 1983). A generalização naturalista é aquela deduzida pelo leitor ou usuário da pesquisa a partir dos elementos e informações fornecidas pela mesma. Origina-se a partir de como a experiência vivida do pesquisado esteja configurada. 
Ainda segundo Stake (1983), o que o pesquisador qualitativo deve fazer para que os leitores elaborem suas generalizações é apresentar:

a) relatos ou descrições suficientes dos fenômenos estudados, discursos, entrevistas realizadas;

b) interpretações próprias e de outros pesquisadores sobre o assunto; c) os processos pelos quais os dados foram coletados, analisados, sintetizados e interpretados, bem como os procedimentos de validação empregados.

Além do critério da transferibilidade, ou generalização, conforme apresentado acima, que analisa a possibilidade de estender as conclusões a outros contextos, os resultados de análises qualitativas precisam ser validados por outros critérios. Pelo critério da fiabilidade o pesquisador confronta suas interpretações com as das pessoas pesquisadas ou com as de outros pesquisadores como forma de controle da própria ideologia, e pelo critério da credibilidade (Alves, 1991; Chizzotti, 1991), dá-se crédito ao pesquisador através da busca da garantia de que o estudo tem alto grau de exatidão, avaliando a qualidade e a quantidade das observações efetuadas e das informações colhidas.

\subsection{Apresentação e discussão dos resultados}

Durante 88 dias - 20/10/03 a 16/01/04 - foi acompanhada a aplicação dos questionários a fim de monitorar o processo de coleta dos dados, bem como recolher os questionários já preenchidos.

No total, entre a distribuição nos hotéis e os envios através de e-mail, foram entregues 202 questionários, dos quais 79 (39\%) retornaram preenchidos.

Esta taxa de preenchimento dos questionários deve-se, segundo relato dos funcionários dos hotéis, à falta de disponibilidade, tempo, interesse e esquecimento por parte dos hóspedes. Os questionários enviados via e-mail apresentaram um taxa 
de preenchimento muito superior. Foram devolvidos preenchidos 23 questionários, aproximadamente $72 \%$ dos 32 questionários enviados.

Para facilitar a visualização dos resultados foi utilizado software de planilhas eletrônicas (Microsoft Excel), o que possibilitou a produção de tabelas e gráficos, os quais são apresentados a seguir.

\section{Questão 1}

\section{Quantas vezes esteve na cidade de São Paulo anteriormente?}

Esta questão apresentou 3 alternativas de respostas: primeira vez, até 5 vezes ou mais de 5 vezes, e tinha dois objetivos. O primeiro deles foi a realização de um filtro. Em conjunto com a questão 9, foi elaborado um teste à atenção do respondente ao questionário. Dos 79 questionários respondidos, apenas 2 não passaram neste filtro, apresentando respostas incompatíveis. As respostas foram consideradas incompatíveis quando apresentaram "a primeira vez" como resposta da questão 1 e "sim" na resposta da questão 9, indicando que apesar de ser a primeira vez na cidade, o respondente tinha como hábito utilizar-se de opções diferentes de hospedagem. Os questionários com respostas incompatíveis foram eliminados do processo de análise dos dados recolhidos na pesquisa.

O segundo objetivo da questão 1 foi levantar um perfil dos hóspedes quanto ao conhecimento da cidade. A intenção foi perceber com que experiência o hóspede respondeu a respeito dos fatores presentes nas questões da pesquisa tais como localização, opções de lazer, valor das diárias dos hotéis e opções de hospedagem na cidade. Os resultados podem ser visualizados na Figura 4.

Como se percebe, cerca de $82 \%$ dos respondentes já tinham estado na cidade de São Paulo anteriormente. 


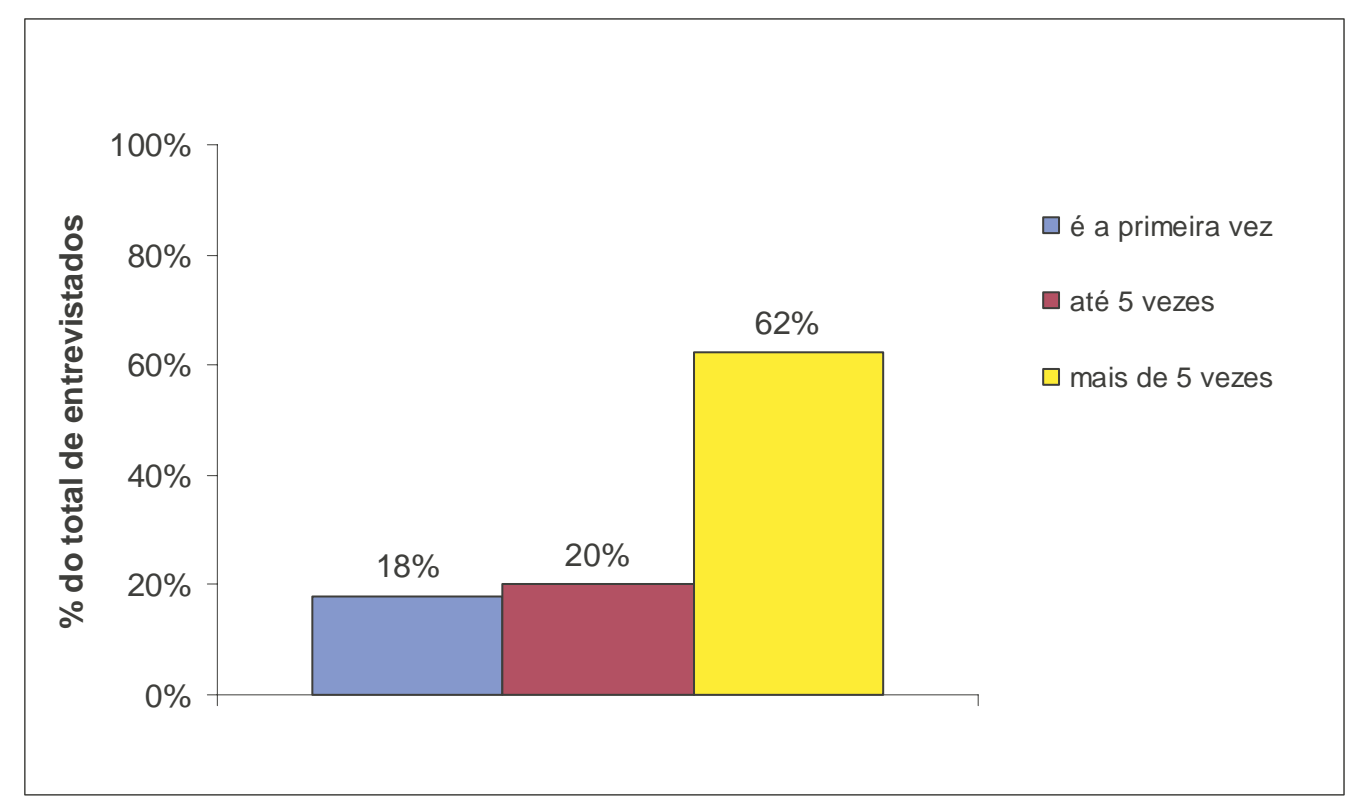

Fig. 4 - Quantas vezes esteve em São Paulo anteriormente

\section{Questão 2}

\section{Quanto tempo permaneceu ou pretende permanecer na cidade?}

A média de permanência na cidade entre os respondentes, como indica a Figura 5, está acima dos 3 dias. No entanto, a análise fica mais adequada se separarmos os números em percentis. Pode-se observar que há grande proximidade deste resultado com pesquisas realizadas por outros órgãos do setor turístico. Segundo pesquisa realizada pelo São Paulo Convention \& Visitors Bureaux (SPCVB), e divulgada pela ADTP (2004), a média de permanência do turista de negócios na cidade de São Paulo, participantes de eventos na cidade, está em 3 dias. Por falta de dados disponíveis para o turista de negócios em geral, não somente os participantes de eventos, foi tomado o dado acima como referência. 


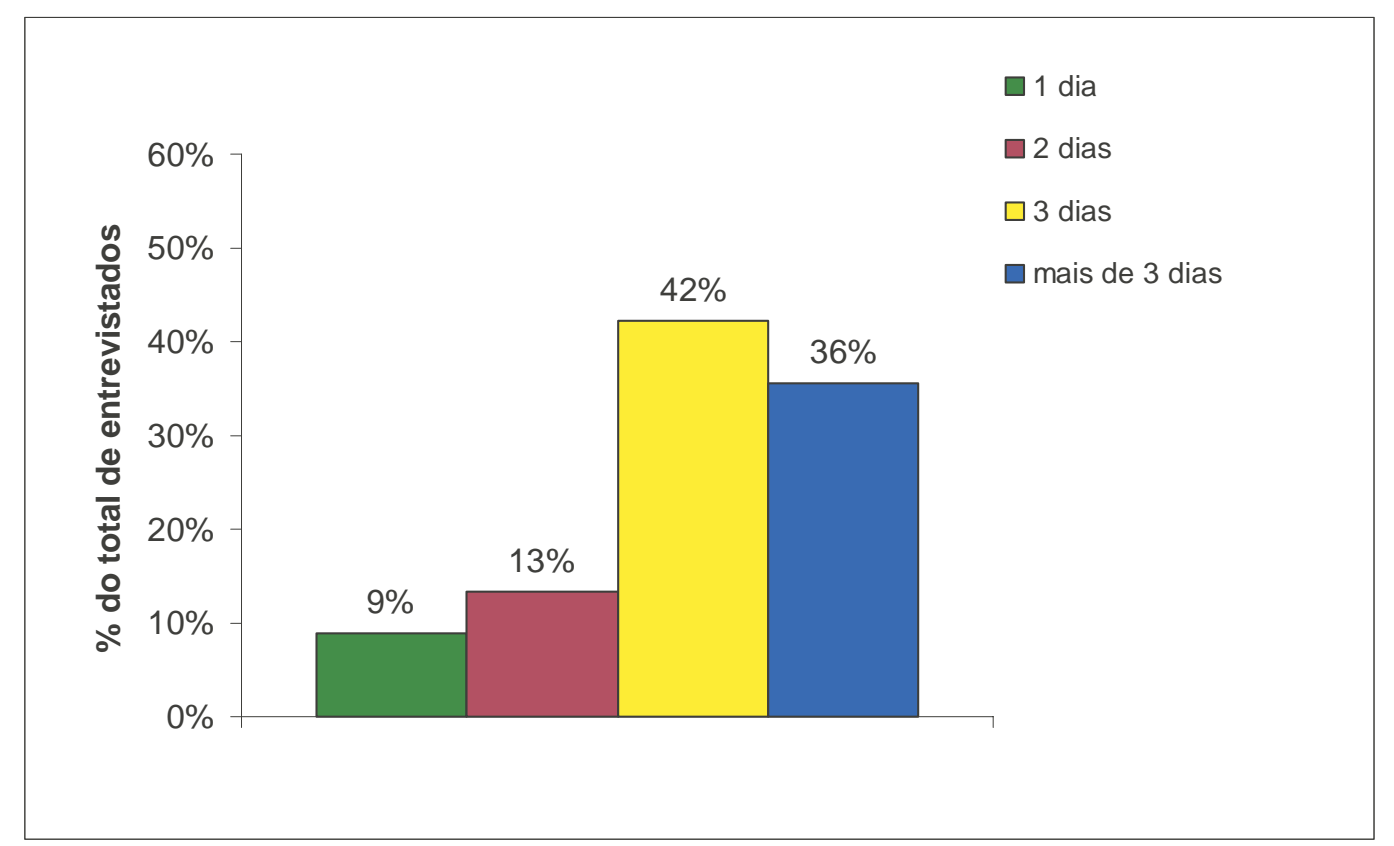

Fig. 5 - Quanto tempo permaneceu ou permanecerá na cidade

\section{Questão 3}

Por favor, ordene (de 1 a 4), conforme a importância, os fatores que considera decisivos para a escolha do hotel no qual irá se hospedar.

Nesta questão, os respondentes deveriam ordenar, conforme a importância , em uma escala de 1 a 4, os fatores decisivos na escolha do hotel. 
Em um primeiro momento, foi analisado o número de ocorrências dos graus de importância (1 a 4) para cada fator decisivo proposto. A Figura 6 mostra, em porcentagem, estas ocorrências. Percebe-se que os fatores localização e valor da diária foram avaliados pela grande maioria dos entrevistados com grau 1 ou 2 de importância, enquanto que os equipamentos e serviços oferecidos, bem como os programas de fidelidade, participam com importância reduzida no processo de escolha, considerando as respostas obtidas.

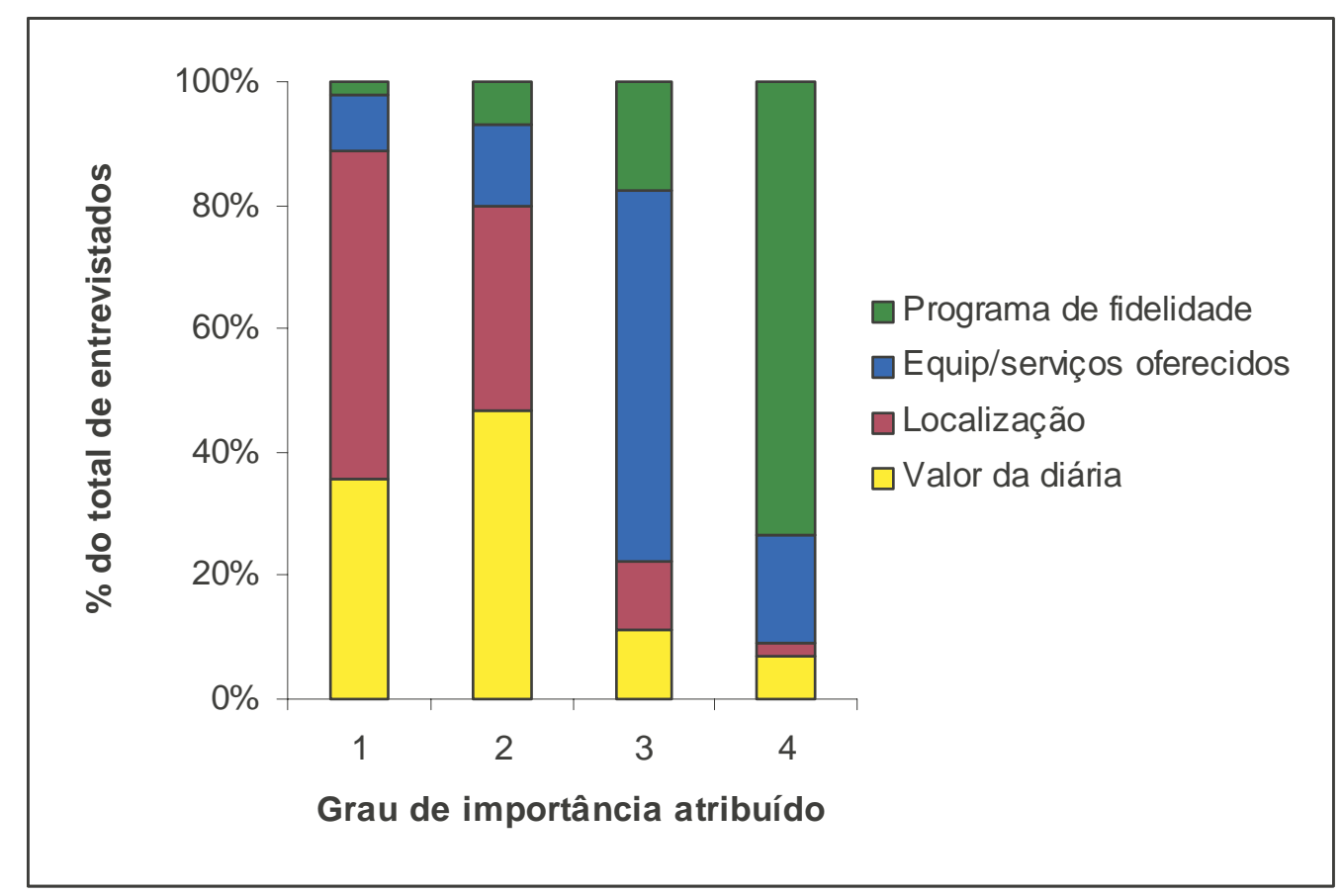

Fig. 6 - Grau de importância dos fatores decisivos para a escolha do hotel

Em uma outra análise desta mesma questão, os intervalos conceituais foram convertidos em intervalos numéricos, assumindo a média das classificações por fator como referência de enquadramento. Assim, considerou-se como fatores muito decisivos aqueles que tiveram média entre 1 e 2 , com poder moderado de influência na decisão aqueles que tiveram média entre 2 e 3 e com baixo poder de influência na decisão aqueles que tiveram média acima de 3. Os resultados podem ser visualizados na Figura 7. 


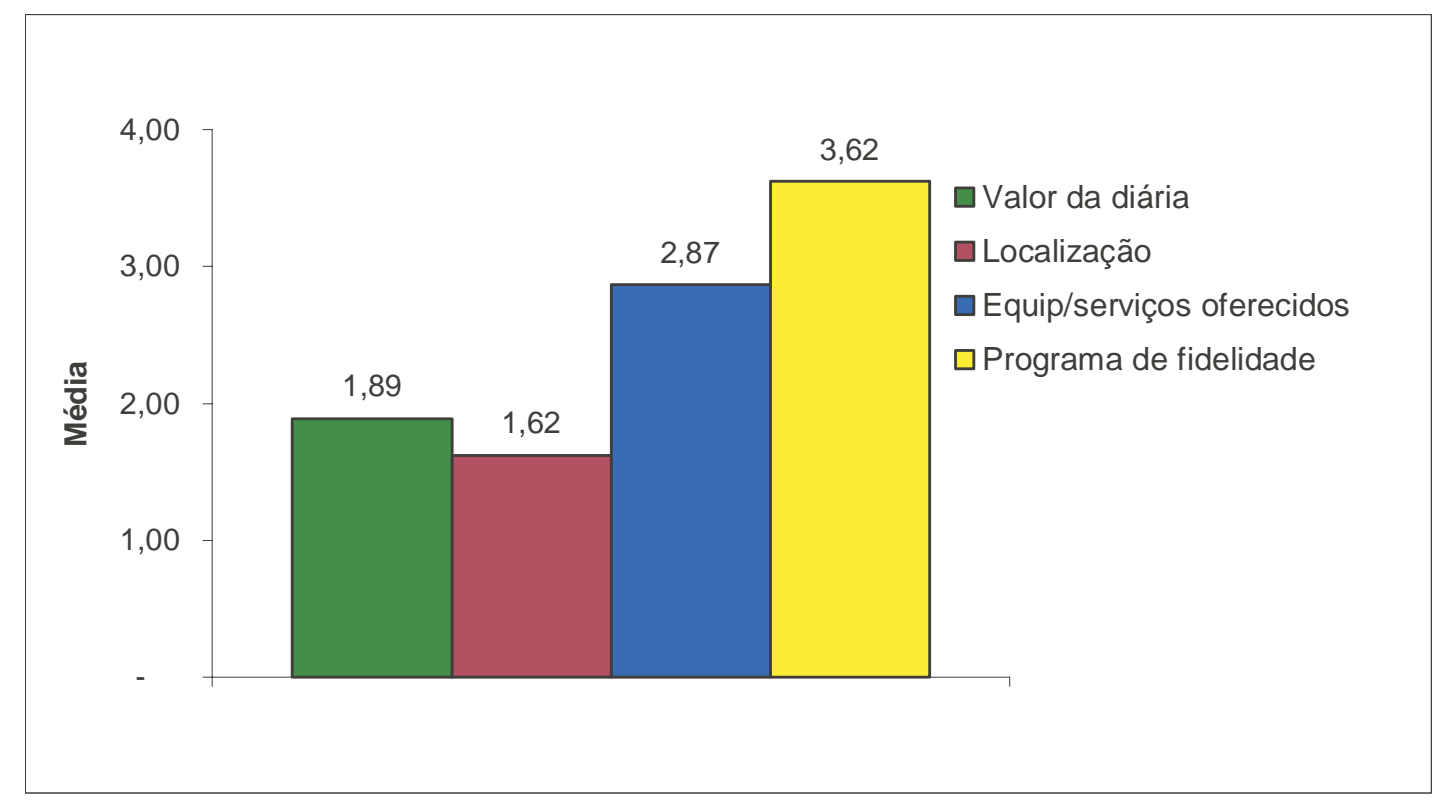

Fig. 7 - Médias dos fatores decisivos para a escolha do hotel

Os resultados obtidos nesta questão são, de certa forma, como seria de se esperar. O valor das diárias e a localização posicionaram-se como fatores muito decisivos na escolha do hotel, enquanto que os equipamentos e serviços oferecidos pelo mesmo revelaram-se com poder moderado de influência na decisão. O programa de fidelidade, ou milhagem/descontos como chamado no questionário, apresentou baixo poder de influência. A localização como fator muito decisivo será discutida frente às respostas obtidas na questão 13 .

\section{Questão 4}

Caso não estivesse em viagem de negócios, consideraria os mesmo fatores acima como decisivos para a escolha do hotel?

Dos questionários respondidos, 54 (70\%) revelaram que pesariam os mesmo fatores na escolha do hotel caso não estivessem em viagem de negócios. Parte-se do princípio então que, para os respondentes, na cidade de São Paulo, os fatores mais decisivos para escolha do hotel independem da motivação da viagem. Porém, as respostas a esta questão podem conter um viés muito importante que é o perfil da 
cidade de São Paulo. Em uma cidade com um trânsito complicado, somado a um alto custo do deslocamento por táxi e com um transporte público deficiente; com opções de lazer a um custo mais elevado do que a maioria, senão a totalidade, das outras capitais do país; e com ausência de grandes belezas naturais, de fato o valor da diária e a localização podem ser fatores importantes na escolha do hotel qualquer que seja a motivação da viagem.

\section{Questão 5}

\section{Qual o meio de transporte que utilizou para chegar à cidade?}

\section{Questão 6}

Qual o meio de transporte que utilizará para se deslocar para suas atividades em São Paulo?

As questões 5 e 6 que seguem foram elaboradas no intuito de sustentar a discussão da questão de número 7. Ao fazer-se a análise das respostas, percebe-se que a grande maioria dos hóspedes que responderam à pesquisa chegaram a São Paulo por via aérea $(84 \%)$ e se utilizam de táxi $(75 \%)$ como meio de transporte para deslocamentos durante sua estadia.

\section{Questão 7}

Quanto à LOCALIZAÇÃO do hotel, favor assinalar 2 (dois) fatores que considera mais importantes:

Os resultados obtidos nesta questão revelam que os fatores proximidade ao local de trabalho e facilidade de acesso foram citados, respectivamente, em $87 \%$ e $49 \%$ das respostas, indicando mais uma vez a influência do trânsito da cidade na escolha do hotel no qual se hospedar. Os resultados podem ser visualizados no Figura 8. A quarta posição obtida pelo fator proximidade ao aeroporto indica que apesar de $84 \%$ dos respondentes terem chegado à cidade por via aérea, este não é um fator de peso considerável quando da escolha da localização do hotel. Tal dado pode estar 
relacionado com a distância e/ou a dificuldade de deslocamento entre o aeroporto e o local de trabalho.

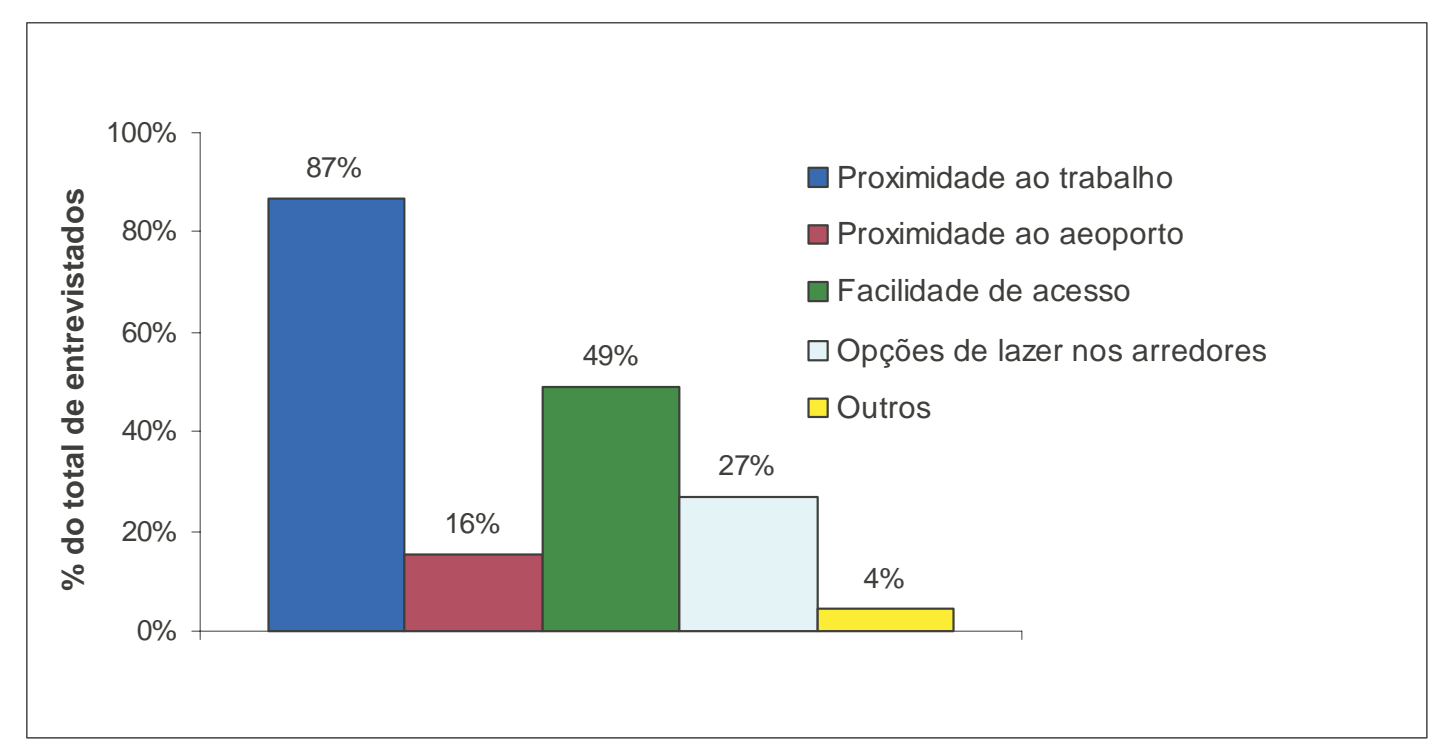

Fig. 8 - Fatores importantes na localização do hotel

\section{Questão 8}

Quanto aos EQUIPAMENTOS/SERVIÇOS, por favor ordene (de 1 a 5), conforme a importância, os equipamentos/serviços que espera encontrar no hotel durante sua permanência:

Há de se sublinhar que, apesar de haver uma lista exaustiva de equipamentos/serviços oferecidos pelos hotéis, buscou-se aqui reuni-los em alguns grupos. Assim como na questão 3, nesta questão os intervalos conceituais foram convertidos em intervalos numéricos, assumindo a média das classificações por fator como referência de enquadramento. Assim, considerou-se como fatores muito importantes aqueles que tiveram média entre 1 e 2,5, com moderada importância aqueles que tiveram média entre 2,5 e 4 e com baixa importância aqueles com média acima de 4. Os resultados podem ser visualizados no Figura 9. 
Entre as cinco alternativas de resposta, observa-se que houve um equilíbrio grande entre três delas: infra-estrutura para lazer, assistência para entretenimento/lazer na cidade e infra-estrutura adequada para realização de eventos. A infra-estrutura para trabalhar e os serviços de apoio mostraram-se como fatores muito importantes para os hóspedes.

Se traçado um paralelo com a questão de número 3, pode-se verificar que apesar dos equipamentos/serviços oferecidos pelo hotel ocuparem apenas a terceira posição em ordem de importância na escolha do hotel, a infra-estrutura para desenvolvimento do trabalho no hotel foi, pelos respondentes, considerado um fator de muita importância dentro do pacote de equipamentos/serviços oferecidos pelo hotel.

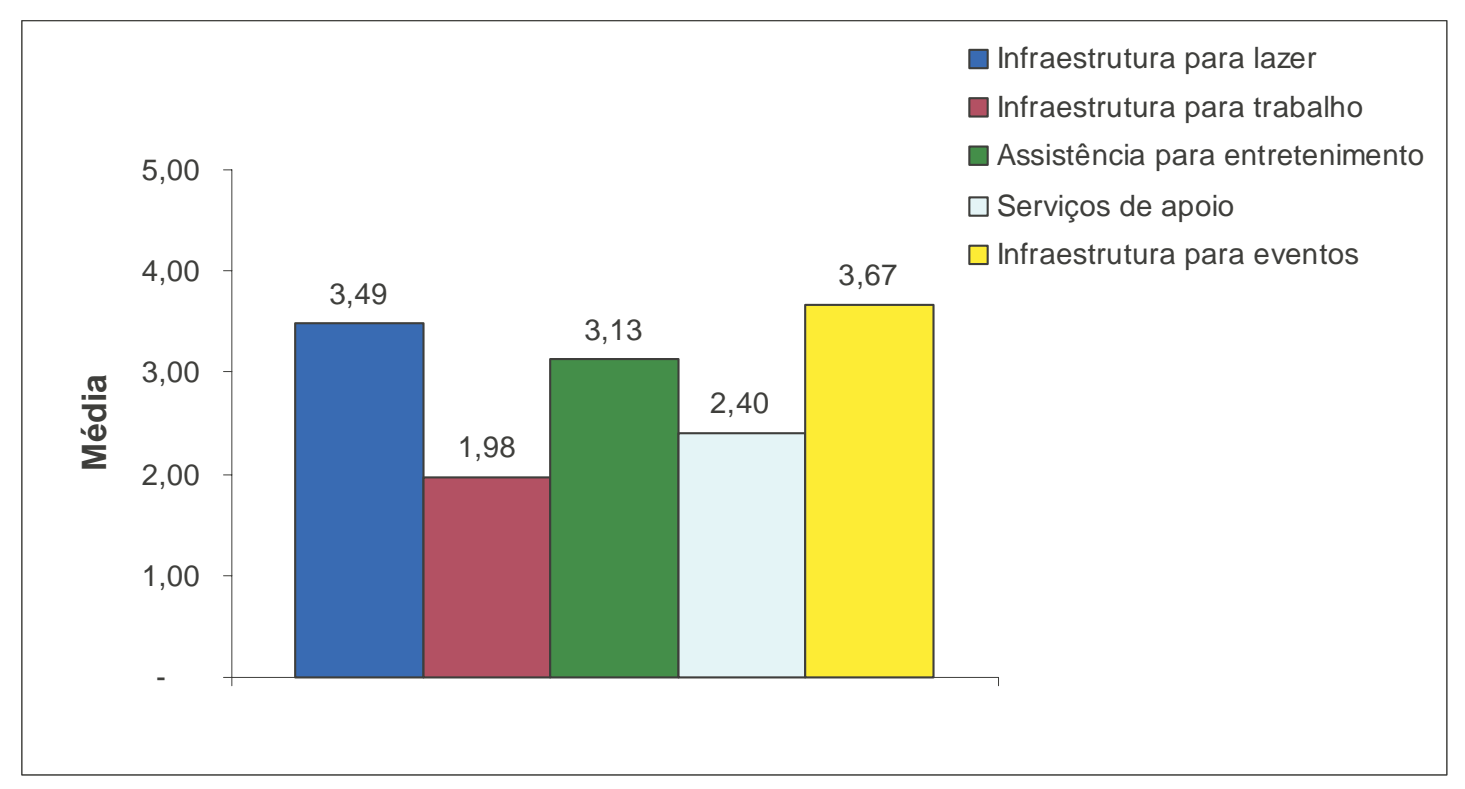

Fig. 9 - Equipamentos/Serviços que espera encontrar no hotel

\section{Questão 9}

Tem como prática usual hospedar-se em diferentes hotéis na cidade de São Paulo enquanto está em viagem de negócios?

Como exposto anteriormente, o principal objetivo desta questão era formar um filtro em conjunto com a questão 1 . 
Houve um certo equilíbrio entre os hóspedes que dizem ter a prática de hospedaremse em hotéis diferentes (41\%) e entre aqueles que dizem ser fiéis ao mesmo hotel (50\%) quando encontram-se na cidade de São Paulo.

As três questões seguintes procuraram sintetizar a percepção dos hóspedes quanto à hospedagem na cidade de São Paulo.

Questão 10

Qual a sua opinião com relação às opções de hospedagem oferecidas pela cidade de São Paulo para as pessoas que estão viajando a negócios?

Duas das quatro opções de resposta a esta questão podem gerar interpretações semelhante. A opção "não pesquiso outras opções além das que utilizo" pode, na verdade, ser interpretada como uma extensão da alternativa "sinto-me confortável com as opções oferecidas", pois é muito provável que um hóspede que se sinta confortável com as opções oferecidas não amplie seus horizontes de pesquisa quanto à hospedagem na cidade.

Todavia, estas duas alternativas, juntas, respondem pela opinião de cerca de $80 \%$ dos respondentes. Os resultados desta questão podem ser visualizados na Figura 10.

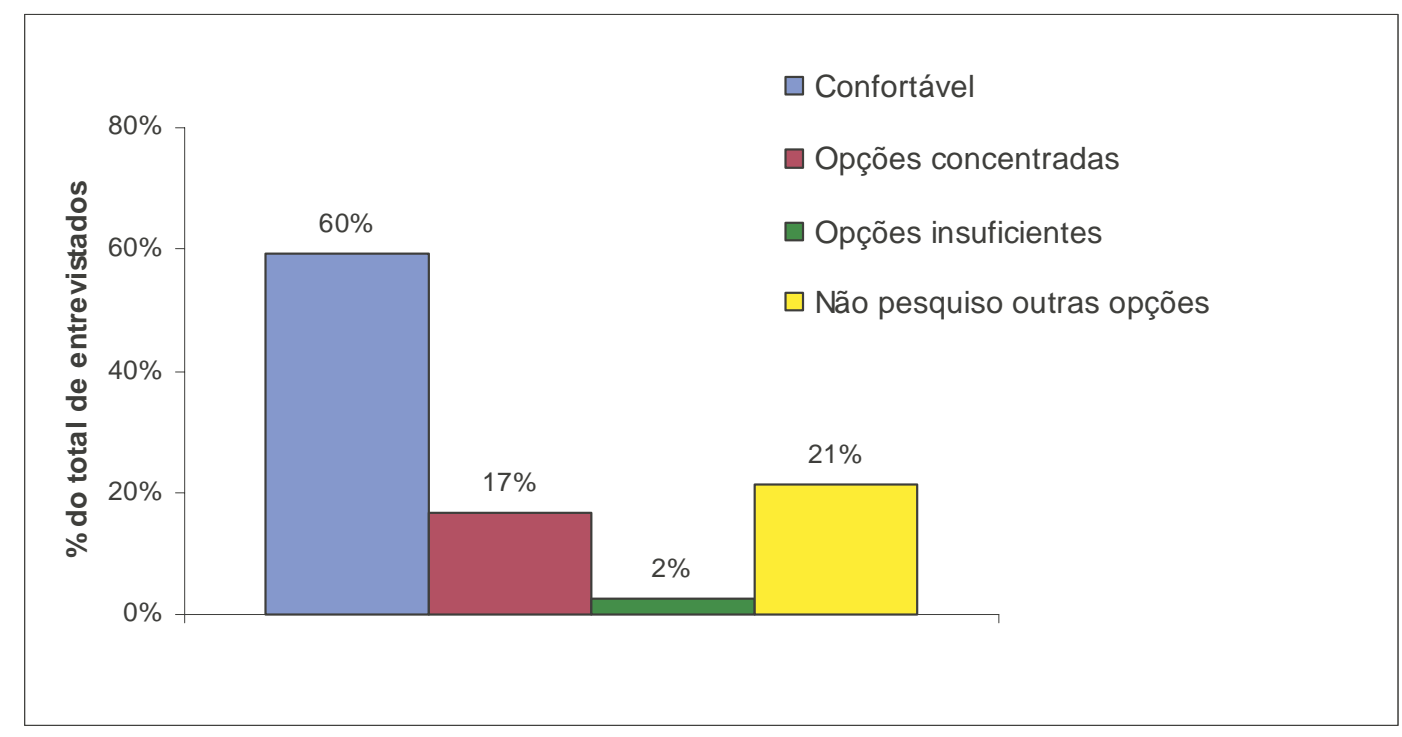


Fig. 10 - Como se sente com as opções de hospedagem em São Paulo

\section{Questão 11}

Por favor, após a análise das alternativas abaixo, assinale os fatores que o(a) motivariam a voltar a este hotel?

As respostas a esta questão acompanham a tendência da questão 3, que considera os fatores decisivos para a escolha do hotel. Maior importância é dada aos fatores valores das diárias e localização, porém, curiosamente, o segundo é considerado mais importante nesta questão 11. Em seguida, da mesma maneira, tem-se os equipamento/serviços e o programa de fidelidade (ou milhagem/descontos). Em absolutamente nenhuma das respostas a alternativa escolhida foi "não tenho a intenção de voltar a este hotel". Esta posição é enfatizada quando se analisa as respostas da questão seguinte.

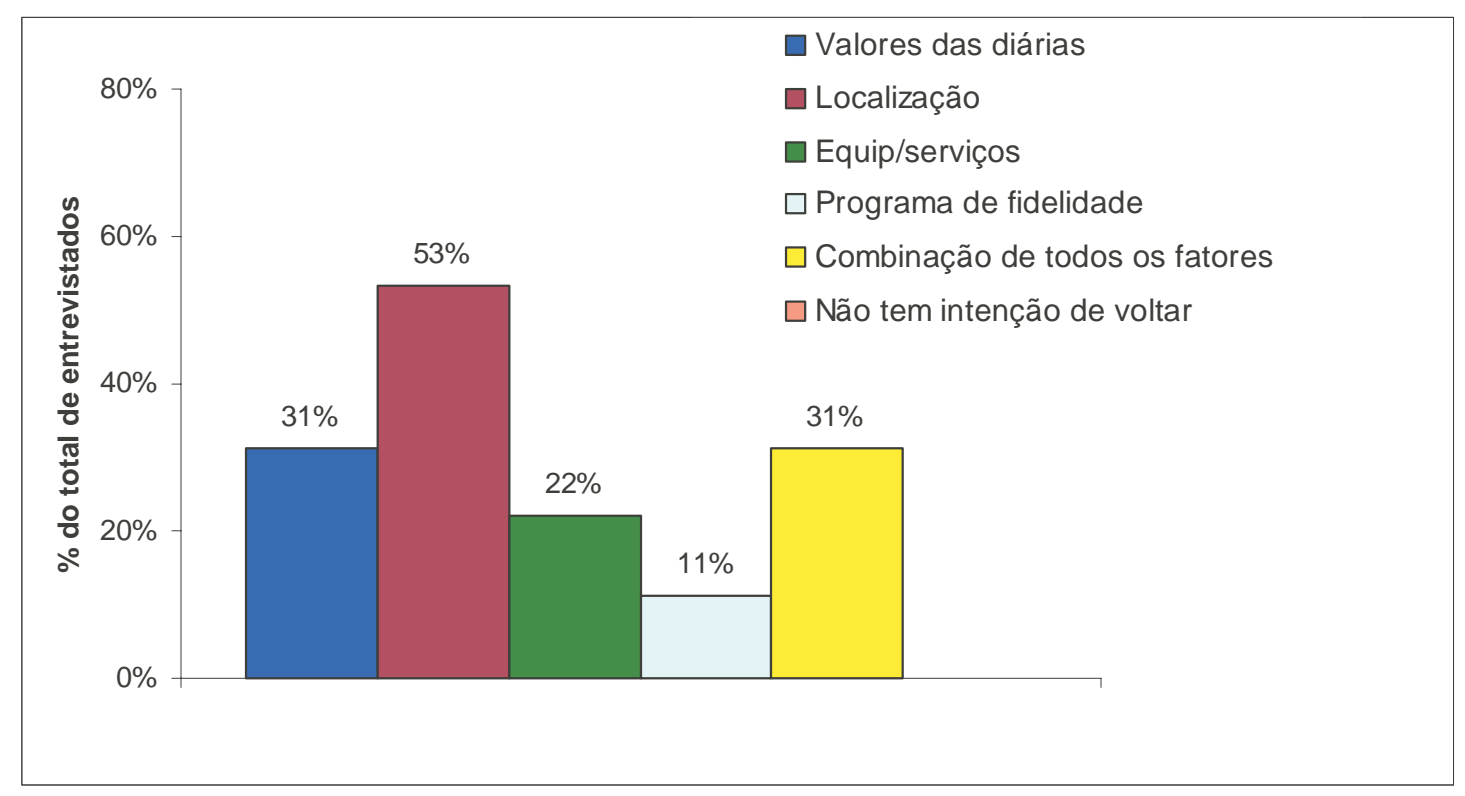

Fig. 11 - Fatores que motivariam a voltar ao hotel

Questão 12 


\section{Qual o seu nível de satisfação com os serviços oferecidos por este hotel?}

Os resultados obtidos oscilaram entre o Muito satisfeito (52\%) e o Satisfeito (48\%). Não houve qualquer resposta que fugisse a estas duas alternativas.

\section{Questão 13}

Na sua opinião, qual o maior problema da cidade de São Paulo no que se refere à hospedagem das pessoas que estão em viagem de negócios?

A questão de número 13 da pesquisa aplicada solicitava ao hóspede que abordasse algum aspecto da cidade a respeito da adequação da hospedagem ao turista de negócios que não houvesse sido incluído no questionário. Apenas 23 dos 79 questionários responderam a esta questão. De um modo geral, as observações podem ser agrupadas em quatro itens principais:

- Problemas com o trânsito da cidade;

- Dificuldades no check-out;

- Falta de opções de lazer no próprio hotel;

- Ausência de conexão rápida à internet (banda larga) nos quartos do hotel.

Porém, o primeiro dos itens anteriores foi o mais citado. O trânsito foi apontado como principal problema por 16 respondentes $(69 \%)$. Este é um fator diretamente relacionado com a infra-estrutura da cidade. Apesar de se constituir um problema geral, que traz grandes prejuízos à cidade, é mais uma fonte de informação importante para que entidades, sindicatos e órgãos municipais passem a tomar medidas no sentido de melhor atender às necessidades do setor turístico da cidade. 


\section{CONSIDERAÇÕES FINAIS}

Retomando alguns aspectos tratados nos capítulos anteriores, entende-se que as empresas e os profissionais necessitam, para o desenvolvimento de suas atividades e negócios, efetuar freqüentes viagens que possibilitem os contatos com pessoas, organismos e empresas, dos quais poderá obter o início, a continuação ou a conclusão de uma atividade ou negócio. O objetivo dessas viagens pode abranger reuniões de trabalho, treinamentos, fechamento de contratos ou participação em eventos, atividades impulsoras de um processo de negócio, sejam para uma empresa ou para um profissional liberal. O conjunto de atividades e operações que esse tipo de cliente realiza pode ser chamado de turismo de negócios.

Pelos elementos e dados discorridos nesta pesquisa pode-se fazer uma avaliação da importância do segmento do turismo de negócios para a economia do país. Trata-se de um segmento que ocupa diversos braços da atividade turística, sejam hotéis, transportes, serviços de apoio, equipamentos de lazer, etc.

O foco deve estar no crescimento da oferta de produtos turísticos adequados e na qualidade exigida para satisfazer as necessidades desses turistas. São profissionais que irão ocupar os equipamentos turísticos como flats e hotéis e que vão usufruir dos serviços da cidade, havendo portanto a necessidade de oferecer produtos que atendam a essa demanda.

$\mathrm{O}$ incremento do turismo de negócios pode contribuir de forma significativa para o crescimento econômico do país. É importante que se dê a esse segmento a atenção necessária para que ele se incremente, destacando-se em qualquer plano turístico nacional ou regional, seja conduzido pela área governamental seja pela privada.

Pode-se, de uma maneira geral, classificar os equipamentos e serviços utilizados pelo turista de negócios em quatro grandes grupos: meios de transporte, hospedagem, locais para eventos e entretenimento/lazer. 
Esta pesquisa procurou esclarecer alguns aspectos relativos à hospedagem, tanto da demanda gerada pelo turismo de negócios como da adequação da oferta hoteleira a este tipo de turista.

O perfil do turista de negócios, no que se refere à hospedagem, parece revelar um hóspede que atribui muita importância às salas de trabalho, aos centros de convenções e aos apartamentos que funcionem como extensão de seu escritório. Porém, esta parece ser apenas parte da realidade.

O estudo exploratório, parte integrante desta pesquisa, tinha justamente como objetivo investigar a percepção deste hóspede com relação à hospedagem, tomandose como cenário a cidade de São Paulo, conhecida como a capital do turismo de negócios da América Latina e centro financeiro do país. A intenção era extrair do turista de negócios quais são os atributos realmente decisivos no processo de escolha do hotel no qual irá se hospedar.

Umas das primeiras conclusões da pesquisa é que os dados disponíveis sobre o verdadeiro perfil das pessoas que visitam a cidade de São Paulo a negócios são insuficientes e indicam uma grande carência de pesquisa nesta área.

Vale ressaltar mais uma vez que o objetivo da pesquisa não foi traçar um perfil do turista de negócios mas sim, a partir da aplicação de um questionário, na cidade de São Paulo, identificar aspectos comuns que indicassem uma tendência de comportamento deste turista com relação à hospedagem.

E a análise dos dados recolhidos na pesquisa de campo revelou alguns resultados de certa forma inesperados.

Entre os respondentes da pesquisa, o conceito do "escritório longe do escritório" é sim um fator de peso na escolha dos equipamentos/serviços que o hotel deve oferecer, porém os valores das diárias e a localização do hotel são preponderantes quando a questão é escolher o hotel onde se hospedar. 
Esta percepção foi enfatizada na questão na qual os hóspedes foram indagados a respeito dos fatores que o motivariam a voltar ao hotel no qual encontravam-se hospedados. Mais uma vez as diárias e a localização do hotel ficaram à frente dos equipamentos/serviços oferecidos pelo hotel.

Outra surpresa nos resultados da pesquisa foi constatar que $70 \%$ dos hóspedes entrevistados tomariam como decisivos para a escolha do hotel os mesmos fatores qualquer que fosse a motivação da viagem. Para esta parcela, não há distinção a fazer nestes fatores de escolha do hotel que dependa dos propósitos de sua permanência na cidade de São Paulo.

Há de se fazer a ressalva de que quanto a escolha da localização do hotel como fator decisivo, a pesquisa conta com a influência de uma característica peculiar de São Paulo: o trânsito. A grande maioria dos respondentes indicou a proximidade do local de trabalho como fator importante na escolha do hotel considerando as dificuldades e o alto custo de deslocamento na cidade. As respostas à única questão aberta do questionário confirmam esta percepção, ao acusarem o trânsito como principal problema da cidade.

Quanto à opinião em relação à oferta hoteleira da cidade de São Paulo, a maioria dos hóspedes se diz confortável com as opções de hospedagem oferecidas e que estão satisfeitos, ou muitos satisfeitos, com os serviços prestados pelos hotéis da cidade.

Os aspectos conceituais revelados pela pesquisa bibliográfica, associados às conjecturas extraídas da coleta de dados do estudo exploratório, levaram à formulação de algumas diretrizes gerais que regem o comportamento do turista de negócios em relação à hospedagem na cidade de São Paulo:

1. Este tipo de hóspede não se mostra disposto a pagar mais pelo oferecimento de equipamentos/serviços diferenciados que atendam as suas necessidades;

2. A proximidade ao local de trabalho é fator importante no processo de escolha do hotel no qual irá se hospedar. O turista de negócios procura evitar situações, tal 
como os congestionamentos, que diminuam o tempo disponível para a realização de suas atividades principais durante a viagem;

3. Entre os hotéis que praticam o mesmo nível de valores de diárias, e que possuam localização estratégica para os hóspedes, levam vantagens aqueles que oferecem, dentre os seus serviços, infra-estrutura adequada para a desenvolvimento do trabalho no próprio hotel.

A proposição apresentada não encerra nenhuma discussão a respeito da percepção do turista de negócios quanto aos atributos decisivos para a escolha do hotel no qual irá se hospedar . Trata-se de uma contribuição para o estudo de um segmento importante para o mercado hoteleiro que, quanto mais conhecido, mais aumentará as chances de incrementos no desempenho do setor.

Espera-se que este trabalho tenha contribuído efetivamente para a formação de uma base conceitual coerente capaz de reduzir a lacuna entre a teoria e a prática do mercado hoteleiro para o turismo de negócios, a partir da compreensão de algumas de suas especificidades, assim como das vantagens que se pode obter com o adequado atendimento ao turista de negócios. 


\section{REFERÊNCIAS BIBLIOGRÁFICAS}

ADTP - Agência de Desenvolvimento Tietê Paraná. Setor de hotéis aquecido. <http://www.adtp.org.br/regiao/r5 06.asp> Acesso em: 19 jan. 2004.

ALBRECHT, K. A única coisa que importa: trazendo o poder do cliente para dentro de sua empresa. São Paulo: Pioneira, 1995.

ALVES, A.J. O planejamento de pesquisas qualitativas em educação. Cadernos de Pesquisa, n.77, p.53-61, 1991.

ANDRADE, J.V. Turismo: fundamentos e dimensões. São Paulo: Ática, 2000.

ANDRADE, N.; BRITO, P.L.; JORGE, W.E. Hotel: planejamento e projeto. São Paulo: Senac, 2000.

ANSARAH, M.G.R. Turismo e segmentação de mercado. São Paulo: Futura, 2002.

AYRES, M. L. A.; DAEMON, I. G.; FERNANDES, P.C.S. Hotel de Negócios. BNDES Setorial, n.8, set. 1998.

BARRETO, M. Manual de iniciação ao estudo do turismo. Campinas: Papirus, 1999.

BENI, M. C. Sistema de turismo - construção de um modelo teórico referencial para aplicação na pesquisa em turismo. 1988. 766 p. Tese (Doutorado) Faculdade de Economia e Administração, Universidade de São Paulo. São Paulo, 1988.

CASTELli, G. Administração hoteleira. Caxias do Sul: Educs, 2001. 
CHIZZOTTI, A. Pesquisa em ciências humanas e sociais. São Paulo: Cortez, 1991.

DEROOS, J. A. Natural occupancy rates and development gaps: a look at the U.S. lodging industry. Cornell Hotel and Restaurant Administration Quarterly, v.40, n.2, p.14-22, Apr. 1999.

DUARTE, V. V. Administração de sistemas hoteleiros. São Paulo: Senac, 2003.

EMBRATUR - Instituto Brasileiro de Turismo. Deliberação Normativa n. 367 de 26 de novembro de 1996. Disponível em: 〈http://www.EMBRATUR.com.br >. Acesso em: 5 fev. 2002a.

Deliberação Normativa n. 429, de 23 de abril de 2002. Disponível em: <http://www.EMBRATUR.com.br >. Acesso em: 01 fev. 2003.

Estudo do mercado interno de turismo 2001. Brasília, 2002 b.

Evolução do turismo no Brasil: 1992-2001. Brasília, 2002c.

ENZ, C. A.; POTTER, G.; SIGUAW, J. A. Serving more segments and offering more products: what are the costs and where are the profits? Cornell Hotel and Restaurant Administration Quarterly, v.40, n.6, p.54-62, Dec. 1999.

ESTUDOS TURÍSTICOS. São Paulo e o turismo de negócios. Disponível em: <http://www.estudosturisticos.com.br/art/bguide002.html> Acesso em: 28 ago. 2002a.

- São Paulo, pólo do turismo de negócios da América Latina. Disponível em: <http://www.estudosturisticos.com.br/art/adtp001.html> Acesso em: 13 jan. 2003. 
- O Turismo de eventos movimenta $\mathrm{R} \$ 37$ bi. Disponível em: <http://www.estudosturisticos.com.br> Acesso em: 28 ago. 2002b.

- O Turismo de negócios no Brasil. Disponível em: <http://www.estudosturisticos.com.br/art/bguide004.html> Acesso em: 28 ago. 2002c.

GALLAGHER, M.; MANSOUR, A. An analysis of hotel real estate market dynamics. Journal of Real Estate Research, v.19, n.2, p.1-31, 2000.

GIANESI, I. G.; CORRÊA, H. L. Administração estratégica de serviços: operações para satisfação do cliente. São Paulo: Atlas, 1996.

GOMES, G.A. Hotelaria: métodos e procedimentos. São Paulo: Intelectom Cultural, 1987.

GUNTHER, H. Como elaborar um questionário: instrumentos psicológicos: manual prático de elaboração. Brasília: UnB, 1999.

HORWATH CONSULTING \& SOTECONTI S/C. A indústria hoteleira brasileira. Anuário. São Paulo, 1998 a 2000.

KLEIN, O. Organização Hoteleira. Caxias do Sul: Educs, 1980.

KOTLER, P. Administração de marketing: análise, planejamento, implementação e controle. São Paulo: Atlas, 1992.

LAGE, B.H.G.; MILONE, P.C. Economia do turismo. São Paulo: Papirus, 2000a.

. Turismo: teoria e prática. São Paulo: Atlas, 2000b. 
MAlHotra, N. K. Pesquisa de marketing: uma orientação aplicada. Porto Alegre: Bookman, 2001.

MATHIESON, A,; WALL, G. Tourism economic, physical and social impacts. New York: Longmam, 1982.

MEDLIK, S.; INGRAM, H. Introdução à hotelaria: gerenciamento e serviços. São Paulo: Campus, 2002.

MERRIT, E. A.; BERGER, F. The value of setting goals. Cornell Hotel and Restaurant Administration Quarterly, v.39, n.1, p.40-49, Feb. 1998.

NORMANN, R. Administração de serviços: estratégia e liderança na empresa de serviços. São Paulo: Atlas, 1993.

OLIVEIRA, A.P. Turismo e desenvolvimento. São Paulo: Atlas, 2000.

PALADINI, E. P. Gestão da qualidade no processo: a qualidade na produção de bens e serviços. São Paulo: Atlas, 1995.

PETROCCHI, M. Hotelaria: planejamento e gestão. São Paulo: Futura, 2002.

PORTER, M. E. Vantagem competitiva. Rio de Janeiro: Campus, 1989.

RICHERS, R.; LIMA, C. P. Segmentação. São Paulo: Nobel, 1991.

SAAB, W. G. L.; GIMENEZ, L. C. P. Flats, apart-hotéis ou hotéis-residência: caracterização e desempenho no Brasil e no município de São Paulo. BNDES Setorial, n.14, set. 2001.

SEADE - Serviço Estadual de Análise de Dados. Disponível em <http://www.seade.gov.br> Acesso em: 15 out. 2002. 
SERSON, F. M. Hotelaria: a busca pela excelência. São Paulo: Cobra, 2000.

SIMPSON, P. M. Segmentação de mercado e mercados-alvo. Porto Alegre: Bookman, 2001.

STAKE, R.E. Pesquisa qualitativa/naturalista: problemas epistemológicos. Educação e Seleção, n.7, jan./jun. 1983.

TOLEDO, G. L. Segmentação de mercado e estratégia de marketing. 1972. 204 p. Tese (Doutorado) - Faculdade de Economia e Administração, Universidade de São Paulo. São Paulo, 1972. 


\section{BIBLIOGRAFIA CONSULTADA}

ASMUSSEN, M.W.; ROCHA, R.M.; MELO JUNIOR, Y.P. O setor hoteleiro em São Paulo: origem, panorama atual e perspectivas de comportamento. Trabalho de conclusão de curso apresentado à Escola Politécnica da Universidade de São Paulo, São Paulo, 2002. Não publicado.

ABIH - Associação Brasileira da Indústria Hoteleira. Disponível em: <http://www.abih.com.br $>$. Acesso em: 5 fev. 2003.

BENI, M.C. Análise estrutural do turismo. São Paulo: Senac, 2000.

BERRIGAN, J.; FINKBEINER, C. Marketing de segmentação. São Paulo: Makron, 1994.

BSH INTERNATIONAL. Disponível em: <http://www.bshinternational.com >. Acesso em: 11 Nov. 2002.

CASTElli, G. Turismo e marketing: uma abordagem hoteleira. Porto Alegre: Sulina, 1994.

DENCKER, A. F. M. Métodos e técnicas de pesquisa em turismo. São Paulo: Futura, 2000.

EMBRATUR - Instituto Brasileiro de Turismo. Deliberação Normativa n. 433, dezembro de 2002. Disponível em: 〈http://www.EMBRATUR.com.br >. Acesso em: 01 fev. 2003.

. Relatório de estudos de demanda turística. Brasília, 1998. 
EMPRESA BRASILEIRA DE ESTUDOS DO PATRIMÔNIO. Disponível em <http://www.embraesp.com.br>. Acesso em: 21 nov. 2002.

ESTADÃO. Disponível em <http://www.estadao.com.br >. Acesso em: 2002 e 2003.

GRAZIADEI, T.M. Turismo de negócios na cidade de Bauru: estudo de caso. 2002. 107 p. Dissertação (Mestrado) - Escola de Comunicações e Artes, Universidade de São Paulo. São Paulo, 2002.

HORWATH \& HORWATH. Hotels of the Future: strategies and action plan. Paris: International Hotel Association, 1988.

HOTEL INVESTMENT ADVISORS. Disponível em <http://www.hia.com.br>. Acesso em: 2002.

KERLINGER, F. N. Metodologia da pesquisa em ciências sociais. São Paulo: E.P.U., 1980.

KNOWLES, T. Hospitality management: an introduction. Londres: Pitman, 1998.

LARA, S. B. Marketing \& vendas na hotelaria. São Paulo: Futura, 2001.

LICKORISH, L.J.; JENKINS, C.L. Introdução ao turismo. Ed. Campus, 2000.

LINCOLN, Y. Collecting and interpreting qualitative materials. Londres: Sage, 1991.

MARTINS, N. P. Novas vertentes da arquitetura hoteleira em São Paulo: o caso dos apart-hotéis. 2000. 3v. Dissertação (Mestrado) - Faculdade de Arquitetura e Urbanismo, Universidade de São Paulo. São Paulo, 2001. 
MATTOS, A.C.; NUNES, A.T.; SANTOVITO, R.F. Análise setorial do mercado de hospedagem na cidade de São Paulo. Trabalho de conclusão de curso apresentado à Escola Politécnica da Universidade de São Paulo, São Paulo, 2001. Não publicado.

PIMENTA, C.; RICHERS,R. Segmentação: opção estratégica para o mercado brasileiro. São Paulo: Nobel, 1991.

ROCHA LIMA JÚNIOR, J. Arbitragem de valor de hotéis. Boletim Técnico BT/PCC/267. São Paulo: EPUSP, 2000.

Princípios para análise da qualidade de empreendimentos: o caso dos empreendimentos da base imobiliária. Boletim Técnico BT/PCC/153. São Paulo: EPUSP, 1995.

SENAC. Turismo, hotelaria, gastronomia \& outros, núcleo de comunicação e informação. Clipping, n. 83/85, fev./mar. 1999.

SINDICATO DAS EMPRESAS DE COMPRA, VENDA, LOCAÇÃO E ADMINISTRAÇÃO DE IMÓVEIS COMERCIAIS E RESIDENCIAIS DE SÃO PAULO. Disponível em <http:// www.secovi-sp.com.br> . Acesso em: 17 maio 2002.

SMITH, R.A.; LESURE, J.D. The U.S. lodging industry today. Cornell Hotel and Restaurant Administration Quarterly, v.40, n.1, p.18-25, Feb. 1999.

TUCH, D.L. Dimensionamento da área do hotel. São Paulo: Senac, 1994.

. Estudo de viabilidade para implantação de hotéis. São Paulo: Senac, 1983. 
WANDERLEY, H.; OLIVEIRA, N.G. O mercado de escritórios em edifícios na cidade de São Paulo: histórico e perspectivas. Trabalho de conclusão de curso apresentado à Escola Politécnica da Universidade de São Paulo, São Paulo, 2001. Não publicado.

WEBER, K. Meeting planner's perceptions of hotel-chain pratices and benefits. Cornell Hotel and Restaurant Administration Quarterly, p.32-38, Aug. 2000.

WEINSTEIN, A. Segmentação de mercado. São Paulo: Atlas, 1995. 
ANEXO A: Questionário aplicado aos hóspedes nos hotéis 


\section{PESQUISA - HOTÉIS DE NEGÓCIOS NA CIDADE DE SÃo PAULO}

Este questionário deverá ser respondido apenas por pessoas cujo propósito da viagem seja a realização de contatos, negócios ou desenvolvimento profissional.

1. Quantas vezes esteve na cidade de São Paulo anteriormente?
( ) é a primeira vez
( ) até 5 vezes
( ) mais de 5 vezes

2. Quanto tempo permaneceu ou pretende permanecer na cidade?
( ) 1 dia
( ) 2 dias
( ) 3 dias
( ) mais de 3 dias

3. Por favor, ordene (de 1 a 4), conforme a importância, os fatores que considera decisivos para a escolha do hotel no qual irá se hospedar:

(1) Muito importante (4) Pouco importante

( ) valor da diária

( ) equipamentos/serviços oferecidos

( ) localização

( ) programa de milhagem e/ou descontos

4. Caso não estivesse em viagem de negócios, consideraria os mesmos fatores acima como decisivos para a escolha do hotel?
( ) $\operatorname{sim}$
( ) não

5. Qual o meio de transporte que utilizou para chegar à cidade?
( ) avião
( ) ônibus
( ) automóvel
( ) outros (por favor especifique)

6. Qual meio de transporte utilizará para se deslocar para suas atividades em São Paulo?
( ) táxi
( ) automóvel próprio
( ) automóvel alugado

( ) ônibus

( ) outro (por favor especifique) 
7. Quanto à LOCALIZAÇÃO do hotel, favor assinalar 2 (dois) fatores que considera mais importantes:

( ) proximidade ao local de trabalho

( ) opções de lazer nos arredores

( ) proximidade ao aeroporto

( ) facilidade de acesso

( ) outra (por favor especifique)

8. Quanto aos EQUIPAMENTOS/SERVIÇOS, por favor ordene (de 1 a 5), conforme a importância, os serviços/equipamentos que espera encontrar no hotel durante sua permanência:

(1) Muito importante (5) Pouco importante

( ) infra-estrutura para lazer

( ) infra-estrutura para trabalhar (escritórios temporários)

( ) assistência para entretenimento/lazer na cidade

( ) serviços de apoio (lavanderia, barbearia, loja de conveniência,etc.)

( ) infra-estrutura adequada para a realização de eventos

9. Tem como prática usual hospedar-se em diferentes hotéis na cidade de São Paulo enquanto está em viagem de negócios?
( ) $\operatorname{sim}$
( ) não
( ) é a primeira vez

10. Qual a sua opinião com relação às opções de hospedagem oferecidas pela cidade de São Paulo para as pessoas que estão viajando a negócios?

( ) sinto-me confortável com as opções oferecidas

( ) as opções encontram-se concentradas em poucas regiões da cidade

( ) as opções são em número insuficiente

( ) não pesquiso outras opções além das que utilizo

11. Por favor, após a análise das alternativas abaixo, assinale os fatores que o(a) motivariam a voltar a este hotel:

( ) os valores das diárias

( ) a localização

( ) o oferecimento dos equipamentos/serviços apontados anteriormente

( ) programa de milhagem e/ou descontos

( ) a combinação de todos os fatores acima

( ) não tenho a intenção de voltar a este hotel 
12. Qual o seu nível de satisfação com os serviços oferecidos por este hotel?
( ) Muito satisfeito
( ) Satisfeito
( ) Pouco satisfeito
( ) Insatisfeito (por favor justifique)

13. Na sua opinião, qual o maior problema da cidade de São Paulo no que se refere à hospedagem das pessoas que estão em viagem de negócios? 
ANEXO B: Questionário aplicado via $e$-mail 
Este questionário deverá ser respondido apenas por pessoas cujo propósito da viagem seja a realização de contatos, negócios ou desenvolvimento profissional.

o espaço em azul indica os campos editáveis

Por favor, escreva o nome e o bairro do hotel onde encontra-se hospedado

Hotel:

Bairro:

1. Quantas vezes esteve na cidade de São Paulo anteriormente ? (assinale com um $\mathrm{x}$ )

\begin{tabular}{|l|l}
\hline é a primeira vez \\
até 5 vezes \\
mais de 5 vezes
\end{tabular}

2. Quanto tempo permaneceu ou pretende permanecer na cidade ? (assinale com um $\mathrm{x}$ )

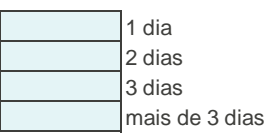

3. Por favor, ordene (de 1 a 4), conforme a importância, os fatores que considera decisivos para a escolha do hotel no qual irá se hospedar quando viaja a São Paulo:

1 Muito importante

4 Pouco importante

\begin{tabular}{|l|l}
\hline & valor da diária \\
localização \\
equipamentos/serviços oferecidos
\end{tabular}

4. Caso não estivesse em viagem de negócios, consideraria os mesmos fatores acima como decisivos para a escolha do hotel? (assinale com um $\mathbf{x}$ )

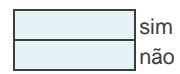

5. Qual o meio de transporte que utilizou para chegar à cidade? (assinale com um $\mathrm{x}$ )

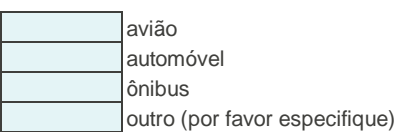

6. Qual meio de transporte utilizará para se deslocar para suas atividades em São Paulo? (assinale com um $\mathrm{x}$ )

\begin{tabular}{|l|l|}
\hline & táxi \\
\hline & automóvel próprio \\
& automóvel alugado \\
\hline & onibus \\
& outro (por favor especifique)
\end{tabular}

7. Quanto à LOCALIZAÇÃO do hotel, favor assinalar 2 (dois) fatores que considera mais importantes: (assinale com um $\mathrm{x}$ )

\begin{tabular}{|l|l|}
\hline & proximidade ao local de trabalho \\
proximidade ao aeroporto \\
facilidade de acesso \\
opções de lazer nos arredores \\
outra (por favor especifique)
\end{tabular}

8. Quanto aos EQUIPAMENTOS/SERVIÇOS, por favor ordene (de 1 a 5), conforme a importância, os serviços/equipamentos que espera encontrar no hotel durante sua permanência:

$1 \quad$ Muito importante

5 Pouco importante

\begin{tabular}{|l|l}
\hline & infra-estrutura para lazer \\
\hline infra-estrutura para trabalhar (escritórios temporários) \\
assistência para entretenimento/lazer na cidade \\
serviços de apoio (lavanderia, barbearia, loja de conveniência,etc.) \\
infra-estrutura adequada para a realização de eventos
\end{tabular}

9. Tem como prática usual hospedar-se em diferentes hotéis na cidade de São Paulo enquanto está em viagem de negócios? (assinale com um $\mathrm{x}$ )

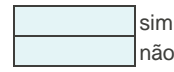


é a primeira vez

10. Qual a sua opinião com relação às opções de hospedagem oferecidas pela cidade de São Paulo para as pessoas que estão viajando a negócios? (assinale com um $\mathrm{x}$ )

\begin{tabular}{|l|l|l}
\hline & $\begin{array}{l}\text { sinto-me confortável com as opções oferecidas } \\
\text { as opções encontram-se concentradas em poucas regiões da cidade } \\
\text { as opções são em número insuficiente } \\
\text { não pesquiso outras opções além das que utilizo }\end{array}$
\end{tabular}

11. Por favor, após a análise das alternativas abaixo, assinale os fatores que o(a) motivariam a voltar ao hotel no qual está hospedado: (assinale com um $\mathrm{x}$ )

\begin{tabular}{|l|l|l|l}
\hline & os valores das diárias \\
a localização \\
o oferecimento dos equipamentos/serviços apontados anteriormente \\
programa de milhagem e/ou descontos \\
a combinação de todos os fatores acima \\
não tenho a intenção de voltar a este hotel
\end{tabular}

12. Qual o seu nível de satisfação com os serviços oferecidos pelo hotel no qual está hospedado? (assinale com um $\mathrm{x}$ )

\begin{tabular}{|l|l|}
\hline & muito satisfeito \\
\hline & satisfeito \\
\hline & pouco satisfeito \\
\hline insatisfeito (por favor justifique)
\end{tabular}

13. Na sua opinião, qual o maior problema da cidade de São Paulo no que se refere à hospedagem das pessoas que estão em viagem de negócios? 